\title{
AVALIAÇÃO MICROSCÓPICA DA RESPOSTA TECIDUAL DE CAVIDADES CIRÚRGICAS EM FÊMURES DE COELHO PREENCHIDAS COM SULFATO DE CÁLCIO
}

\section{SERGIO TOSHINORI MAEDA}

Tese apresentada à Faculdade de Odontologia de Bauru da Universidade de São Paulo, como parte dos requisitos para obtenção do título de Doutor, em Odontologia, na área de Endodontia.

(Edição Revisada)

\section{Bauru}




\section{AVALIAÇÃO MICROSCÓPICA DA RESPOSTA TECIDUAL DE CAVIDADES CIRÚRGICAS EM FÊMURES DE COELHO PREENCHIDAS COM SULFATO DE CÁLCIO}

\section{SERGIO TOSHINORI MAEDA}

Tese apresentada à Faculdade de Odontologia de Bauru da Universidade de São Paulo, como parte dos requisitos para obtenção do título de Doutor, em Odontologia, na área de Endodontia.

(Edição Revisada)

Orientador: Prof. Dr. Clóvis Monteiro Bramante Co-Orientador: Prof. Dr. Rumio Taga

\section{Bauru}


Maeda, Sérgio Toshinori
M268a Avaliação microscópica da resposta tecidual de cavidades cirúrgicas em fêmures de coelho preenchidas com sulfato de cálcio / Sérgio Toshinori Maeda. -- Bauru, 2005.

xxix, 97 p. : il. ; $30 \mathrm{~cm}$.

Tese (Doutorado) -- Faculdade de Odontologia de Bauru. Universidade de São Paulo.

Orientador: Prof. Dr. Clóvis Monteiro Bramante Co-Orientador: Prof. Dr. Rumio Taga

Autorizo, exclusivamente pra fins acadêmicos e científicos, a reprodução total ou parcial desta tese, por processo fotocopiadores oe/ou meios eletrônicos.

Assinatura do autor:

Data:

Comitê de Ética da FOB-USP

Projeto de Pesquisa desenvolvido no período de 2001-2002, quando o Comitê de Ética da FOB-USP não tinha sido implantado. Ofício de 22/10/2004. 
Dados Curriculares 


\section{SERGIO TOSHINORI MAEDA}

08 de fevereiro de 1946

Bastos, SP

Toshikazu Maeda

Akiko Maeda

$1966-1969$

$1974-1975$

$1975-1976$

$1979-2005$

$1992-1996$

$1996-2005$

$2000-2004$

Associações
Nascimento

Filiação

Curso de Graduação em Odontologia na Faculdade de Odontologia de Bauru da Universidade de São Paulo

Estágio na Disciplina de Endodontia da Faculdade de Odontologia da USP

Curso de Especialização em Endodontia promovido pela Faculdade de Odontologia de Araraquara - UNESP

Professor adjunto da Disciplina de Endodontia da Faculdade de Odontologia da Universidade Metodista de São Paulo - UMESP

Curso de Pós-Graduação em Endodontia, em nível de Mestrado, na Faculdade de Odontologia da Universidade Metodista de São Paulo - UMESP

Coordenador do Curso de Especialização em Endodontia pela Associação Paulista de Cirurgiões Dentistas Regional de São Bernardo do Campo, SP - APCD-SBC

Curso de Pós-Graduação em Endodontia, em nível de Doutorado, na Faculdade de Odontologia de Bauru da Universidade de São Paulo

Conselho Regional de Odontologia de São Paulo - CRO-SP

Associação Paulista de Cirurgiões Dentistas - APCD 
Dedicatória

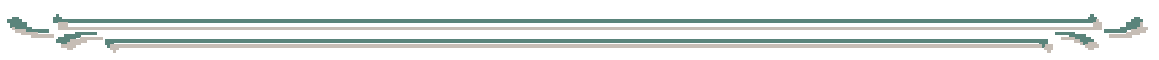




\section{Agradeço a Deus, ser supremo, por ter me concedido a sabedoria, o discernimento e a compreensão}

para os pequenos e grandes adventos da vida.

"Tudo isto inquiri com sabedoria; e disse: Sabedoria adquirirei; mas ela ainda estava longe de mim." Eclesiastes: $7: 25$ 


\section{DEDICO ESTE TRABALHO:}

\section{À Harumi}

pelo que representa em minha vida, como esposa e exemplo marcante de mãe dedicada, pelo incentivo constante e apoio nunca negados.

Carinhosamente, aos meus filhos:

\section{Sergio Henrique, Priscilla e Henry,}

por serem maravilhosos e compreenderem a minha ausência física em muitas ocasiões; a quem tenho sempre no coração, com grande ternura.

Aos meus pais:

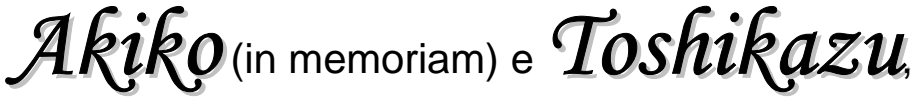

pela sabedoria e discernimento com que conduziram minha educação, pelo exemplo indiscutível de caráter e integridade, pelo amor que sempre esteve presente, de forma real e muito sincera. 
Agradecimentos 


\section{AGRADECIMENTOS ESPECIAIS}

Ao meu Orientador,

\section{Prof. Dr. Clóvis Monteiro Bramante,}

pelo seu exemplo de humanidade e dedicação,

pela sua perfeição como cientista,

nos orientando com segurança de um sábio,

a disponibilidade de um mestre e a confiança de um amigo.

Meu respeito e admiração

O meu muitíssimo obrigado!!! 
Ao professor Co-Orientador:

\section{Prof. Dr. Rumio Taga,}

cuja vida reflete a história daqueles que fizeram da docência uma missão, abrindo as portas do Departamento de Histologia e me acolhendo entre os seus;

com presteza e competência orientando a análise histológica, transmitindo conhecimentos que permitiram a concretização deste trabalho. Meu reconhecimento e gratidão!!! 
Ao Prof. Dr. Alceu Berbert, meu primeiro mestre de Endodontia, grande incentivador da minha carreira de docente, fonte de sabedoria e paciência. Minha admiração pela sua competência e dedicação.

Aos professores do Departamento de Endodontia da Faculdade de Odontologia de Bauru da Universidade de São Paulo

\section{Prof. Dr. Norberti Bernadinelli$$
\text { Prof. Dr. Roberto Brandão Garcia }
$$$$
\text { Prof. Dr. Ivaldo Gomes }
$$

Pelos ensinamentos recebidos, orientação científica precisa e constante incentivo;

Aos funcionários do Departamento de Endodontia da Faculdade de Odontologia de Bauru da Universidade de São Paulo, Sueli, Neide e Patrícia, pela amizade e colaboração em todos momentos; e em especial ao Sr. Edimauro pela ajuda inestimável e pronta colaboração nos momentos difíceis;

A bióloga e técnica do Departamento de Histologia da Faculdade de Odontologia de Bauru da Universidade de São Paulo, Tânia Cestari, que com presteza e competência orientou a análise histológica das lâminas, transmitindo conhecimentos que permitiram a concretização deste trabalho.

A Daniela, bióloga e técnica do laboratório do Departamento de Histologia da Faculdade de Odontologia de Bauru da Universidade de São Paulo, pela valiosa contribuição na inclusão das peças, corte e coloração. 
A todos os professores e servidores do Departamento de Bioquímica da Faculdade de Odontologia de Bauru da Universidade de São Paulo, representada pelo Prof. Dr. Eulázio Mikio Taga, pela ajuda, confiança e orientações oportunas.

Aos servidores do Biotério Central da Faculdade de Odontologia de Bauru da Universidade de São Paulo, na pessoa do biólogo, Sr. Luis Carlos da Silva, pelo dedicado profissionalismo e inestimável ajuda no trato com os animais deste experimento.

As bibliotecárias e demais funcionários da Biblioteca da Faculdade de Odontologia de Bauru da Universidade de São Paulo, pelo convívio harmonioso e dedicação; em especial a Sra. Rita de Cássia Paglione, pela atenção, cordialidade e carinho sempre demonstrados.

Aos meus amigos da turma de Doutorado:

Carlos Herrera, Carlos Henrique, Christian, Fabiana, Flaviana, Luciana, Patrícia e Vânia. 


\section{AGRADECIMENTOS INSTITUCIONAIS}

À direção da Faculdade de Odontologia de Bauru da Universidade de São Paulo, na pessoa da Diretora Profa. Dra. Maria Fidela de Lima Navarro, pela recepção e pelas condições oferecidas para o desenvolvimento deste trabalho.

À Comissão de Pós-Graduação da Faculdade de Odontologia de Bauru da Universidade de São Paulo, na pessoa do Presidente Prof. Dr. José Carlos Pereira.

A todos os Professores do corpo docente do curso de Pós-Graduação, Doutorado em Endodontia da Faculdade de Odontologia de Bauru da Universidade de São Paulo, pelos valiosos ensinamentos, dedicação e amizade.

À direção da Faculdade de Odontologia da Universidade Metodista de São Paulo, na pessoa do Diretor Prof. Dr. Savério Mandetta, pelo incentivo e apoio à docência.

À Disciplina de Endodontia da Faculdade de Odontologia da Universidade Metodista de São Paulo na pessoa do Prof. Dr. Marcio Braga Lauretti, exemplo de dignidade, honestidade e competência, pelo valioso convívio e pela transmissão de experiências. 


\section{AGRADECIMENTOS PESSOAIS}

Aos amigos e companheiros da Disciplina de Endodontia da Faculdade de Odontologia da Universidade Metodista de São Paulo:

Adriana Paisano, Luis Marcos Mansi, José Lauriére Horta Guimarães, Margarida Odete Paes, Kleber Kildare Teodoro de Carvalho e Sergio Koiti Kamei pelo convívio fraterno, respeito, amizade e união.

As amigas Kátia Crateschini da Silva e Priscilla Fidelis Carvalho, pela ajuda incansável no manejo com os animais na parte laboratorial.

Ao Prof. Dr. Carlos Henrique, pela amizade, companheirismo e muitas trocas de conhecimentos.

A $\mathcal{M E R C K}$ do $\mathfrak{B r a s i}$, pelo apoio e incentivo, cedendo gentilmente o material para a pesquisa.

A Srta. Noemia, bibliotecária da Universidade Metodista de São Paulo, pela ajuda e competência.

A química, Sra. Márcia Arraes, pelas sugestões e trocas de conhecimentos. 
A Srta. Ana Cecília Água de Melo, pela revisão final da redação.

Ao Sr. Marcelo Cardoso Freitas Gonçalves, pela formatação e organização final deste trabalho.

O desenvolvimento deste trabalho foi possível graças à colaboração e ajuda de várias pessoas. A todos vocês meus agradecimentos!!! 
Sumário

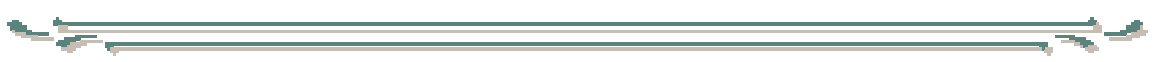




\section{SUMÁRIO}

LISTA DE FIGURAS ……..........................................................

LISTA DE QUADRO ……............................................................ x xiv

LISTA DE ABREVIATURAS E SÍMBOLOS ..................................... xxvi

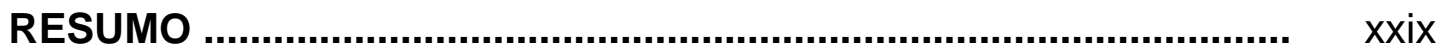

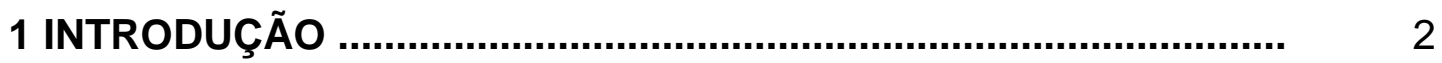

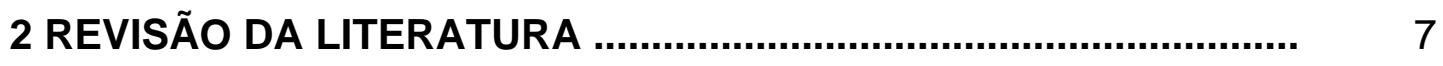

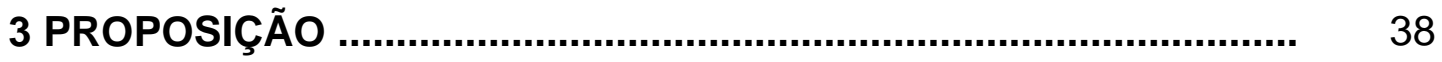

4 MATERIAL E MÉTODOS …....................................................... 40

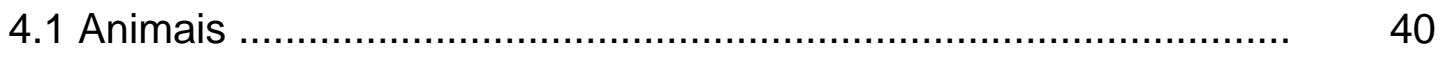

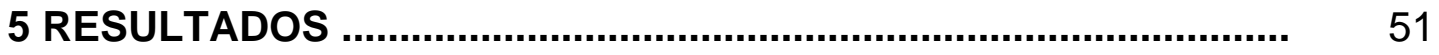

5.1 Análise Morfológica …………............................................... 51

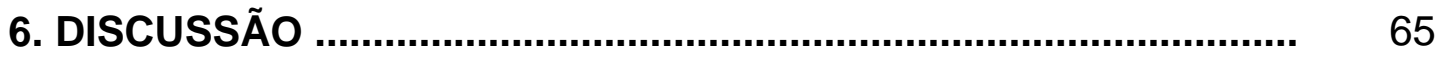

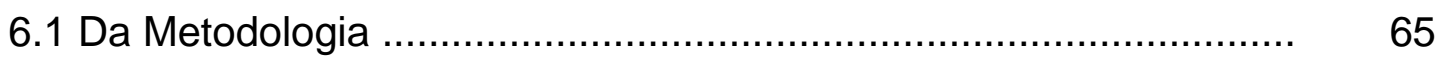

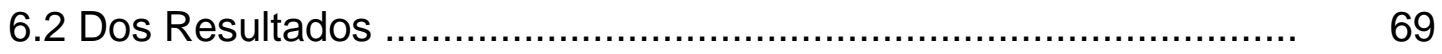

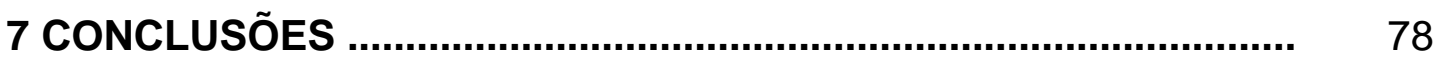

REFERÊNCIAS BIBLIOGRÁFICAS ..............................................

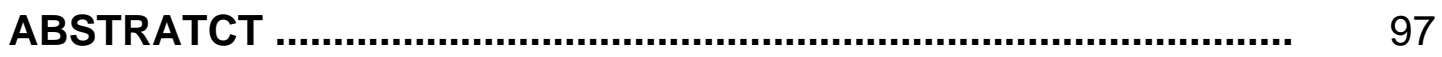

APÊNDICE 


\section{Lista de Figuras}

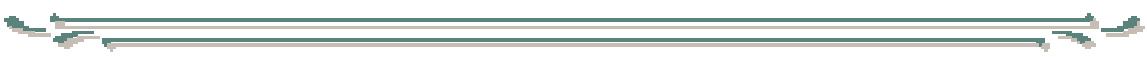




\section{LISTA DE FIGURAS}

FIGURA 1 - Trefina n. 3 da Dentoflex, para confecção da cavidade cirúrgica

FIGURA 2 - Local das duas cavidades cirúrgicas

FIGURA 3 - Sulfato de cálcio di-hidratado da Merck do Brasil

FIGURA 4 - Apresentação comercial do Capset

FIGURA 5 - Apresentação comercial do Surgiplaster

FIGURA 6 - Recipiente contendo sangue e o sulfato de cálcio

FIGURA 7 - Porta enxerto adaptado, com o sulfato de cálcio, para ser inserido à cavidade

FIGURA 8 - Cavidade cirúrgica preenchida com o sulfato de cálcio ....

FIGURA 9 - Sutura interna (Vicryl)

FIGURA 10 - Sutura externa Ethicon n. ${ }^{\circ} 4.0$ (seda)

FIGURA 11 - Defeito ósseo preenchido por coágulo sangüíneo, 30 dias pós cirurgia. a) visão panorâmica do defeito exibindo formação de tecido ósseo(asterisco) e mielóide(M) na superfície periostal voltada à derme em forma de calo e pouca formação óssea(setas) na área entre as bordas(B). b) Detalhe do calo ósseo da figura anterior(área retangular) exibindo tecido ósseo primário neoformado (asterisco) e tecido mielóide entre a superfície do defeito e o periósteo (seta vazada). c) visão panorâmica da parte inferior do defeito voltado para o canal medular exibindo formação de tecido ósseo de arranjo trabecular (setas) e mais internamente de tecido conjuntivo (TC); d) detalhe da figura anterior (área retangular), com as trabéculas ósseas (setas) e o tecido conjuntivo (TC). e) maior aumento do osso neoformado (seta) e o tecido mielóide (M); f) defeito com fechamento por tecido ósseo primário entrelaçado (arranjo trabecular) (asterisco) de espessura próxima ao da borda do defeito (B) já remodelando para tecido ósseo compacto, recoberto pelo periósteo (seta vazada) 
FIGURA 12 - Defeito ósseo preenchido pro Surgiplaster, 30 dias póscirurgia: a) visão panorâmica exibindo duas finas faixas de tecido ósseo (seta vazada), sendo a externa contínua e a interna fragmentada, e no espaço entre as duas, presença de tecido conjuntivo sendo substituído por tecido mielóide (estrela). B-c) detalhes da figura anterior exibindo a borda óssea, a s duas faixas de tecido ósseo neoformado (seta vazada), tecido conjuntivo e mielóide (estrela) e traves ósseas (setas); d) pequenas formações ósseas (setas) envoltas por tecido rico em células e vasos sangüíneos (estrela)

FIGURA 13 - Defeito ósseo preenchido por Capset, 30 dias póscirurgia mostrando a região central invadida por tecido conjuntivo: a) visão panorâmica do defeito exibindo formação de osso primário com arranjo (entrelaçado) trabeculado (setas) a partir da borda do defeito(B) em direção ao canal medular e na região central por tecido conjuntivo(TC); b) detalhe da figura anterior (área retangular) do tecido ósseo neoformado (seta) associado a borda óssea(B); c) região central do defeito, tecido ósseo neoformado (setas) e uma área central perpendicular preenchido pro tecido conjuntivo (TC); d) detalhe do tecido ósseo neoformado (setas) e o tecido conjuntivo entre as trabéculas (TC)

FIGURA 14 - Defeito ósseo preenchido por Capset 30 dias pós cirurgia: $a-b)$ defeito apresentando preenchimento por tecido ósseo (setas) com trabéculas finas e esparsas exibindo abundante tecido conjuntivo (TC) nos espaços inter trabeculares; c-d) detalhe da formação de tecido ósseo (setas) associado ou não a borda óssea (B) e tecido conjuntivo fibroso (TC) 
FIGURA 15 - Defeito ósseo preenchido por Merck, 30 dias póscirurgia: a) visão panorâmica da formação óssea (seta) a partir da borda do defeito (B) em direção ao canal medular (CM) e na região central do defeito uma depressão resultante da invaginação do tecido conjuntivo fibroso (TC) de recobrimento externo.; b) detalhe da formação óssea (seta) associada a borda do defeito (B); c) detalhe da formação óssea (seta) e da invaginação do tecido conjuntivo (TC) para o canal medular (CM); d) aspecto do tecido ósseo neoformado com os espaços entre as trabéculas preenchidos por tecido conjuntivo (TC); e) visão panorâmica do defeito em que ocorreu o preenchimento por tecido conjuntivo fibroso (TC) fazendo saliência para o canal medular com formação de tecido ósseo neoformado (seta) à partir da borda óssea (B) e o tecido conjuntivo fibroso (TC) ...

FIGURA 16 - Defeito ósseo preenchido com coágulo sangüíneo, 60 dias pós-cirurgia: a) visão panorâmica do defeito exibindo formação de tecido ósseo (seta) a partir da borda (b) com espessura menor na área central e interrompido por um feixe de tecido conjuntivo fibroso (seta larga); b) detalhe do tecido ósseo neoformado (seta) próxima a borda (B)

FIGURA 17 - Defeito ósseo preenchido pro Surgiplaster, 60 dias póscirurgia: visão panorâmica mostrando fechamento completo do defeito por tecido ósseo (seta) de menor espessura com uma pequena depressão na área central ocupada por uma massa de tecido ósseo trabeculado (asterisco); na região central do canal medular (M)pode-se observar a presença de uma área de tecido fibroso (TC); b e c) Detalhe da região de união do tecido ósseo neoformado (asterisco) devido ao seu crescimento pelas bordas do defeito;d) defeito em que o crescimento ósseo (asterisco) ficou restrito a borda do defeito(b) sendo a região central ocupada pelo tecido fibroso ( TC) e tecido mielóide( M) 
FIGURA 18 - Defeito ósseo preenchido por Capset, 60 dias póscirurgia. Visão panorâmica em que o crescimento ósseo (asterisco) ficou restrito a borda do defeito(b) sendo a região central invadida pelo tecido fibroso (TC) e tecido mielóide (M)

FIGURA 19 - Defeito ósseo preenchido por sulfato de cálcio da Merck, 60 dias pós-cirurgia: a) visão panorâmica do defeito exibindo pequena formação de tecido ósseo (seta) a partir da borda (B) com uma grande falha óssea (seta larga) na região central recoberta pro tecido conjuntivo fibroso; b e c) maior aumento das áreas assinaladas, mostrando as bordas ósseas(B); d) caso em que houve completo fechamento do defeito por tecido ósseo trabeculado (seta) de menor espessura que o original

FIGURA 20 - Defeito ósseo preenchido com coágulo, 180 dias póscirurgia mostrando fechamento completo por tecido ósseo de arranjo compacto, com uma pequena depressão na região central (seta larga) sem a ocorrência de comunicação entre o canal medular (M) e o periósteo

FIGURA 21 - Defeito ósseo preenchido com Surgiplaster, 180 dias, exibindo a formação de duas corticais ósseas (setas) à partir da borda do defeito de menor espessura com uma região central ocupada por tecido mielóide (M)

FIGURA 22 - Defeito ósseo preenchido com o sulfato de cálcio da Merck,180 dias, exibindo a formação de duas corticais ósseas (setas) à partir da borda do defeito de menor espessura com uma região central ocupada por tecido mielóide (M)

FIGURA 23 - a) defeito ósseo preenchido com Capset, 180 dias. Dois casos (a e b) exibindo a formação de duas corticais ósseas (setas) de menor espessura com uma região central ocupada por tecido mielóide (M)

FIGURA 24 - Cortical óssea padrão da região utilizada para a confecção do defeito 
Lista de Quadro

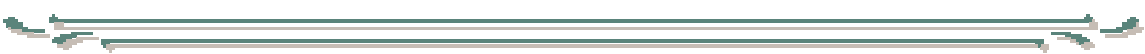




\section{LISTA DE QUADRO}

QUADRO 1 - Distribuição dos materiais nas cavidades cirúrgicas dos animais 


\title{
Lista de Abreviaturas
}

\author{
e Símbolos
}




\section{LISTA DE ABREVIATURAS E SÍMBOLOS}

AH 26 - resina epóxica - cimento para obturação do canal radicular AIDS - adquired immuno deficiency syndrome

BG - bioglass - biovidro

BOP - Polímero osteocondutor biocompatível.

${ }^{\circ} \mathrm{C}$ - grau celsius/centígrado

$\mathrm{CaSO}_{4}-$ sulfato de cálcio

cc - centímetro cúbico

cm - centímetro

DBM - matriz óssea desmineralizada

DMV - densidade de microvasos

DFDBA - desmineralized freezed dried bone allografts ( osso alógeno desmineralizado seco e congelado

e-PTFE - politetrafluoretileno expandido

g - grama

GP - gesso Paris

$\mathrm{H}_{2} \mathrm{O}$ - molécula de água

HA - hidroxiapatita

HE - hematoxilina e eosina

HA/SC - hidroxiapatita + sulfato de cálcio

$\mathrm{HTR}^{\circledR}$ - Substituto polimérico do tecido ósseo

IRM - Material restaurador intermediário

$\mathrm{kg}$ - quilograma

mg - miligrama

$\mathrm{ml}$ - mililitro

MPa - miliPascal

Mrad - miliradio

MVD - densidade de microvasos 
MTA - agregado de trióxido mineral.

$\mu \mathrm{m}$ - micrometro

$\%$ - porcentagem

PDGF - fator de crescimento derivado de plaquetas

PGLA - ácido poliglicólico

PRP - plaquet-rich plasm (plasma rico em plaquetas)

RGS - retalho gengival sozinho

$\mathrm{RP}$ - redução de profundidade

rpm - rotações por minuto

SC - sulfato de cálcio

seg - segundo

Super EBA - óxido de zinco e eugenol do tipo III com ácido etoxi-benzóico.

VB - vidro bioativo

VB/SC - vidro bioativo + sulfato de cálcio

UNESP - Universidade Estadual de São Paulo

USP - Universidade de São Paulo 
Resumo

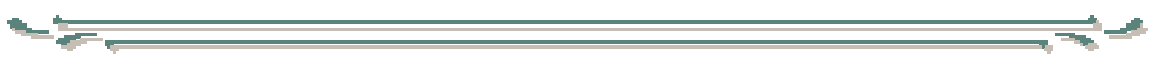




\section{RESUMO}

O objetivo deste trabalho foi avaliar, microscopicamente, o reparo ósseo em cavidades cirúrgicas de tamanho não crítico tratadas com sulfato de cálcio em 3 formulações diferentes (Capset da Lifecore-USA, Surgiplaster da Classimport-Italy e o sulfato de cálcio da Merck do Brasil). Foram confeccionados 2 defeitos ósseos de $5 \mathrm{~mm}$ de diâmetro por $8 \mathrm{~mm}$ de profundidade, usando-se trefina cirúrgica da Dentoflex, em cada epífise de fêmures de coelhos machos Nova Zelândia. 24 cavidades foram preenchidas com o sulfato de cálcio da Merck do Brasil (grupo experimental 1), 24 com Capset (grupo experimental 2), 24 com Surgiplaster (grupo experimental 3) e 8 com coágulo sangüíneo (controle). Os animais de cada grupo foram mortos 30, 60, 90 e 180 dias após a cirurgia. As epífises foram coletadas, fixadas e posteriormente descalcificadas com a solução de Morse e incluídas em parafina. Foram obtidos cortes de $6 \mu \mathrm{m}$ de espessura, os quais foram corados com hematoxilina e eosina e observados no microscópio ótico. No presente trabalho a análise microscópica dos defeitos ósseos, tratados de modo geral, mostrou ocorrência de neoformação óssea em todos os grupos estudados, indiferente da marca comercial do produto utilizado. No período de 30 dias, o grupo experimental 1 mostrou a formação de tecido conjuntivo fibroso, que ocupou parcialmente a área central do defeito. A neoformação óssea a partir da borda invaginava para o interior do canal medular acompanhando as margens desse tecido conjuntivo. O grupo experimental 2 mostrou a invasão de tecido conjuntivo no centro do defeito. Não se observou a formação do calo ósseo. O grupo experimental 3 exibiu duas 
pequenas faixas de tecido ósseo primário, das quais a externa tinha um aspecto contínuo e a interna, aspecto fragmentado; no espaço entre as duas havia tecido conjuntivo sendo substituído por tecido mielóide. Nos demais períodos de avaliação os grupos experimentais apresentaram um reparo semelhante. A análise dos cortes histológicos do grupo controle preenchido somente com o coágulo sangüíneo mostrou que o processo de reparo foi melhor aqui do que em qualquer dos grupos experimentais, em qualquer dos períodos de avaliação. 
1

Introdução 


\section{INTRODUÇÃO}

A busca pelo reparo de defeitos ósseos vem, de longa data, despertando o interesse de pesquisadores, sempre empenhados no desenvolvimento de materiais que apresentem características biológicas aceitáveis e possam ser usados como substitutos dos tecidos ósseos. Os estudos nessa linha sinalizam que o enxerto autógeno é o material mais indicado para preenchimento de defeitos ósseos, por causa do potencial osteogênico. No entanto, nem sempre a utilização desse material é viável, pois situações como tamanho do defeito, desconforto do paciente, tempo de recuperação e quantidade insuficiente de tecido doador muitas vezes limitam sua utilização (GRANJEIRO et al ${ }^{39} .1992$; MARX ${ }^{63}, 1994$; JENSEN et $\mathrm{al}^{46}$. 1996).

Segundo LINDLHEN ${ }^{59}$, em 2000, os materiais de enxerto podem ser divididos em:

a) Autógeno: quando o tecido pertence ao mesmo indivíduo. Nesse caso remove-se o osso de uma área doadora do próprio paciente (crista ilíaca, mento, etc.) para implantes na área receptora. Esse procedimento implica a realização de duas cirurgias, uma na área doadora e outra na receptora, muitas vezes em ambiente hospitalar e, além disso, nem sempre há quantidade suficiente de tecido para preencher o defeito.

b) Homógeno: o doador é da mesma espécie do receptor, porém de constituição genética diferente. Nesse caso o enxerto é obtido de um banco de ossos. Além das dificuldades para conseguir tecidos bem preservados e 
dos custos da manutenção de um banco de tecidos, tem-se ainda o risco da transmissão de infecções graves como a AIDS e a hepatite.

c) Heterógeno ou xenógeno: o doador é de uma espécie diferente do receptor. É o caso do osso liofilizado de origem bovina, que passa por um processo de preparo para a eliminação de determinantes antigênicos, mas com a manutenção da capacidade osteogênica.

d) Aloplástico: material sintético ou natural, inerte aos tecidos orgânicos, podendo ser de natureza metálica, cerâmica ou plástica. Os materiais sintéticos são denominados materiais de implante. Destaca-se aqui a hidroxiapatita, polímeros, colágeno, sulfato de cálcio, biovidro, etc, que podem ser oferecidos em forma de blocos, partículas ou pó e membranas, cada um com sua particularidade.

Segundo MACNEILL et al. ${ }^{60}$, em 1999 e MELLONIG ${ }^{67}$, em 2000, um material ideal para ser utilizado como substituto ósseo deve ser biocompatível, não-antigênico, não- carcinogênico, apresentar baixo custo e poder ser gradualmente substituído por tecido ósseo, possuindo propriedades osteoindutoras e osteocondutoras.

Os materiais aloplásticos podem ser não-reabsorvíveis e absorvíveis. Os não- reabsorvíveis perpetuam-se na área e conseqüentemente competem com a neoformação óssea. Os reabsorvíveis, por sua vez, são eliminados da área em tempo variável, de acordo com o material, propiciando a formação de um novo osso e o fechamento do defeito cirúrgico.

Esses biomateriais podem atuar na formação óssea por vários mecanismos: osteoindução, osteocondução, osteogênese e osteopromoção.Os biomateriais osteoindutores são aqueles com capacidade de induzir a diferenciação de células mesenquimais indiferenciadas em condroblastos e osteoblastos, com formação de novo osso por ossificação endocondral. Os osteocondutores, por seu turno, favorecem a proliferação e 
a migração de células ósseas sobre a sua superfície. Os osteogênicos são materiais orgânicos capazes de estimular os osteoblastos pré-existentes na deposição de maior quantidade de matriz. Por fim, a osteopromoção é o processo que utiliza um meio físico ou uma barreira física de biomaterial em forma de membrana para recobrir o defeito ósseo, o que impede a invaginação do tecido conjuntivo frouxo e propicia um direcionamento da formação óssea e uma osteogênese normal (DAHLIN $\left.{ }^{25}, 1996\right)$.

Uma grande variedade de materiais biológicos e sintéticos está sendo avaliada para tratamento cirúrgico de perda óssea alveolar (STEPHAN et al. $^{107}$, 1999). Para BOYNE ${ }^{15}$, em 1958, biomateriais obtidos de outras espécies de animais são recomendados para a reposição desse tipo de perdas ósseas. Uma gama de materiais substitutos de osso ou biomateriais tem sido proposta para utilização como enxerto, sendo também pesquisados métodos que minimizem a reação inflamatória e contribuam para a melhora da regeneração óssea.

Para WILLIAMS ${ }^{117}$, em 1999, o biomaterial é uma substância ou combinação de substâncias, de origem orgânica ou sintética, capaz de melhorar, aumentar ou substituir total ou parcialmente tecidos ou órgãos que sofreram alterações. Assim, o biomaterial se caracteriza pela biocompatibilidade, comportando-se de maneira inerte do ponto de vista biológico, sem causar nenhum efeito secundário nocivo ao organismo.

O uso dos biomateriais na clínica odontológica vem assumindo uma importância cada vez maior em decorrência das várias possibilidades de aplicação e das facilidades que os mesmos oferecem. Assim, os biomateriais têm sido utilizados com o objetivo de restabelecer a função e a morfologia de áreas que sofreram intervenções cirúrgicas, que apresentam aumento de rebordo alveolar atrófico, defeitos ósseos ocasionados por lesões periapicais, periodontais ou perdas ósseas por traumatismo, além dos casos de implantes e do uso como veículos carreadores de fatores de 
crescimento. Dentre os biomateriais, destaca-se o sulfato de cálcio (SC), um material biocompatível, com propriedades osteocondutoras, ou seja, esse biomaterial mantém um arcabouço sobre o qual ocorre a neoformação óssea.

Nos dias atuais já estão ao alcance do profissional diversas formulações comerciais de sulfato de cálcio, como Capset, Surgiplaster e o próprio sulfato de cálcio di-hidratado.

Pelas possibilidades de uso, principalmente nas áreas de Periodontia, Implantodontia, Cirurgia Buco-Maxilo-Facial e especificamente na Cirurgia Parendodôntica, em substituição aos enxertos autógenos ou heterógenos, justifica-se aqui a avaliação histológica do comportamento biológico de 3 marcas comerciais de SC, de diferentes procedências: a) Capset (LifecoreUSA), b) Surgiplaster (Classimport-Italy) e c) sulfato de cálcio di-hidratado (Merck do Brasil). 
2

Revisão da Literatura 


\section{REVISÃO DA LITERATURA}

O primeiro relato sobre o emprego do sulfato de cálcio (gesso Paris) para preenchimento de defeitos ósseos, em pacientes portadores de lesões ósseas, foi feito por DREESMAN ${ }^{30}$, em 1892, em Bonn. Os resultados mostraram que, de 8 pacientes, 6 apresentaram preenchimento com osso, um paciente teve uma cicatrização incompleta e no último não houve regeneração do defeito ósseo.

STACHOW ${ }^{105}$, em 1894, fez experiências com ovelhas e verificou que os defeitos operatórios em ossos longos, quando preenchidos com o gesso Paris e o periósteo colocado sobre ele, apresentaram uma reabsorção do gesso e conseqüentemente uma regeneração do osso. O gesso Paris mostrou ser bem tolerado pelo tecido, que apresentou apenas uma leve inflamação.

Embora o SC tenha sido usado durante anos seguidos para preencher defeitos ósseos numa extensão limitada, não apareceram outros relatos até 1925 , quando KOFMANN ${ }^{54}$, em 1925, apresentou o resultado final do caso de um paciente com um abscesso na tíbia, operado em 1912. O SC, segundo o relato, fora usado para preencher as cavidades ósseas, com bons resultados.

PETROVA $^{90}$, em 1928, fez experimentos com cães no Instituto de Traumatologia em Leningrado, nos quais anti-sépticos, Kreolin a 10\% ou 
Rivanol a 10\%, foram adicionados ao SC antes de este ser inserido nos defeitos ósseos infectados ou não- infectados. Em 10 cães com feridas nãoinfectadas houve completa restituição da arquitetura óssea normal, incluindo a cavidade medular, no final de 6 a 8 meses. O tempo médio requerido para o mesmo resultado em 18 cães com feridas infectadas foi de 10 meses. Todos os defeitos em ambos os grupos cicatrizaram.

Em 1930, EDBERG ${ }^{31}$, inseriu gesso Paris em cavidades ósseas infectadas em 6 pacientes. Em 2 destes com cisto dentígeno e 1 com um abscesso do ílio, o SC foi extruído e a cicatrização falhou. Nos casos de dois pacientes com cavidades tuberculosas em osso e 1 paciente com uma cavidade osteomielítica, as cavidades cicatrizaram solidamente.

NIELSON ${ }^{75}$, em 1944, produziu um relato mais extenso, com informações relativas aos resultados finais obtidos após a inserção de SC em 14 pacientes com cavidades ósseas limpas, e em 16 com cavidades ósseas infectadas, 2 destas tuberculosas. Nove destes pacientes foram acompanhados por 4 a 7 anos e meio. Não houve complicações atribuídas à implantação do SC. Os resultados foram satisfatórios tanto nas cavidades limpas quanto nas infectadas.

KOVACEVIC ${ }^{55}$, em 1953, no seu artigo referente ao uso do SC para preencher defeitos ósseos, relatou o caso de 3 pacientes com osteomielite hematogênica de tíbia, nos quais foi realizada diafisectomia. Os defeitos foram preenchidos com cilindros de SC associado a pó de penicilina e sulfonamida. Ocorreu a cicatrização com reconstituição da diáfise nos três casos.

Em 1956, PELTIER ; LILLO $^{88}$, relataram experimentos usando cilindros de SC, esterilizados a $200^{\circ} \mathrm{C}$ por 48 horas, implantados em defeitos cirúrgicos subperiostais preparados em cães. Eles concluíram que as ressecções eram grandes demais para ocorrer a regeneração 
espontânea, não encontrando uma relação direta entre a ocorrência do reparo ósseo e o comprimento dos defeitos ósseos preenchidos com gesso. Também não encontraram diferença aparente entre os cilindros de SC (gesso) do tipo comercial e os do tipo dentário. Em 14 cães com defeitos subperiostais (radio), observaram radiograficamente, o completo desaparecimento do material entre 45 e 72 dias e a completa regeneração dos defeitos em aproximadamente 3 meses. A reabsorção do SC foi acompanhado por aumento do cálcio sérico nos cães. Assim que a formação óssea progrediu, histológica e radiograficamente, os níveis de cálcio retornaram à normalidade. Em um segundo estudo, os defeitos foram analisados com a remoção do tecido periostal adjacente. Houve regeneração parcial em dois dos nove animais estudados. Nenhuma regeneração pôde ser observada, histológica ou radiograficamente, nos sete animais remanescentes. Em todos os animais, observaram reabsorção completa do SC. O SC sozinho não foi osteogênico, mas, associado ao periósteo, foi capaz de acelerar a formação óssea.

Em, 1956, NIKULIN ; LJUBOVIC ${ }^{76}$, publicaram um extenso relato das suas observações sobre o implante de SC em ossos de coelhos. Concluíram que o implante desse material em áreas subperiostais de osso resseccionado não produz inflamação maior do que aquela normalmente encontrada em fraturas não-infectadas. A regeneração do osso em área de ressecção subperiostal ocorre mais cedo do que quando é usado um enxerto autógeno. O SC não estimula a osteogênese na ausência de osso ou periósteo. O novo osso originado na área na qual o gesso foi implantado é normal. Nenhum efeito prejudicial atribuído à implantação desse material foi notado nos tecidos adjacentes ou em órgãos distantes. Uma suave elevação do cálcio sérico e da fosfatase alcalina acompanhou a reabsorção do gesso implantado em ossos de coelhos.

Em 1957, PELTIER et al. $^{89}$, fizeram experimentos adicionais colocando SC em defeitos metafisiais em seis cães. Ocorreu regeneração 
completa em cinco cães; o sexto cão mostrou crescimento ósseo, porém a substituição foi incompleta. Histologicamente, foram observadas partículas pequenas de SC na matriz óssea, porém nenhuma reação de corpo estranho pôde ser demonstrada. A regeneração óssea foi normal em todos os aspectos e houve reabsorção osteoclástica de osso ao longo das paredes dos defeitos nos estágios iniciais da cicatrização.

$B E L L^{12}$, em 1960, sugeriu que o sucesso de um enxerto ósseo é dependente parcialmente da reabsorção rápida do enxerto pelo hospedeiro. Indicou que implantes ósseos autógenos eram reabsorvidos mais rapidamente do que o osso inorgânico obtido de osso seco congelado. Comparou a razão da velocidade de reabsorção de implantes de osso autógeno, osso seco congelado, osso homólogo, osso inorgânico, osso bovino e SC. Colocou os implantes com $3 \mathrm{~mm}$ de diâmetro e $2 \mathrm{~mm}$ de espessura entre os músculos gastronêmios de 17 cães adultos. Determinou as taxas de reabsorção dos implantes por radiografias obtidas em intervalos semanais. Implantes de SC foram mais rapidamente reabsorvidos, numa média de 4,7 semanas. A reabsorção de implantes autógenos requer uma média de 7,0 semanas, de homólogos, 10 semanas e de osso bovino, 11,5 semanas. O osso inorgânico seco congelado reabsorveu lentamente, freqüentemente mostrando mínima ou nenhuma alteração radiográfica após 16 meses.

LEBOURG ; BIOU ${ }^{56}$, em 1961, usaram gesso Paris para preencher feridas remanescentes após exodontia de terceiros molares impactados e outros defeitos ósseos de mandíbula e maxila. Três ou quatro semanas após o implante, evidências radiográficas mostraram que o gesso havia sido completamente reabsorvido e a cicatrização era maior quando comparada aos controles.

Em 1961, PELTIER ${ }^{87}$, publicou um extenso trabalho, onde descrevia um exaustivo histórico sobre o uso do SC, uma pesquisa experimental em 
defeitos ósseos em radio de cães e um relato de 20 casos clínicos de pacientes com as mais variadas patologias ósseas. A análise histológica mostrou que a presença do SC não causava uma reação inflamatória severa; não foi observada a reação do tipo corpo estranho de células gigantes; houve um crescimento de um novo osso dentro do defeito quando do implante do SC; a sua presença não inibiu e nem estimulou a osteogênese. Quanto aos casos clínicos, o SC pareceu ser um ótimo material de preenchimento de defeito ósseo; é seguro, a absorção do SC e subseqüente regeneração do osso ocorreu rapidamente (meses); não inibiu o crescimento e a reparação do tecido ósseo; Quando o SC era empregado em cavidades infectadas não ocorreram riscos ou complicações.

RADENTZ ; COLLINGS $^{92}$, em 1965, fizeram implantes de SC em alvéolos de cães. Criaram 30 bolsas infra-ósseas em 10 cães. Em cada animal, duas bolsas foram preenchidas com SC e uma ficou vazia servindo como controle. Os cães foram sacrificados em um período de 3 a 12 semanas após o implante. Radiografias foram feitas após o implante e antes do sacrifício. Os resultados mostraram cicatrização similar no grupo controle e no do SC, havendo uma cicatrização de padrão melhor nos casos do implante de SC. Histologicamente, em ambos os grupos, houve uma pequena proliferação epitelial na área da bolsa quando esta se apresentou livre de inflamação. A regeneração óssea do defeito controle foi muito similar à do defeito preenchido com SC, exceto que este aparentou ter uma cicatrização mais rápida e fácil. A melhora do padrão de cicatrização deve, provavelmente, ser atribuída ao efeito selador do SC, que age impedindo a entrada de material estranho e o crescimento de epitélio superficial na ferida. A taxa de cicatrização de um defeito ósseo nos cães parece ser inversamente proporcional à severidade e duração da inflamação. Todos os implantes reagiram adversamente ao aumento da inflamação, ao passo que a cicatrização prosseguiu numa razão rápida, quando a inflamação foi mantida no mínimo. 
Em 1966, BAHN ${ }^{9}$, criou defeitos bilaterais cirurgicamente em 10 mandíbulas de coelhos. Preencheu os defeitos do lado direito com SC mais fluido e os do lado esquerdo, que serviriam de controle, com sangue. Os animais foram sacrificados em intervalos designados examinando-se as mandíbulas microscópica e clinicamente. Os defeitos dos animais sacrificados com 4 dias revelaram hemorragia bilateral, fragmentos ósseos necróticos, inflamação moderada, fibrina, proliferação fibroblástica e vascular. Bahn observou maior reparo ósseo no defeito controle, concluindo que, nos estágios iniciais de reparo ósseo, a cicatrização foi inibida pela pressão do gesso solidificado contra as margens dos defeitos. Após o período inicial de 4 a 6 dias, o fluido tecidual na área iniciou uma reabsorção marginal de volume de SC. A regeneração óssea foi acelerada em todos os defeitos experimentais subseqüentes, sendo evidenciada a predominância de tecido osteóide e novo osso nas áreas de implantação do SC comparadas com as do grupo controle. Nos coelhos sacrificados aos 22 dias após a cirurgia, o defeito estava preenchido com osso, enquanto fibroblastos e atividade osteóide estavam ainda evidentes no lado controle. No $54 .^{2}$ dia, o trabeculado estava mais grosso e mais extenso nos defeitos experimentais. BAHN ${ }^{9}$ concluiu que houve um aumento da regeneração óssea com a implantação de SC fluido nos defeitos preparados cirurgicamente nas mandíbulas de coelhos, sem reações de células gigantes de corpo estranho.

VICTOR et al. ${ }^{112}$, em 1975, estudaram o comportamento do SC em implantes intra-ósseos em ratos, para avaliar a possibilidade de seu emprego em cirurgias bucais. Foram utilizados 36 ratos, machos, divididos em 2 grupos de 18 animais, sendo um grupo controle e outro com o SC. Foram extraídos os incisivos superiores direitos de todos os ratos. No grupo controle, das feridas preenchidas com sangue, a mucosa foi suturada com fio de poliéster 4-0. No 2. ${ }^{\circ}$ grupo, os alvéolos receberam o SC previamente preparado e as bordas da ferida foram suturadas com o mesmo fio do controle. Os animais foram sacrificados 1, 6, 12, 18, 24, 30 e 40 dias após o ato operatório. As peças obtidas foram fixadas em formalina a $10 \%$, 
descalcificadas em solução de citrato de sódio e ácido fórmico e incluídas em parafina; os cortes foram corados pela hematoxilina e eosina. O material implantado no alvéolo foi em parte absorvido pelo organismo e em parte expulso através do alvéolo dental. A presença de qualquer substância no interior do alvéolo dental, mesmo que bem tolerada pelo organismo, retarda a cronologia do processo de reparo por perturbar a organização do coágulo. Victor et al. concluíram que o SC não deve ser utilizado em cirurgias ósseas bucais, pela intensa reação inflamatória e reabsorções ósseas que provoca, retardando consideravelmente o processo de reparo nos alvéolos dentais.

Em 1975, FRAME ${ }^{33}$ investigou o sulfato de cálcio di-hidratado como uma alternativa possível ao enxerto ósseo autógeno usado para auxiliar na restauração de defeitos ósseos no maxilar. Foi induzida uma porosidade conveniente no material utilizando-se uma técnica estandartizada para dar porosidade reproduzível à matriz di-hidratada. Frame investigou a estrutura e a interconexão dos poros, determinando o volume real, a distribuição e tamanho dos poros, bem como a resistência a cisalhamento e a tensão. Concluiu que os métodos de esterilização por calor não são adequados devido à conversão do sulfato de cálcio di-hidratado a uma forma hemihidratada, sendo indicada a esterilização por radiação gama de cobalto 60 na dose de 2,5 Mrad. Com estes métodos, foram produzidos blocos de sulfato de cálcio di-hidratado estéril, de pureza e porosidade conhecidas e adequados a implantes em animais. O estudo em animal teve como objetivo determinar a razão de degradação do material in vivo e secundariamente examinar a reação dos tecidos circunvizinhos. Doze blocos esféricos medindo $6 \mathrm{~mm}$ de diâmetro e $75 \pm 2,5 \%$ de porosidade foram implantados em subcutâneo na região da coluna vertebral de doze ratos SpragueDawley. Fez-se também incisão similar em cada animal como controle, sem a colocação de implante. Frame acompanhou semanalmente os defeitos ósseos por meio de radiografias, sacrificando 3 animais na $1 .^{a}, 2 .^{a}, 4 .^{a}$ e $8 .^{a}$ semanas. Os implantes porosos se degradaram completamente em uma semana, o que foi demonstrado radiograficamente. Houve uma reação 
localizada de acordo com a degradação do material no tecido e a proliferação de tecido de granulação, que maturou em uma cicatriz densa com pequena reação tecidual circunvizinha. Uma técnica foi desenvolvida para reduzir a taxa de reabsorção pela cobertura do gesso, usando-se um material conhecido por ser bem tolerado pelos tecidos e ter uma taxa conhecida de degradação. Antes do implante, os blocos foram imersos por alguns segundos em n-butil-2 cianoacrilato contendo um inibidor sulfone. Frame radiografou os ratos e os sacrificou após a $1 .^{a}, 2 .^{a}, 4 .^{a}$ e $8 .^{a}$ semanas. Radiograficamente não houve evidência de degradação de implantes após 6 meses. Histologicamente houve menor reação tecidual nos blocos descobertos. Frame concluiu que o sulfato de cálcio impregnado com n-butil2-cianoacrilato foi bem tolerado pelos tecidos e provocou pequena reação inflamatória, formando uma matriz densa que foi lentamente dissolvida.

Já em 1980, FRAME $^{35}$ avaliou o sulfato de cálcio poroso di-hidratado com uma cobertura superficial de n-butil-2-cianoacrilato implantado em defeitos circulares na calota craniana de coelhos. O objetivo era determinar a extensão das substituições desse material por osso e examinar a reação de tecido circunvizinho. Frame utilizou uma trefina de $15 \mathrm{~mm}$ de diâmetro para remover um disco circular de osso da linha mediana da abóbada craniana de cada coelho, sendo utilizado um total de 16 animais. O sulfato de cálcio di-hidratado poroso foi saturado com o próprio sangue do animal e uma fina camada de n-butil-2-cianoacrilato foi aplicada nas superfícies inferiores e superiores; a circunferência foi deixada sem proteção. Cada animal recebeu um bloco na linha mediana da abóbada craniana e todos foram recobertos. No grupo controle, Frame preencheu as cavidades com coágulo sangüíneo. Foram sacrificados oito coelhos após 24 semanas e o restante, após 36 semanas. Radiografias foram realizadas nas áreas de implante. Nos espécimes do grupo controle de 24 semanas, Frame visualizou um novo osso formado na periferia, em forma de ilhotas isoladas. Histologicamente, houve um crescimento do osso das margens, que não ficou tão espesso como no crânio adjacente, apresentando algumas 
espículas na periferia, sem a calcificação completa. Implantes com 24 semanas não mostraram radiograficamente calcificação completa e uma área central radiolúcida. Histologicamente mostraram crescimento ósseo das margens, a ponte incompleta e um tecido fibroso que preenchia a fenda remanescente. No grupo controle de 36 semanas, os aspectos radiográficos foram semelhantes aos observados no grupo controle de 24 semanas deposição de osso na periferia do defeito - mas a parte central não apresentava calcificação. Histologicamente os defeitos mostraram um novo osso formado principalmente nas margens e separado por ossículos, contendo no seu interior o tecido medular. No grupo experimental de 36 semanas, as radiografias mostraram deposição de um novo osso com padrão concêntrico. Nenhum caso mostrou uma completa deposição de osso fechando o defeito. Histologicamente os defeitos mostraram um novo osso, contendo tecido hematopoiético, na periferia com denso tecido conjuntivo ocupando o centro do defeito.

BEESON $^{11}$, em 1981, analisou histológica e radiograficamente o uso de SC quando implantado no seio frontal de cães. Usou o SC misturado com água estéril para obliterar os seios frontais em 6 cães e fez as mesmas operações em 3 cães sem obliterar os seios, para controle. Obteve os níveis de cálcio sérico pré-operatoriamente e semanalmente em cada cão. Obteve radiografias do seio e varredura óssea mensalmente em cada espécime. Sacrificou dois cães com implantes e um controle em intervalos de 10, 20 e 24 semanas. Após a remoção dos ossos frontais e das peças descalcificadas, e do processamento histológico, a avaliação foi realizada por meio da microscopia eletrônica de varredura. Todos os cães toleraram bem a cirurgia, não houve casos de infecção pós-operatória ou rejeição do implante. Níveis de cálcio sérico foram elevados pós-operatoriamente nos cães com implantes de SC, porém a elevação não foi substancial e nenhum efeito sistêmico foi notado nos cães. O exame radiográfico mostrou a opacificação contínua dos seios frontais dos cães implantados e nenhuma evidência de opacificação ou formação óssea nos cães controle. Concluiu-se 
que o SC parece estimular a osteogênese quando implantado em contato com osso ou periósteo. A regeneração óssea parece ser normal. Nenhum efeito deletério atribuído à implantação foi encontrado nos tecidos adjacentes ou órgãos distantes. O SC poderia, assim, ser aplicado para reconstrução óssea na cabeça e pescoço.

Em 1984, HANKER et al. $^{42}$, pesquisaram o SC como suporte para incorporação de hidroxiapatita $(\mathrm{HA})$. Foram feitas osteotomias de borda inferior posterior do corpo da mandíbula em 4 coelhos e 2 macacos, sendo o enxerto aloplástico de HA/SC colocado em um lado e, no outro, HA em solução salina somente. Cautelosamente, os implantes foram cobertos com periósteo. No caso dos macacos, medula aspirada do ilíaco autógeno foi agregada ao implante HA/SC. Em seguida foi feita a sutura. Radiografias mostraram que o sulfato de cálcio conteve as partículas de HA melhor do que a solução salina e que a reabsorção de SC ocorreu em poucas semanas. Ossificação ocorreu na interface com partículas HA. Estes achados sugerem que o composto HA/SC pode ser útil na reconstrução cirúrgica de perda óssea resultante de reabsorção, trauma ou tumor.

MCKEE ; BAILEY ${ }^{66}$, em 1984, avaliaram o sulfato de cálcio implantado em defeitos criados no corpo e ramo das mandíbulas de cães, averiguando a importância do recobrimento com o periósteo após a inserção do SC. Foram utilizados nesse experimento cinco cães, dos quais 2 tiveram um defeito de $3 \times 2 \mathrm{~cm}$ criado no corpo da mandíbula em ambos os lados por meio de um acesso extra-oral. Foi removido o periósteo da cortical somente do lado direito de cada animal. Outros 2 animais tiveram defeitos de tamanho igual criados por acesso extra-oral na área do ramo da mandíbula, em ambos os lados desta. Somente do lado direito o periósteo foi completamente removido. Todos os defeitos, nos quatro animais, foram preenchidos com SC. Um quinto animal, controle, teve um segmento de $3 \times 2$ $\mathrm{cm}$ do osso removido do corpo direito da mandíbula e do ramo ascendente esquerdo, sem preenchimento com SC. O periósteo foi removido do local 
cirúrgico no lado direito. O periósteo, quando presente, foi suturado sobre o $\mathrm{SC}$ e os tecidos moles e pele foram fechados sobre o defeito. Os animais foram sacrificados 6 meses após a cirurgia e os defeitos foram examinados tanto radiográfica como histologicamente. A infecção limitou um pouco o sucesso desse estudo, mas em alguns animais sem uma maior infecção o sucesso foi alcançado na colocação de SC, ocorrendo uma nova formação do osso com ou sem a presença do periósteo.

Em 1986, HÖGSET ; BREDBERG ${ }^{43}$, estudaram o aumento da temperatura quando o SC se solidifica, com relação ao tipo de solução adicionada, ao volume e ao ambiente. Foi também investigada histologicamente a biocompatibilidade do SC, quando implantado em tecido mole. Esterilizou-se gesso tipo odontológico em estufa a $160^{\circ} \mathrm{C}$ por 2 horas. Dez partes de SC foram misturadas com 3 partes de água destilada a temperatura ambiente ou com solução de cloreto de sódio. Estudaram uma mistura fresca de 10 a 20 cc sob 3 condições diferentes: 1) em um recipiente aberto; 2) em um recipiente isolado; 3 ) em um ambiente fisiológico em abdômen de cobaia. A temperatura de endurecimento do gesso foi registrada por 1 hora com uma sonda de par termoelétrico de 0,5 $\mathrm{mm}$ de diâmetro conectada a um medidor. Para estudar a biotolerância do material, eles implantaram tabletes de SC de $2 \mathrm{~mm}$ de diâmetro no músculo paraespinhal de 20 cobaias fêmeas. Foi feito controle dos enxertos de osso e/ou da cartilagem do quadril. Foram estudados quatro grupos de 5 animais e, após 1, 2, 4 e 6 meses da experiência, foi avaliada a resposta tecidual com microscopia óptica, levando-se em consideração a inflamação local, a reação de corpo-estranho e o tipo de integração tecidual adjacente ao implante. Os autores obtiveram como resultados das propriedades térmicas: a temperatura foi mais alta nas misturas de $20 \mathrm{cc}$ do que nas de $10 \mathrm{cc}$ para água e solução de cloreto de sódio nas 3 condições. Na mistura do SC com cloreto de sódio, a temperatura máxima foi mais alta e mais rápida sob as 3 condições, na comparação com a mistura com água. A diferença de temperatura média máxima entre ambas as misturas foi estatisticamente 
significante nos recipientes abertos e isolados; no abdômen houve uma diferença similar. A diferença do tempo de elevação (média de tempo para alcançar a temperatura máxima) das duas misturas foi significante no abdômen; uma análoga, mas não conclusiva diferença foi encontrada no recipiente aberto e no isolado. A temperatura máxima medida no recipiente isolado foi maior do que as observadas no abdômen. A temperatura da mistura SClágua no abdômen de cobaia ficou abaixo dos limites fisiológicos. Quanto à biocompatibilidade, os implantes de SC foram bem tolerados. Não foram encontradas infecções ou rejeições após 1, 2 ,4 e 6 meses. Aos 6 meses, apenas um dos 5 espécimes tinha remanescentes de SC.

FRAME ; BROWNE ${ }^{36}$, em 1987, estudaram o aumento de rebordo de áreas edêntulas de cães usando partículas sólidas e porosas de hidroxiapatita (HA) pura ou combinada com osso autógeno triturado e fino ou com SC. Foi comparada a cicatrização das formas sólidas e porosas de HA e especialmente as quantidades relativas de osso neoformado, o efeito da mistura de osso autógeno com partículas de HA, com especial referência a sua capacidade de induzir a osteogênese, a reação tecidual do SC combinado com os dois tipos de HA e qualquer alteração no comportamento biológico. Os autores removeram os $3 .^{\text {os }}$ e $4{ }^{\text {os }}$ pré-molares superiores e inferiores e $1 .^{\text {os }}$ molares bilateralmente de 6 cães; o osso alveolar foi removido com uma broca para estimular rebordos atróficos. Foram criados 4 locais de implante em cada um dos 6 animais e cada rebordo foi aleatoriamente distribuído para receber $3,0 \mathrm{ml}$ de partículas de HA sólida e densa; 3,0 ml de partículas de HA porosa; $1,5 \mathrm{ml}$ de partículas sólidas de HA densa e combinada com igual volume de osso trabecular autógeno; 1,5 ml de HA porosa combinada com igual volume de osso autógeno; $2,5 \mathrm{ml}$ de partículas de HA sólida combinadas com SC, usando-se uma razão de $4 \mathrm{ml}$ de HA para $1 \mathrm{~g}$ de SC; e 2,5 ml de partículas de HA porosa combinadas com SC, usando-se a mesma proporção. Foram realizadas radiografias e fotografias antes e imediatamente depois do implante e com 1, 4, 12 e 24 semanas do período pós-operatório. Após o sacrifício dos animais, secções 
foram preparadas, sendo metade dos espécimes utilizada para determinar a força relativa das áreas ampliadas e a outra metade dividida em duas porções para descalcificação. As secções descalcificadas foram coradas por hematoxilina e eosina e as não-descalcificadas por azul de toluidina. Os resultados mostraram que os rebordos foram ampliados e estáveis, cobertos com mucosa saudável. Radiograficamente houve um achatamento de todos os rebordos durante as primeiras 4 semanas, depois os contornos não mais se alteraram. As partículas sólidas densas remanesceram com discreta radiopacidade, enquanto as partículas HA porosas foram menos radiopacas, com uma densidade similar à do osso subjacente, e se tornaram menos definidas em 24 semanas. A mistura HA/SC mostrou uma redução marcante na opacidade entre a $1 .^{a}$ e a $4 .^{a}$ semana e uma aparência estável. A quantidade de osso novo nos rebordos ampliados com SC e HA foi similar à dos outros grupos e o SC não interferiu na cicatrização. Houve evidência de reabsorção da cortical óssea subjacente em vários espécimes.

Em 1988, ELKINS ; JONES ${ }^{32}$, compararam os efeitos de implantes de $\mathrm{SC}$ e de osso esponjoso autógeno, puros ou misturados em proporções iguais, na cicatrização de defeitos corticais criados cirurgicamente em fêmures de cães. Foram utilizados 12 cães adultos, com 4 defeitos de 0,25 polegada de diâmetro na cortical diafisial lateral do fêmur direito de cada animal. Um defeito foi deixado sem preenchimento como controle e os demais foram preenchidos com osso esponjoso, SC ou a mistura de ambos. Avaliaram a intensidade da cicatrização óssea radiográfica e histologicamente em 2, 4, 6, 8, 10 e 12 semanas. Radiograficamente, não se chegou a nenhuma conclusão objetiva, em decorrência do pequeno tamanho dos defeitos e da quantidade limitada de SC implantado. Clinicamente não houve problemas com infecção ou aleijamento de qualquer cão após a cirurgia. Foram medidos os níveis de cálcio sérico e fósforo semanalmente. Nenhuma reação de tecido mole foi observada e todas as incisões cicatrizaram. Não houve evidência de inflamação ou reação de corpo estranho na área das cavidades. Não foram constatadas diferenças na 
intensidade da cicatrização óssea com o osso esponjoso autógeno, o SC e a mistura de ambos. Todos os implantes foram superiores ao defeito controle.

PARSONS et al. $^{79}$, em 1988, desenvolveram um composto de hidroxiapatita (HA) em partículas associadas ao SC hemi-hidratado. O SC inicialmente atua como um suporte para manter as partículas de HA no lugar; após a reabsorção subseqüente, propicia à matriz uma porosidade que favorece o crescimento ósseo. A combinação de SC e HA resultou num composto com propriedades superiores às dos materiais quando empregados sozinhos. O diâmetro médio das partículas é aproximadamente de $300 \mu \mathrm{m}$, o que favorece a sua condensação e promove a condução eficiente do osso entre as partículas com a reabsorção posterior do SC. O composto foi submetido ao teste mecânico e da degradação in vitro. Os testes apontaram uma porcentagem de $35 \%$ de SC como resistência à compressão adequada (10 $\mathrm{MPa})$ e a degradação in vitro em solução fisiológica foi de 5 dias a $37^{\circ} \mathrm{C}$, tendo então o SC se dissolvido, com a força de compressão diminuindo para 4,5 $\mathrm{MPa}$. Os compostos foram também implantados em 2 defeitos ósseos de 2,7 mm de diâmetro em tíbias de coelho (New Zealand), sendo um terceiro defeito deixado sem preenchimento como controle. Após 2 e 4 semanas os coelhos foram sacrificados e as áreas processadas histologicamente. No grupo controle, após 4 semanas, ocorreu um crescimento ósseo incompleto caracterizado por uma camada fina de novo osso estendendo-se através da cavidade. Este osso provavelmente originou-se do endósteo, periósteo ou ambos. Com o HA ocorreu crescimento ósseo rápido, de consistência trabecular nos poros entre suas partículas. Em duas semanas, muito do SC foi reabsorvido e o trabeculado ósseo foi sendo formado nos poros entre as partículas. Em 4 semanas o crescimento trabecular estava completamente infiltrado no local do implante e não havia remanescente de SC. Quando vista sob microscopia eletrônica de varredura, a interface entre o osso e a HA mostrou direta adesão do osso com nenhuma intervenção do tecido conjuntivo. O SC no composto mostrou ser biocompatível, formando uma matriz com a HA, e foi 
reabsorvido após o crescimento tecidual inicial, o que permitiu uma fixação inicial do implante sem interferência no crescimento ósseo e aparentemente preveniu a migração de partículas. Prosseguindo os estudos sobre este composto $(\mathrm{SC}+\mathrm{HA})$, os autores o implantaram em alvéolos de 6 cães beagle machos de 11 meses de idade. Os incisivos superiores e inferiores e os pré-molares foram removidos. Os alvéolos do lado esquerdo permaneceram vazios e serviram como controle. Na mandíbula, os alvéolos do lado direito foram usados como controle e os da esquerda preenchidos com o composto de SC-HA. O composto foi inserido em forma de gel com um porta-amálgama. O exame revelou uma epitelização sobre o implante de 1 semana, similar à observada no controle. O SC estava presente e aparentemente nenhuma partícula foi perdida, apesar da abertura. Em 78 implantes, não houve casos de extrusão através dos alvéolos. Com o tempo, o SC foi reabsorvido e o crescimento ósseo progrediu. O osso alveolar foi preservado na região dos alvéolos preenchidos. Nos alvéolos de controle ocorreu um processo de reabsorção. Os autores concluíram que a associação de SC e HA pode ser uma alternativa útil ou um coadjuvante para o enxerto ósseo autógeno.

Utilizando o coelho como modelo experimental, NAJJAR et al. ${ }^{72}$, em 1991, compararam a quantidade de neoformação óssea com diferentes tipos de biomateriais, quando colocados em defeitos bilaterais criados na mandíbula e na tíbia. Os materiais utilizados foram a $H A 500 \circledast$, polímero $H T R \circledast$ e uma mistura de $H A 500 ®$ e sulfato de cálcio hemi-hidratado (gesso Paris). Os resultados não mostraram diferenças clínicas entre os grupos experimentais e não havia sinais de inflamação ao redor dos implantes. A porcentagem de osso aumentou durante os períodos de avaliação, porém não houve diferenças estatísticas. As porcentagens médias de neoformação óssea para o HTR $®$ em duas e seis semanas foram de 44,37\% e 45,27\%; para HA $500 \AA$ foram de $50,14 \%$ e $50,00 \%$ e para a mistura HA $500 \AA+$ SC hemi-hidratado foram de $50,49 \%$ e $62,18 \%$. 
Já ALHADAINY; HIMEL ${ }^{2}$, em 1994, avaliaram a capacidade das barreiras de SC para controlar a inserção do amálgama ou cimento de ionômero de vidro fotopolimerizável nas perfurações de furca e o efeito das barreiras na capacidade de selamento desses materiais. Perfurações de furca foram feitas no assoalho da câmara pulpar de 60 dentes molares, recém-extraídos, e depois seladas com amálgama sozinho, SC sob amálgama, ionômero de vidro fotopolimerizável sozinho e SC sob cimento ionômero. As aberturas foram preenchidas com resinas compostas, os dentes foram imersos em solução a $2 \%$ de $\beta$ eritrocina por duas semanas. Os dentes foram seccionados longitudinalmente para que fosse avaliada a penetração da solução corante por estereomicroscópio. Em cada secção, as medidas foram feitas do assoalho da câmara pulpar até o final da perfuração. O ionômero de vidro mostrou a menor infiltração, seguido pelo grupo do SC sob ionômero de vidro. Os grupos usando amálgama sozinho e SC sob amálgama mostraram a maior infiltração. A barreira de SC preveniu uma sobre-extensão dos materiais de reparo quando usados sob o amálgama e o ionômero de vidro.

Em 1996, NARY FILHO ; OKAMOTO ${ }^{73}$, estudaram a biocompatibilidade de implantes de Hapset ${ }^{\circledR}$ (hidroxiapatita associada ao sulfato de cálcio) em feridas de extração dental pela inserção em alvéolos de 20 ratos de tubos de polietileno, contendo em suas extremidades Hapset® e Guta-percha. Os animais foram sacrificados em períodos de 7, 15, 21 e 30 dias após as cirurgias e os espécimes obtidos, analisados microscopicamente. Verificou-se a reação mais severa na região contígua ao implante de Hapset, o que indica ser este material mais irritante do que a guta-percha. Na extremidade do tubo onde se inseriu Hapset ${ }^{\circledR}$, verificou-se uma resposta inflamatória mais intensa, desde os períodos iniciais, observando-se aí maior faixa de tecido conjuntivo com importante infiltrado inflamatório. Houve considerável atraso na organização dos tecidos próximos ao Hapset ${ }^{\circledR}$, com persistência do infiltrado e atraso na formação do trabeculado ósseo. No último período, o reparo alveolar junto à região 
cervical do grupo controle estava praticamente completo, com trabéculas ósseas bem formadas nas porções da crista alveolar. Próximo à Gutapercha, envolvida por fina cápsula fibrosa não infiltrada, foram evidentes pequenas trabéculas neoformadas. Junto ao material Hapset $₫$, ainda persistiu uma faixa de tecido conjuntivo pouco diferenciado com moderado número de linfócitos e macrófagos. O tecido ósseo neoformado restringiu-se ao "fundus alveolar", guardando uma distância considerável da extremidade do tubo. Os autores concluíram que o Hapset ${ }^{\circledR}$ mostrou-se irritante aos tecidos quando implantado em fendas de extração dental, promovendo atraso no reparo alveolar.

PAYNE et al. ${ }^{80}$, em 1996, determinaram a capacidade dos fibroblastos gengivais humanos, in vitro, de migrar através de um gradiente quimiotático sobre três diferentes barreiras para regeneração tecidual guiada: politetrafluoretileno, ácido poliláctico e sulfato de cálcio estéril. Foram divididas quarenta placas de Petri em 4 grupos iguais. Em cada grupo de 10 placas, um material de barreira diferente serviu de substrato de fibroblastos; como controle, utilizou-se o poliestireno. Aplicou-se uma técnica com agarose para medir a migração celular usando PDGF (fator de crescimento derivado de plaquetas) como um quimioatrativo e solução salina balanceada de Hank para testar a migração aleatória. Em seguida, foram cultivados fibroblastos diretamente em série triplicada nos materiais de barreira e numa superfície controle por 24 horas, sendo os grupos examinados por microscopia eletrônica de varredura. A análise comparativa dos dados da migração fibroblástica mostrou que a média da distância de migração para os controles foi significantemente maior do que em qualquer dos 3 materiais de barreira. A média de distância de migração sobre o sulfato de cálcio foi significantemente maior quando comparada à do grupo do ácido poliláctico. Todas as outras comparações possíveis entre os grupos não foram estatisticamente significantes. Exames por microscopia eletrônica de varredura dos fibroblastos cultivados diretamente nas membranas de barreira e comparados aos controles indicaram que o substrato de sulfato de 
cálcio facilitou a retenção e difusão celular, enquanto as células nas barreiras de politetrafluoretileno e de ácido poliláctico exibiram uma morfologia não útil para migração ou, em muitos casos, para saúde celular. Os autores concluíram que o sulfato de cálcio oferece o maior potencial para regeneração tecidual guiada em locais cirúrgicos onde a cicatrização por primeira intenção não pode ser obtida.

PECORA et al. ${ }^{84}$, em 1997, avaliaram o efeito do sulfato de cálcio como barreira para permitir a regeneração óssea por meio do princípio da osteopromoção. Foram utilizados quarenta ratos machos Sprangue-Dawley. Fizeram-se retalhos mucoperiostais bilateralmente vestibular e lingualmente na mandíbula para expor seus ângulos. Em seguida, foram criados defeitos ósseos de $5 \mathrm{~mm}$ bilateralmente. Essa dimensão de defeito foi escolhida por ser crítica, ou seja, nesse caso o defeito não se cicatriza espontaneamente durante a vida do animal, segundo a definição de Schmitz e Hollinger. No lado direito (teste), discos de SC pré-endurecidos e esterilizados foram aplicados vestibular e lingualmente para cobrir os defeitos. Discos feitos da mistura de SC com solução salina estéril foram colocados nos defeitos para cobrir $2 \mathrm{~mm}$ em toda a sua periferia. O lado esquerdo (controle) foi deixado sem material. Todos os retalhos foram suturados com material reabsorvível na porção muscular e com fio de seda na porção extra-oral. Os animais foram sacrificados em intervalos de 3, 9,18 e 22 semanas para observação. A análise microscópica demonstrou que em 3 semanas todos os locais de teste apresentavam cicatrização parcial (6 exemplares) e completa cicatrização óssea em 3 exemplares. Achados similares foram relatados nos outros períodos. O grupo controle não mostrou crescimento ósseo em 3 e 9 semanas e mostrou cicatrização parcial em 18 e 22 semanas. Os autores concluíram que o SC pode servir de barreira biológica.

SATO et al. ${ }^{97}$, em 1998, avaliaram a resposta osteogênica, na tíbia de coelho, de uma mistura de partículas de hidroxiapatita e SC. Essa mistura foi injetada na medula óssea de 30 tíbias e, como controle, foi injetado SC com 
solução salina. Sacrificaram-se cinco coelhos de cada grupo em intervalos de 2, 4, 8,12, 24 e 40 semanas após a injeção. Fez-se exame microscópico em 3 tíbias dos 5 animais sacrificados e análise por difração radiográfica da medula óssea em 2 tíbias remanescentes. Em duas das 3 tíbias, formaramse pontes de novo osso entre as partículas de hidroxiapatita e a cortical óssea, 4 semanas após a injeção da mistura de partículas de hidroxiapatita e SC. Nova formação óssea ocorreu em todas as três tíbias 8 semanas depois. Não se observou neoformação óssea nas tíbias do grupo controle. O índice de afinidade, um parâmetro de osteogênese, foi $0 \%$ na $2 .^{a}$ semana, $52,2 \%$ na $4 .^{\text {a }}$ semana, $74,8 \%$ na $8 .^{a}$ semana, $86,1 \%$ na 12 . $^{a}$ semana, $90,1 \%$ na 24 . $^{\text {a }}$ semana e $92,8 \%$ na 40 . $^{\text {a }}$ semana após a injeção. Foram encontrados aumentos estatísticos significantes nos índices de afinidade entre $2 .^{a}$ e $4 .^{a}$ semana e entre $4 .^{a}$ e $8 .^{a}$ semana, $p<0,03$ e $p<0,05$ respectivamente. Entre 12, 24 e 40 semanas, os índices mostraram tendências de crescimento. Difração radiográfica da medula óssea de 2 tíbias com a mistura ou com o SC sozinho mostrou que o mesmo desapareceu em 8 semanas após a injeção. Este experimento demonstrou que o SC é um veículo promissor, pois é absorvido em tempo curto, facilmente manipulado com partículas de hidroxiapatita e não interfere no processo de cicatrização óssea.

ALHADAINY $^{1}$ em 1998, avaliaram o uso de um material de hidroxiapatita básica e outro de SC, utilizados cada um sob um cimento de ionômero de vidro, como assoalho artificial para selar perfurações de furca. As perfurações do assoalho da câmara pulpar foram feitas em 72 dentes de 9 cachorros. Estes foram divididos em 3 grupos: grupo 1, selado somente com ionômero de vidro; grupo 2, selado com cimento ionômero de vidro sobre o assoalho artificial (matriz) de hidroxiapatita; e grupo 3, selado com cimento ionômero de vidro sobre o assoalho (matriz) de SC. Sacrificaram-se três cães em cada 3 intervalos (1, 3 e 6 meses). Avaliou-se a resposta tecidual clínica, radiográfica e microscopicamente. A hidroxiapatita mostrou o maior sucesso radiográfico, sendo seguida pelo SC e pelo ionômero de vidro. $\mathrm{Na}$ avaliação histológica, a maior taxa de sucesso foi de $67 \%$ para o 
SC, $62 \%$ para a hidroxiapatita e 59\% para o ionômero de vidro. Contudo, não houve diferença estatística significante entre o ionômero de vidro usado sozinho e o ionômero de vidro usado sobre uma barreira. Também não foi encontrada diferença significante entre a hidroxiapatita e o SC usados como assoalhos artificiais.

Em 1998, KIM et al. ${ }^{51}$, avaliaram a proservação de implantação cirúrgica de um composto de matriz óssea alogênica, seco e desmineralizado, com o sulfato de cálcio $(\mathrm{DBM}+\mathrm{SC})$ e de uma barreira de SC em defeitos intra-ósseos periodontais. Vinte e seis pacientes com 26 defeitos intra-ósseos profundos participaram do estudo. Treze pacientes receberam um implante $\mathrm{DBM}+\mathrm{SC}$ e treze, apenas cirurgia de retalho gengival (RGS-controle). A proservação clínica foi feita em 6 e 12 meses após a cirurgia. Em 12 meses após a cirurgia, a redução da profundidade (RP) para o grupo DBM+ SC e o grupo RGS foi de $4,3 \mathrm{~mm}$ e $3,0 \mathrm{~mm}$; o ganho de adesão clínica foi de 2,9 mm e 1,7 mm; o ganho de sondagem do nível ósseo foi de 2,9 $\mathrm{mm}$ e 1,2 $\mathrm{mm}$ respectivamente. Não houve diferença aparente entre as avaliações pós-cirúrgicas em 6 e 12 meses. Desenvolvimentos clínicos foram significantemente diferentes nas précirurgias de ambos os grupos, em ambos os intervalos de observação. Não houve diferenças significantes entre grupos na redução (RP) e no ganho de adesão clínica. Nível de ganho de sondagem óssea foi significantemente maior no grupo $\mathrm{DBM}+\mathrm{SC}$, quando comparado com o grupo controle. A implantação cirúrgica de DBM+SC com uma barreira de SC resultou em RP e o aumento do nível de inserção comparáveis aos conseguidos pela cirurgia de retalho gengival sozinha. Porém, o ganho na sondagem de níveis ósseos em bolsas periodontais profundas intra-ósseas foi maior do que o observado na cirurgia por retalho gengival sozinha.

WILKINS et al. ${ }^{116}$, em 1999, utilizaram o produto da combinação de matriz óssea desmineralizada, bioanalisada (AlloGro, AlloSource, DenverCO) e SC (Osteoset, Wright Medical Technology, Arlington TN) em 
50 pacientes que necessitavam de procedimentos de enxerto ósseo. Propuseram que a atividade osteoindutora da matriz óssea desmineralizada, combinada com a osteocondução e rápida dissolução das esferas de SC, poderia auxiliar na promoção de formação óssea. Os pacientes foram avaliados clínica e radiograficamente em intervalos regulares, pósoperatoriamente, por um clínico independente. Utilizou-se um total de 10 pontos de cicatrização para determinar características e progresso cicatriciais. Os autores trataram cinqüenta pacientes (24 homens e 26 mulheres) com lesões ósseas benignas (35), fraturas não-consolidadas (11), osteomielite (3) e fratura aguda (1). A idade média foi de 33 anos. As lesões foram localizadas em fêmur (16), tíbia (15), úmero (7) e outros locais (12). O tempo médio de controle foi de 14 meses (média 6 a 32 meses). Quarenta e nove de 50 pacientes (98\%) tiveram suas lesões cicatrizadas, num tempo médio de 18 semanas (3 a 48 semanas). Não foram encontradas complicações nos enxertos relatados. Os autores concluíram que a associação de matriz óssea desmineralizada bioanalisada e SC foi muito efetiva no tratamento de lesões benignas de osso e de fraturas nãocicatrizadas.

VENTURINI et al. ${ }^{111}$, em 1999, relatam um caso clínico em que empregaram o SC como membrana na resolução de um defeito ósseo severo na região superior esquerda. A paciente de 74 anos apresentava uma bolsa periodontal de $7 \mathrm{~mm}$ entre os elementos 24,25 e 26 e de $6 \mathrm{~mm}$ entre os elementos 23 e 24, com exsudato purulento. Procedeu-se à raspagem e ao alisamento radicular. Após 1 mês, a paciente ainda apresentava sangramento à sondagem nesta mesma região. Assim, seguiuse a fase cirúrgica. A paciente foi anestesiada, a incisão percorreu o sulco gengival iniciando no dente 22 e terminando em cunha distal no dente 26 . Havia um defeito ósseo em forma de cálice entre os dentes 23, 24, 25 e 26. As raízes foram novamente raspadas, alisadas com curetas Gracey e o tecido contaminado removido. Os defeitos foram preenchidos com osso liofilizado, usando-se como barreira o sulfato de cálcio sobre o osso. O 
retalho foi suturado e protegido com cimento cirúrgico sem eugenol. Após 10 dias, removeram-se as suturas e o cimento. Após 2 meses, a cicatrização já se completara e não havia mais sangramento ou exsudato purulento. Após 2 anos, a sonda periodontal não penetrou mais do que $2 \mathrm{~mm}$ em toda a região. Os autores concluíram que a regeneração tecidual guiada é uma técnica aceita na terapia periodontal para promover a nova inserção. O emprego de barreiras durante a cirurgia permite a proliferação do ligamento periodontal em direção à raiz exposta, bloqueando o epitélio e o conjuntivo. A associação de sulfato de cálcio ao enxerto ósseo, para preencher os defeitos ósseos, promoveu, assim, condição de saúde aos tecidos e higienização da região pela paciente, com profundidade de bolsa normal.

MITTAL ; CHANDRA ${ }^{68}$, em 1999, avaliaram a capacidade de vários materiais quando usados sobre uma barreira de SC para selar perfurações de furca. Foram usados 90 dentes molares humanos recém-extraídos, nãofusionados, bem desenvolvidos. As perfurações foram realizadas no assoalho da câmara pulpar. Os dentes foram divididos em um grupo controle e 5 grupos experimentais de 15 dentes cada. Nos grupos experimentais, barreiras de SC foram colocadas nas perfurações, as quais foram então seladas com amálgama de prata, ionômero de vidro, resina composta autopolimerizável, IRM ou AH26. Preencheram-se as aberturas com resina composta. Os dentes foram colocados dentro de uma solução de azul de metileno a $2 \%$ por 2 semanas. Depois foram seccionados, avaliados pela infiltração linear do corante e analisados estatisticamente. Observou-se uma penetração máxima do corante no amálgama, seguido em ordem decrescente pelo ionômero de vidro, resina composta, IRM e AH26. O AH26 mostrou a melhor capacidade de selamento na presença da barreira de SC, seguido pelo IRM, resina composta e ionômero de vidro. O amálgama mostrou a pior capacidade de selamento quando usado para selar perfurações de furca. 
Utilizando defeitos criados na tíbia de coelhos, MACNEIL et al. ${ }^{60}$, em 1999, compararam o comportamento biológico de 4 materiais sintéticos: hidroxiapatita $(\mathrm{HA})$, Sulfato de cálcio $\left(\mathrm{CaSO}_{4}\right)+$ osso autógeno, biovidro com partículas de 300-360 $\mu \mathrm{m}$ (BG1) e biovidro com 90-710 $\mu \mathrm{m}$ (BG2). Para controle negativo, um defeito foi deixado vazio e, para controle positivo, um outro defeito foi preenchido com osso autógeno. Os animais foram sacrificados aos 28 dias pós-cirúrgicos. Secções histológicas foram obtidas e a porcentagem de formação de osso novo para cada material foi determinada por análise de imagem computadorizada. BG1 41,82\%, BG2 $40,36 \%$, HA $41,83 \%$ e SC + osso autógeno 58,83\%. O controle negativo apresentou $41,95 \%$ e controle positivo, 50,41\%. Os resultados mostraram ausência de células inflamatórias, contudo espécimes de HA, BG1 e BG2 exibiam algumas células gigantes e pouca evidência de reabsorção. A conclusão desse estudo é que o material sintético pode suportar a formação óssea em defeitos criados cirurgicamente.

Em 2000, AL RUHAIMI², avaliou o potencial osteogênico do Capset, Ostegraf e BOP (Biocompatible Osteoconductive Polymer) empregados isoladamente e associados entre si, em fêmures de coelhos. Foram empregados 10 coelhos machos New Zealand, pesando em torno de 3,5 kg e 2 coelhos para o grupo controle. Defeitos ósseos de $5 \mathrm{~mm}$ de diâmetro por $8 \mathrm{~mm}$ de profundidade foram confeccionados com brocas nos côndilos medianos de ambos os fêmures, num total de 20 cavidades ósseas. Estas foram divididas em 5 grupos experimentais, sendo 4 cavidades para cada grupo. O grupo controle foi preenchido com o coágulo. O grupo 1 foi preenchido com Osteograf, o 2 com BOP, o 3 com Capset, o 4 com Osteograf + capset e o 5 com BOP + capset. Após 8 semanas os animais foram sacrificados, os fêmures foram dissecados e seccionados em blocos. Os resultados mostraram que a mistura do SC com materiais de enxerto acelerou a osteogênese e aumentou a calcificação e a quantidade de novo osso num curto período de tempo. Contudo, não é recomendado usar o SC sozinho como um material preenchedor. 
PECORA et al. $^{85}$, em 2000, empregaram o SC como barreira mecânica, em 20 pacientes com idade variando entre 28 e 65 anos, após a apicetomia. As lesões foram classificadas como do tipo II (lesões que se estendem sobre a raiz). O retropreparo apical foi realizado com ultra-som e a obturação retrógrada com Super EBA. Posteriormente foi colocado o SC (Surgiplaster) em camadas comprimidas com gazes, sendo o retalho reposicionado e suturado. O controle radiográfico foi realizado aos 0 , 3, 6, 9 e 12 meses, por 3 endodontistas, que não sabiam se os casos eram teste ou controle. Após 6 meses, no grupo em que se usou o SC, a cura completa foi de $70 \%$, a incompleta (escara), 20\%, a incerta, 5\%, e a insatisfatória, $5 \%$. Os autores deduziram nesse estudo clínico que os melhores resultados nos casos teste se devem à presença do SC, que é um material não-tóxico, totalmente reabsorvível, fácil de usar e que, além disso, custa menos do que outros materiais.

Em 2001, PECORA ${ }^{83}$, avaliaram o uso de SC (Surgiplaster) no tratamento cirúrgico de lesões perirradiculares em forma de túnel. Foram selecionados 20 pacientes que radiograficamente mostravam evidências de lesões perirradiculares maiores que $10 \mathrm{~mm}$, com falta da cortical óssea lingual e vestibular. Dez pacientes foram tratados com apicetomia, obturação retrógrada e enxerto de SC no defeito ósseo. Outros dez pacientes receberam o mesmo tratamento cirúrgico, porém sem o enxerto de SC. A avaliação do processo de reparo foi feita 6 e 12 meses após a cirurgia. Os resultados clínicos, após 12 meses, mostraram que em 7 dentes houve um reparo completo e em 2 dentes, incompleto; o grupo controle mostrou 3 dentes com completo reparo, 5 com reparo incompleto e 1 com reparo insatisfatório. Um dente de cada grupo foi extraído, em decorrência de fratura vertical, durante a proservação. Os resultados desse estudo clínico mostraram ser eficaz a adição de SC como enxerto ósseo durante o tratamento cirúrgico convencional das lesões do tipo túnel. 
SU-GWAN et al. ${ }^{108}$, em 2001, avaliaram o implante de um composto de partículas de dentina, SC (GP) e um osso xenógeno (Bio-Oss) na calvária de rato. Foram utilizados 40 ratos, aleatoriamente divididos em 5 grupos e cada grupo subdividido em 2 subgrupos. Os defeitos foram preenchidos com diferentes materiais de implante em cada grupo. No grupo 1 os defeitos foram preenchidos com partículas de dentina e SC na proporção de 2:1; no grupo 2, foram preenchidos com partículas de dentina, SC e Bio-Oss, usando-se a proporção de 2:1:1; no grupo 3, os defeitos foram preenchidos com SC e Bio-Oss; no grupo 4, foram preenchidos somente com Bio-Oss; o grupo 5 serviu como controle. Os animais foram sacrificados 8 e 16 semanas após a cirurgia. Após os procedimentos laboratoriais, os defeitos foram analisados histomorfometricamente. Os resultados mostraram que houve formação óssea mais alta no grupo 4, seguido do grupo 3, depois do grupo 2 e do grupo 1 . Os autores concluíram que a combinação de partículas de dentina e SC é uma alternativa para substituição óssea, apesar de ser menos efetiva do que o Bio-Oss.

Em 2002, APAYDIN ; TORABINEJAD ${ }^{8}$, avaliaram o efeito do sulfato de cálcio sobre a deposição de cemento e o reparo ósseo após cirurgia perirradicular. Foram empregadas 24 raízes de pré-molares inferiores de cães Beagle com 2 anos de idade. Após duas semanas do tratamento endodôntico, realizou-se a cirurgia periapical. O MTA foi usado como material retrobturador. Em um grupo a cavidade cirúrgica foi preenchida com o SC (Capset, Lifecore Biomedical) e no outro não houve adição de nenhum material. Os animais foram sacrificados após 4 meses. O tecido mineralizado da cicatrização foi analisado histomorfometricamente. Todas as raízes mostraram evidência de deposição de cemento adjacente ao material retrobturador e regeneração óssea nos locais onde foi realizada a osteotomia. O reparo ósseo adjacente à retrobturação foi de 53,08\% sem o sulfato de cálcio e de 54,63\% com o sulfato de cálcio. A análise estatística, com o teste de Mann-Whitney, mostrou uma diferença estatística de nível 0,05 . Os autores concluíram que a colocação de sulfato de cálcio na 
osteotomia após a cirurgia perirradicular não afetou a deposição de cemento e o reparo ósseo.

STROCCHI et al. ${ }^{106}$, em 2002, avaliaram a presença de vasos sangüíneos e a contagem de microvasos, por meio da DMV (densidade de microvasos), em locais tratados com osso autógeno e SC, com ou sem a presença de membrana não-reabsorvível (Goretex), em tíbias de coelhos. Foram empregados no experimento 9 coelhos adultos. Os autores confeccionaram 3 defeitos ósseos de $6 \mathrm{~mm}$ de largura, em cada metáfise da tíbia. Os defeitos foram preenchidos aleatoriamente. Os defeitos do grupo 1 (3 coelhos) foram preenchidos com SC (Surgiplaster, Classimport, Itália) e cobertos com membrana; os do grupo 2 ( 3 coelhos) foram preenchidos com SC; os do grupo 3 (3 coelhos) foram preenchidos com osso autógeno. Foram preenchidos 54 defeitos: $18 \mathrm{com}$ SC + Goretex, $18 \mathrm{com}$ SC e $18 \mathrm{com}$ osso autógeno. Não houve nenhuma complicação no pós-operatório. Todos os 9 coelhos foram sacrificados após 4 semanas do procedimento cirúrgico. Os resultados do MVD foram os seguintes: Grupo 1, 19,88; grupo 2, 7,92; grupo 3, 5,56. Houve uma diferença estatística entre os grupos 1 e 3, 1 e 2, 2 e 3 . A presença de mais vasos sangüíneos nos locais tratados com SC poderia ajudar a explicar os bons resultados relatados na literatura.

YOSHIKAWA et al. ${ }^{114}$, em 2002, estudaram a regeneração óssea, em cães da raça Beagle, empregando as membranas reabsorvíveis e nãoreabsorvíveis sobre defeitos ósseos preenchidos com SC após a apicetomia. As raízes do $3 .^{\circ}$ e $4 .^{\circ}$ pré-molar inferior, de 12 cães Beagle, foram tratadas e apicetomizadas, sendo então divididas aleatoriamente em 5 grupos. $O$ grupo A foi recoberto com a membrana e-PTFE; o grupo B, com PGLA; o grupo C, com colágeno; o grupo $\mathrm{D}$, com SC e o grupo $\mathrm{E}$, controle, foi preenchido com coágulo. Os cães foram sacrificados 4, 8 e 16 semanas após a cirurgia. As peças foram desmineralizadas $\mathrm{e}$ os cortes foram analisados histomorfometricamente. Os resultados mostraram uma nova cortical óssea formada fechando o defeito ósseo em 16 semanas. Nos grupos A e D a 
porcentagem de regeneração foi significativamente menor do que no grupo $B(p<0,01)$. A porcentagem de osso regenerado no grupo $A$ foi significativamente maior do que no grupo $B$; no grupo $D$, foi significativamente maior do que nos grupos B e E. Segundo os autores, os resultados sugerem que a membrana e-PTFE é mais efetiva comparada à membrana reabsorvível e ao grupo controle e que, na regeneração óssea pós- apicetomia, o sulfato de cálcio pode substituir a e-PTFE.

MURASHIMA et al. $^{71}$, em 2002, fizeram uma investigação sobre o efeito de SC (Surgiplaster, Itália) em conjunção com a apicetomia sobre vários defeitos ósseos. Foram usados o $3 .^{\circ}$ e o $4 .^{\circ}$ pré-molares inferiores de 11 cães Beagle. Após o tratamento de canal e a apicetomia, foram preparados 3 tipos de defeitos ósseos em ambos os lados da mandíbula. $\mathrm{O}$ tipo I, com comunicação com o sulco gengival; o tipo II, defeito ósseo extenso abrangendo duas raízes e o tipo III, defeito ósseo do tipo túnel. O lado experimental foi locado aleatoriamente e os defeitos ósseos foram preenchidos com SC (Surgiplaster). Os defeitos ósseos do lado oposto foram deixados vazios e serviram de controle. Os animais foram sacrificados 8 e 16 semanas após a cirurgia. As peças foram desmineralizadas e avaliadas histomorfometricamente. Os resultados mostraram que, no defeito do tipo I, não foi observada formação de osso do lado vestibular da raiz, em nenhum dos espécimes de 8 e 16 semanas. Nos defeitos ósseos de tipo II e III, o volume de osso e tecido formado foi maior do que no grupo controle $(P<0,001)$. Do mesmo modo, o valor padrão da aposição mineral do lado experimental foi significantemente maior do que do lado controle. Os autores concluíram que o uso de SC foi mais efetivo na regeneração óssea dos defeitos do tipo túnel e com perda óssea extensa do que na dos defeitos com comunicação com o sulco gengival.

$M L_{L L O}^{68}$, em 2003, avaliou histologicamente o uso de partículas de vidro bioativo de tamanho reduzido, associado ao SC, como barreira, em defeitos cirúrgicos realizados em tíbias de ratos. Para o estudo, foram 
utilizados 64 ratos, divididos em 4 grupos. O grupo controle teve os defeitos preenchidos por coágulo sangüíneo; o grupo 1, somente por SC; o grupo 2, pelo vidro bioativo e o grupo 3, por vidro bioativo mais a proteção de SC. Foi preparada uma cavidade cirúrgica medindo $4 \mathrm{~mm} \times 2 \mathrm{~mm}$ na face lateral da tíbia direita de cada rato. Os tecidos foram reposicionados e suturados. Os animais foram sacrificados aos 10 e 30 dias pós-operatórios. As peças foram processadas laboratorialmente para análise em microscópio óptico e os resultados submetidos à análise estatística. Aos 10 dias, a porcentagem média de neoformação óssea foi: para o grupo controle, 32,17\%, para o grupo SC, $10,33 \%$, para o grupo VB, $6,47 \%$ e para o grupo VB/SC, $8,34 \%$. Aos 30 dias, a porcentagem média foi, para o grupo controle, 59,51\%, para o grupo SC, 46,02\%, para o grupo VB, 19,36\%, e para o grupo VB/SC, $44,70 \%$. Mello concluiu que o grupo controle apresentou significativamente maior neoformação óssea que os grupos experimentais em ambos os períodos pós-operatórios. Aos 10 dias pós-operatórios, os grupos experimentais SC, VB e VB/SC não apresentaram diferenças significativas entre si, em relação à quantidade de osso neoformado. Aos 30 dias os grupos experimentais em que se empregou a barreira de SC apresentaram significativamente maior neoformação óssea do que o grupo somente com as partículas de vidro bioativo.

Em 2004, ORSINI et al. ${ }^{78}$, avaliaram o reparo do defeito ósseo em metáfise de coelho empregando o SC em forma de partículas e cimento. Oito coelhos New Zealand, pesando aproximadamente de 2,5 a $3 \mathrm{~kg}$, foram usados nesse estudo. Em cada coelho foram confeccionados 4 defeitos, de $6 \mathrm{~mm}$, na metáfise da tíbia. Dois defeitos na tíbia direita foram preenchidos com SC em forma de cimento, e os outros dois do lado esquerdo foram preenchidos com SC em partículas. Quatro coelhos foram sacrificados em 2 semanas e os outros quatro, em 4 semanas. As peças foram preparadas para análise microscópica. Na primeira fase do preparo foi possível observar uma intensa atividade osteoblástica, em algumas áreas a matriz osteóide estava presente. Após 2 semanas o SC (particulado e cimento) estava 
presente juntamente com os fluidos biológicos e as células dentro do defeito ósseo. Foi observado um preenchimento por um novo osso em torno de $10 \%$ dos defeitos. Após 4 semanas o SC foi completamente reabsorvido e aproximadamente $34 \%$ dos defeitos estavam preenchidos por osso neoformado. Não havia células inflamatórias em nenhum dos espécimes. Não foram encontradas diferenças estatísticas com relação ao uso do SC em partículas ou cimento. Ambos mostraram alta biocompatibilidade, promoveram a osteocondução na neoformação óssea e não induziram nenhum efeito desfavorável no processo da regeneração óssea.

GUARNIERI et al. ${ }^{40}$, em 2004, avaliaram histologicamente os alvéolos dentais de 10 pacientes, a fim de observar a ação do Surgiplaster aplicado após exodontias. Cinco alvéolos foram usados como grupo experimental e cinco como grupo controle. Após 3 meses, os pacientes tanto do grupo experimental, que tiveram os defeitos preenchidos com Surgiplaster, como do grupo controle foram submetidos a uma nova cirurgia para colocar os implantes. Por meio de uma trefina de $2,5 \mathrm{~mm}$ de diâmetro, o tecido ósseo foi removido e analisado histomorfometricamente. Não foram observados traços do Surgiplaster em nenhum dos espécimes. Os resultados mostraram que não houve uma diferença estatística significante. Os autores concluíram que o Surgiplaster é ideal para ser usado como implante após exodontias, por ser reabsorvível e permitir o crescimento de um novo osso em 3 meses.

\section{CARACTERÍSTICAS DO SULFATO DE CÁLCIO}

\section{Gesso Paris (Plaster of Paris)}

Durante a Idade Média, o gesso foi muito difundido, principalmente na França. A lenda atribui sua descoberta a um pastor de Montmartre que, ao construir com pedras de gesso uma fornalha ao ar para cozinhar alimentos, 
observou que estas se desfaziam pela ação do calor e, pela hidratação, voltavam a se solidificar, após a chuva. Até hoje, a França é bastante conhecida pelas suas jazidas de gesso muito puro, o qual recebe a denominação de "gesso de Paris" (Soares dos Santos ${ }^{102}$,1983).

A gipsita é um mineral encontrado em várias partes do mundo. Quimicamente, é usado para fins odontológicos basicamente como sulfato de cálcio di-hidratado $\left(\mathrm{CaSO}_{4} .2 \mathrm{H}_{2} \mathrm{O}\right)$.

Sulfato de cálcio hemi-hidratado é o resultado da calcinação do sulfato de cálcio di-hidratado (submetido a temperaturas que variam de $110^{\circ}$ $\mathrm{C}$ a $\left.120^{\circ} \mathrm{C}\right)$.

$\mathrm{CaSO}_{4} \cdot 2 \mathrm{H}_{2} \mathrm{O} \Longrightarrow 110^{\circ} \mathrm{C}-120^{\circ} \mathrm{C} \Longrightarrow \mathrm{CaSO}_{4} \cdot 1 / 2 \mathrm{H}_{2} \mathrm{O}$ (SC hemi-hidratado)

$\Longrightarrow 130^{\circ} \mathrm{C}-200^{\circ} \mathrm{C} \Longrightarrow \mathrm{CaSO}_{4}$ anidro

Sulfato de cálcio monohidratado - apenas uma molécula de água. (ANUSAVICE ${ }^{7}, 1998$ )

Segundo WIRSCHING ${ }^{118}$, em 1993, o sulfato de cálcio constitui o gesso, que é um mineral comum, amplamente distribuído na Terra. Não é encontrado somente em regiões vulcânicas. Grandes quantidades de gesso são obtidas por meio de processos industriais. Nesses casos, o sulfato de cálcio é usualmente obtido na forma de pó fino.

O gesso é útil como material industrial, pois perde rapidamente sua água de hidratação quando aquecido, produzindo parcial ou totalmente gesso calcinado, para logo reverter ao di-hidratado original quando a água é adicionada novamente a ele. Estes dois fenômenos, a desidratação e a reidratação, são as bases da tecnologia do gesso (WIRSCHING ${ }^{118} 1993$ ).

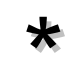


3

Proposição 


\section{PROPOSIÇÃO}

O objetivo deste trabalho foi avaliar histologicamente a resposta tecidual do sulfato de cálcio dihidratado (Merck), Capset (sulfato de cálcio hemi hidratado) e Surgiplaster quando implantados em cavidade cirúrgicas , em epífises de fêmures de coelhos. 
4

Material e Métodos 


\section{MATERIAIS E MÉTODOS}

\subsection{Animais}

Para a realização deste trabalho foram utilizados 20 coelhos machos, adultos brancos, da raça Nova Zelândia (Oryctologos Cunicular), com o peso médio de 3,5 kg a 4,0 kg, idade entre 9 e 12 meses, procedentes do biotério da Faculdade de Medicina Veterinária de Botucatu da UNESP. Os animais apresentavam funções vitais normais e foram mantidos durante todo o período experimental isolados em gaiolas individuais, em boas condições ambientais de alimentação, temperatura, higiene e iluminação. Os coelhos foram divididos em 4 grupos de 5 animais. Em cada coelho foram confeccionadas duas cavidades cirúrgicas em cada fêmur para posterior preenchimento com os biomateriais em questão.

\subsubsection{Anestesia}

Para os procedimentos experimentais, os animais foram submetidos à anestesia geral com injeção intramuscular de pré-anestésico Rompum (cloridrato de xilasina) a uma dose de 0,1 ml/kg de peso corporal, seguido de Ketalar (cloridrato de cetamina) a uma dose de $0,5 \mathrm{ml} / \mathrm{kg}$ de peso corporal. 


\subsubsection{Incisão e Sindesmotomia}

Após a anestesia realizou-se a tricotomia na parte interna da região entre o fêmur e a tíbia, seguida de uma anti-sepsia abundante com Povidine (polivinilpirrolidona). Efetuou-se uma incisão linear, com a lâmina para bisturi $n^{0} 15$, na região interna da junção da tíbia com o fêmur, seguida de uma cuidadosa sindesmotomia ou divulsão total (pele+periósteo) com 0 sindesmótomo de Mölt, até que fosse visualizado o tecido ósseo do fêmur, local determinado para confeccionar o defeito ósseo.

\subsubsection{Enxertos e a Técnica Cirúrgica}

Foram realizadas 4 cavidades cirúrgicas, duas em cada fêmur (diâmetro aproximado de $5 \mathrm{~mm}$ e profundidade de $8.0 \mathrm{~mm}$ ), com uma trefina n. ${ }^{\circ} 3$ (Fig. 1), acoplada no contra- ângulo, e com auxílio do micromotor elétrico Nouvag, na velocidade de 3.000 rpm. A primeira cavidade foi feita na região mais próxima da epífise e a segunda, mais distalmente.

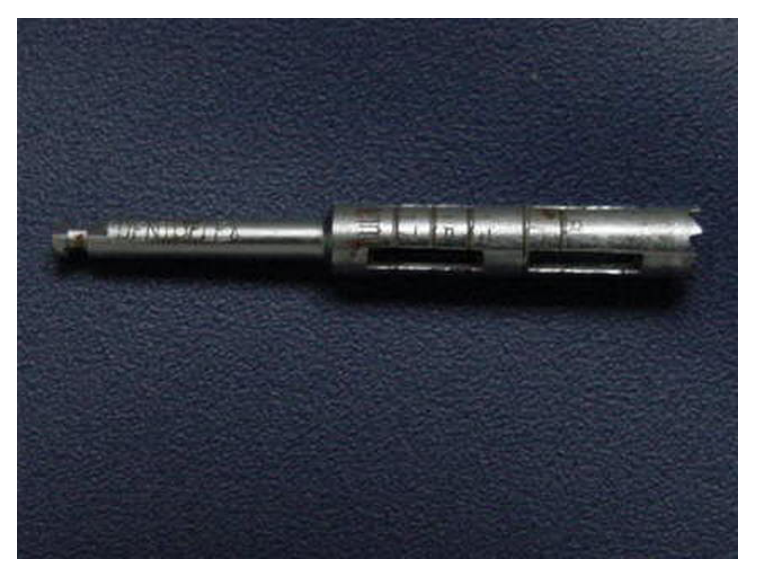

FIGURA 1 - Trefina n. ${ }^{\circ} 3$ da Dentoflex, para confecção da cavidade cirúrgica. 
Estas cavidades foram confeccionadas sob irrigação constante de solução salina estéril. A distância entre as duas cavidades correspondeu aproximadamente a $10 \mathrm{~mm}$ (fig.2).

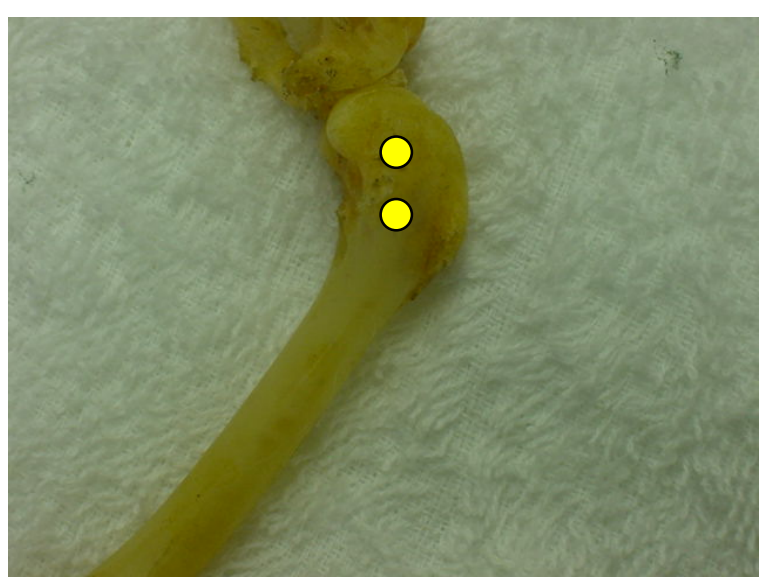

FIGURA 2 - Local das duas cavidades cirúrgicas

Nas cavidades preparadas foram cuidadosamente inseridos os seguintes materiais: Sulfato de cálcio di-hidratado*, Capset** e Surgiplaster $^{\star \star \star}$. Uma das cavidades foi preenchida com sangue, servindo como controle.

QUADRO 1 - Distribuição dos materiais nas cavidades cirúrgicas dos animais

\begin{tabular}{|c|c|c|c|c|c|}
\hline & & \multicolumn{4}{|c|}{ Períodos } \\
\hline Grupo & Materiais & 30 dias & 60 dias & 90 dias & 180 dias \\
\hline 1 & SC P.A. & 6 & 6 & 6 & 6 \\
\hline 2 & Capset & 6 & 6 & 6 & 6 \\
\hline 3 & Surgiplaster & 6 & 6 & 6 & 6 \\
\hline 4 & Controle & 2 & 2 & 2 & 2 \\
\hline
\end{tabular}




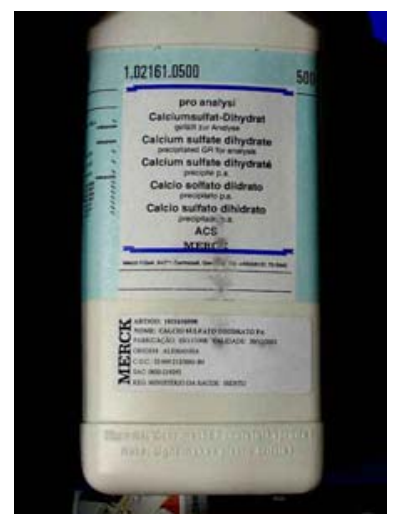

FIGURA 3 - Sulfato de cálcio di-hidratado* - Merck do Brasil

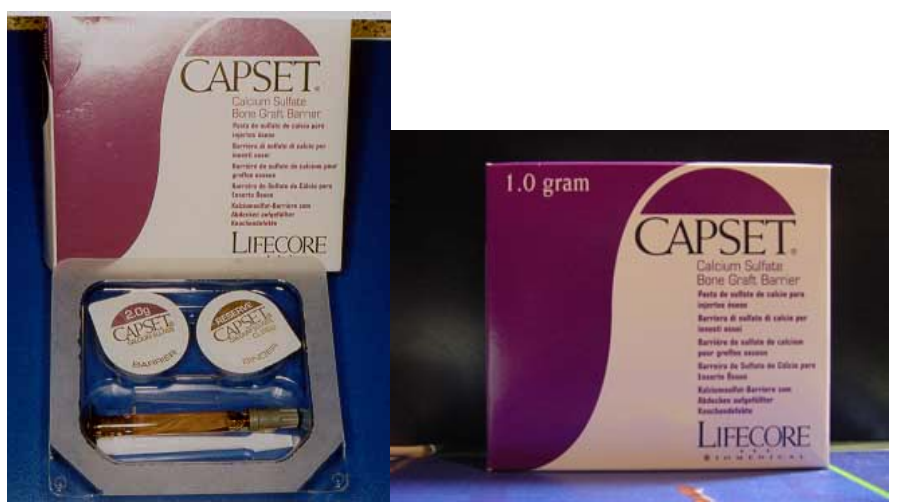

FIGURA 4 - Apresentação comercial do Capset**

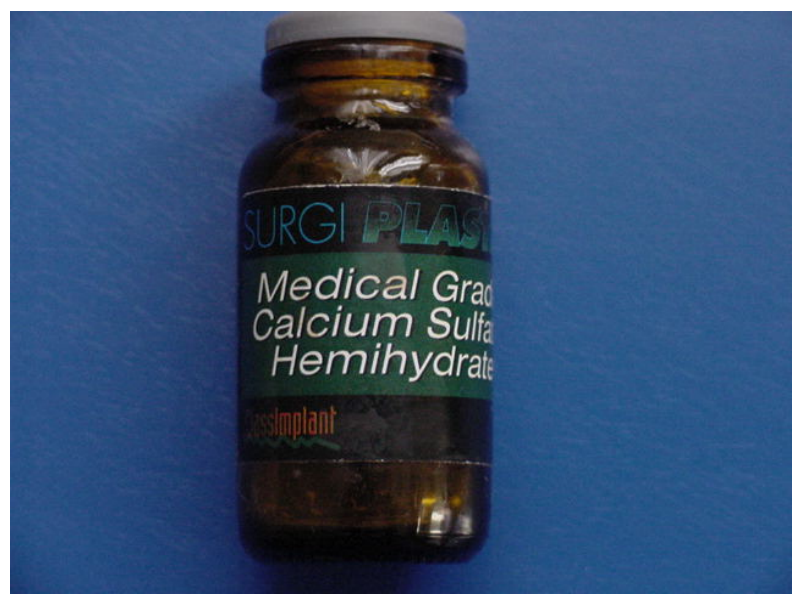

FIGURA 5 - Apresentação comercial do Surgiplaster ${ }^{\star \star \star}$

*Sulfato de cálcio di-hidratado - Merck do Brasil

${ }^{* *}$ Capset - Lifecore Biomedical USA

***Surgiplaster - Medical grade calcium sulfate hemihydrate. Classimport Italy 
Foi realizado um rodízio entre as cavidades para inserção dos materiais, alternando-se os fêmures direito e esquerdo.

Os materiais (Capset, Surgiplaster e SC di-hidratado (Merck)) foram proporcionados e misturados com o próprio sangue do coelho, retirado do lóbulo da orelha. (Fig. 6)

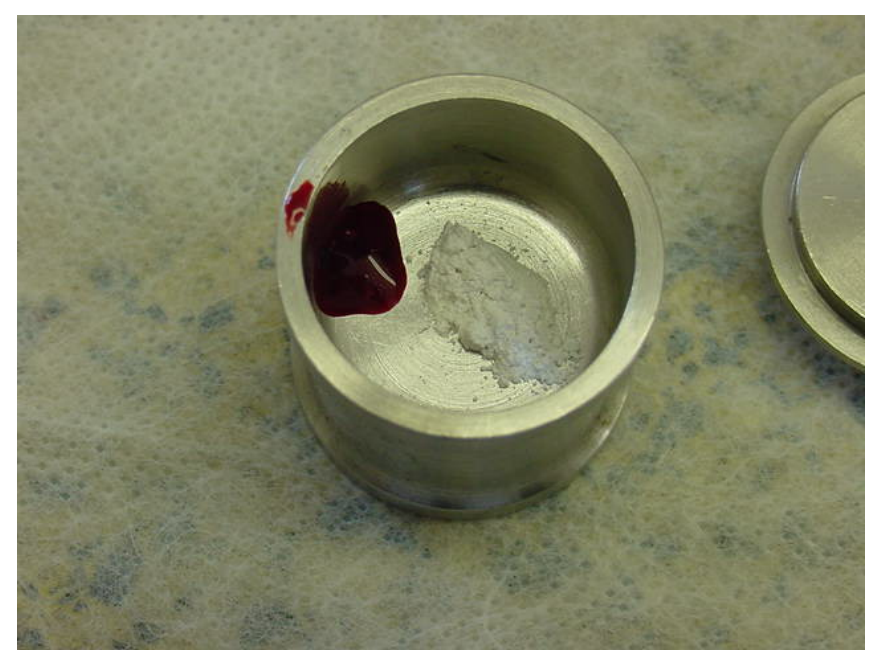

FIGURA 6 - Sangue + sulfato de cálcio

Para o preenchimento das cavidades foi utilizado um porta-enxerto especial, estéril e descartável, confeccionado a partir de uma seringa para insulina de 1cc, cuja ponta foi recortada. (Fig. 7)

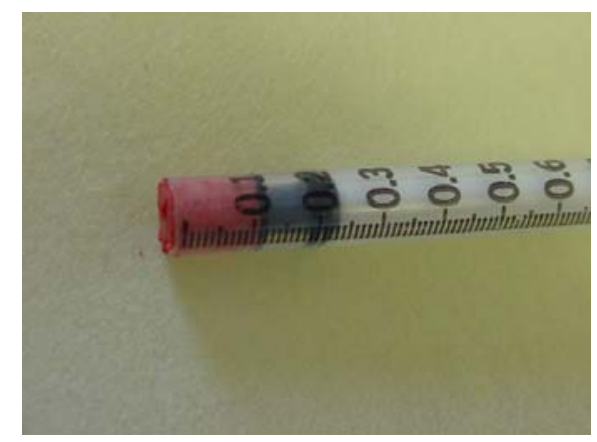

FIGURA 7 - Porta-enxerto adaptado com o material para ser levado à cavidade 


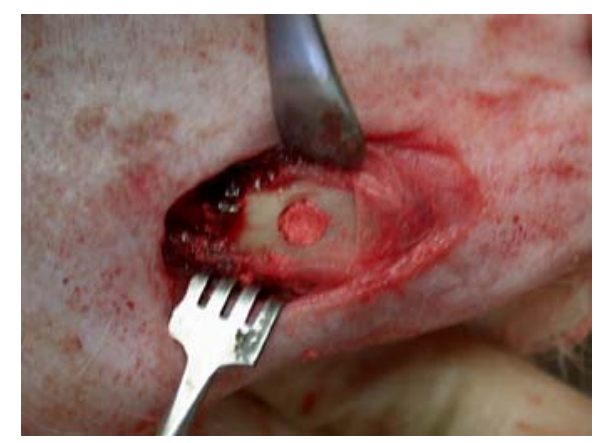

FIGURA 8 - Cavidade cirúrgica preenchida com o sulfato de cálcio

\subsubsection{Procedimento de Sutura}

Após a colocação dos materiais, os retalhos foram reposicionados de modo a não ficarem sob tensão. A sutura foi iniciada na parte referente à musculatura, com pontos simples, utilizando-se fio Vicryl 4.0* (absorvível) com agulha atraumática. A parte correspondente à derme do animal foi suturada com fio de seda Ethicon $4.0^{* *}$, removido sete dias após a cirurgia. Terminada a sutura, foi feita uma anti-sepsia com povidine ${ }^{\star \star *}$ no local da sutura e o animal foi acomodado onde pudesse descansar e recuperar-se da anestesia.

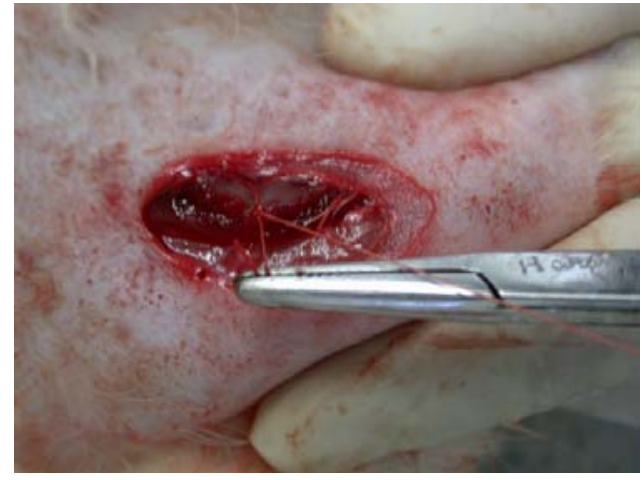

FIGURA 9 - Sutura interna (Vicryl)

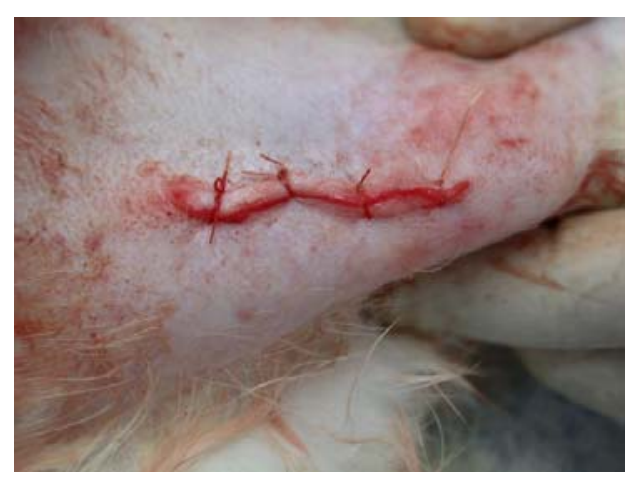

FIGURA 10 - Sutura externa(seda)

*Vicryl - poliglactina 910 Ethicon Johnson \& Johnson

**Ethicon - Johnson \& Johnson

***Povidine - PVPI (polivinilpirrolidona-iodo - Johnson) 
Após 3 horas de retorno à normalidade, o animal foi colocado de volta na gaiola individual.

\subsubsection{Período de Preservação}

Imediatamente após o procedimento cirúrgico, os animais receberam aplicações intramusculares de $0,8 \mathrm{ml} / \mathrm{kg}$ de peso, por dia, de antibiótico Flotril (enrofloxacina) 2,5\%, por 5 dias após a cirurgia, e antiinflamatório Banamine (Flonexin Meglumine) injetável na dose de $0,2 \mathrm{ml} / \mathrm{kg}$ de peso, por dia, durante 4 dias após a cirurgia.

Durante todo o período experimental foram alimentados com ração sólida e água e continuaram isolados em gaiolas individuais, sob as mesmas condições ambientais a que estavam submetidos anteriormente à cirurgia.

Os animais foram mortos 30, 60, 90 e 180 dias após a cirurgia, com uma overdose intravenosa de barbitúricos diluídos em solução salina, injeção intraperitonial letal de Tiopental sódio, numa dosagem de 200 mg/kg.

\subsubsection{Preparo das Peças}

Após a morte dos animais, os fêmures foram removidos e dissecados. Nesse momento, as regiões correspondentes aos enxertos foram cuidadosamente separadas dos tecidos adjacentes, cortadas e removidas. As regiões expostas foram examinadas atentamente para o registro de eventuais sinais macroscópicos de inflamação e infecção. Procedeu-se então a sua imersão em formol tamponado a 10\%, pH 7.2, durante uma semana. 


\subsubsection{Procedimento Histotécnico}

Descalcificação

As amostras foram lavadas em água corrente durante 2 horas para remoção do excesso de fixador, prosseguindo-se então com a descalcificação em solução de Morse** (citrato de sódio a 20\% e ácido fórmico a 50\% na proporção de 1:1), por um período de 40 dias.

Para avaliar o grau de descalcificação das peças, foram realizadas tomadas radiográficas convencionais, para verificar se a imagem mostrava alguma radiopacidade indicativa de mineralização. As peças foram radiografadas pelo aparelho de raios-X Dabi-Atlante Spectro 70X, no sentido longitudinal (dos defeitos ósseos), a uma distância de $30 \mathrm{~cm}$, com exposição de 0,12 seg. e processo de revelação radiográfica conforme o tempo e temperatura recomendados. Realizou-se também teste de dureza da peça, introduzindo-se uma pequena agulha no osso.

Após a descalcificação, as peças foram submetidas aos procedimentos histotécnicos:

a) lavagem em água destilada, por 24 horas;

b) banho de etanol a 70\%, 24 horas;

c) banho de etanol a $80 \%$, por uma hora;

d) banho de etanol a 90\%, por uma hora;

e) banho de etanol a 95\%;

f) dois banhos de uma hora em etanol a 100\%;

g) banho de etanol a 100\% durante 24 horas;

h) banho de 30 minutos em xilol;

i) banho de uma hora em xilol. 


\subsubsection{Inclusão}

As peças foram embebidas em Histosec (parafina + resina plástica), por 24 horas a $58^{\circ}$.C, em estufa, com quatro trocas. Em seguida, procedeuse à inclusão para a obtenção dos blocos. Os espécimes foram orientados de forma a permitir cortes longitudinais envolvendo osso cortical, medular e enxerto em uma mesma lâmina.

\subsubsection{Corte dos Espécimes}

Os cortes foram realizados pelo micrótomo rotatório da MICROM HM $340 \mathrm{E}$, obtendo-se cortes semi-seriados, com 6 micrometros de espessura. Em seguida, realizou-se a identificação das lâminas.

\subsubsection{Coloração}

Após o corte, os espécimes foram corados com a técnica da Hematoxilina e Eosina.

Coloração com Hematoxilina e Eosina

O procedimento de coloração consistiu na imersão em xilol (1) por 10 minutos, seguida de imersão em xilol (2) por 10 minutos. Prosseguiu-se com passagens sucessivas pelo álcool-xilol (1:1), álcool absoluto, álcool 70\% e por fim água deionizada, por um período de 5 minutos cada banho. 
Após a passagem nessas soluções, foi feita a coloração em hematoxilina de Harris por 1 minuto, seguida de outra lavagem (viragem) em água corrente por 7 minutos, imersão em eosina por 30 segundos e lavagem em água corrente para remover os excessos. Seguiu-se uma rápida imersão em álcool 95\% e em álcool absoluto por 1 minuto, passagem por álcool por 5 minutos, por álcool xilol por 5 minutos, por xilol por 5 minutos e, finalmente, imersão em outra solução de xilol até montagem das lamínulas com bálsamo do Canadá e secagem em estufa por 3 horas.

\subsubsection{Análise Microscópica}

Os cortes histológicos foram analisados em microscópio óptico binocular da marca Olympus $\mathrm{CH} 2$.

$\mathrm{Na}$ análise microscópica efetuada procurou-se observar os seguintes fenômenos:

a- Infiltrado inflamatório, a intensidade e a localização

b- Extensão do coágulo sangüíneo

c- Formação e desenvolvimento ósseo (imaturo e maduro) e a sua organização.

d- Reabsorção do material implantado

e- Fechamento completo ou incompleto do defeito ósseo. 
5

Resultados 


\section{RESULTADOS}

\subsection{Análise Morfológica}

a) Período de 30 dias

Nos defeitos preenchidos com coágulo sangüíneo ocorreu a formação de um tecido ósseo primário em forma de calota, que fechou a abertura da cavidade. Na região voltada para o canal medular ocorreu a formação de finas trabéculas ósseas entremeadas com tecido conjuntivo (Fig. 11a). Entre as bordas da ferida havia pouca formação óssea.

Tecido ósseo em forma de calo apresentava-se recoberto por um denso periósteo (Fig. 11f). Em nenhum dos defeitos houve invaginação do tecido conjuntivo para seu interior.

Os defeitos tratados com Surgiplaster exibiram duas pequenas faixas de tecido ósseo primário (Fig. 12a), das quais a externa tinha aspecto contínuo e a interna, aspecto fragmentado, no espaço entre as duas havia tecido conjuntivo sendo substituído por tecido mielóide. Entre as bordas do defeito observou-se uma pequena área óssea, que contudo não fechava o defeito e tinha uma espessura bem menor do que a borda do osso original. $\mathrm{Na}$ parte mais interna da cavidade havia algumas trabéculas ósseas 
entremeadas por grande quantidade de tecido mielóide (Fig. 12c), ou ainda traves ou pequenas formações ósseas envolta por um tecido rico em células e vasos sangüíneo (Figs. 12c e 12d).

Na borda da ferida óssea via-se a formação de um trabeculado ósseo que se projetava para o centro do defeito caminhando lateralmente ao tecido conjuntivo invaginado. Observou-se a invasão de tecido conjuntivo para 0 centro do defeito preenchido por Capset(Fig 13 a). Em outro defeito preenchido por Capset( Fig. 14 a-d) houve o preenchimento de tecido ósseo com trabéculas finas e esparsas, além de abundante tecido conjuntivo. Não houve neste grupo, formação do calo ósseo nem presença de periósteo e de trabéculas ósseas entremeadas ao tecido mielóide como foi observado no grupo do coágulo e do Surgiplaster.

O exame dos defeitos preenchidos com o sulfato de cálcio da Merck (Fig. 15 a-f) mostrou a formação de tecido conjuntivo fibroso ocupando parcialmente (Figs. 15a e 15e) a área central dos defeitos. Nestes caso, a neoformação óssea a partir da borda invaginava para o interior do canal medular acompanhando as margens desse tecido conjuntivo (Figs. 15a e 15e). Os demais casos apresentaram resultados similares aos dos defeitos tratados com Surgiplaster. 

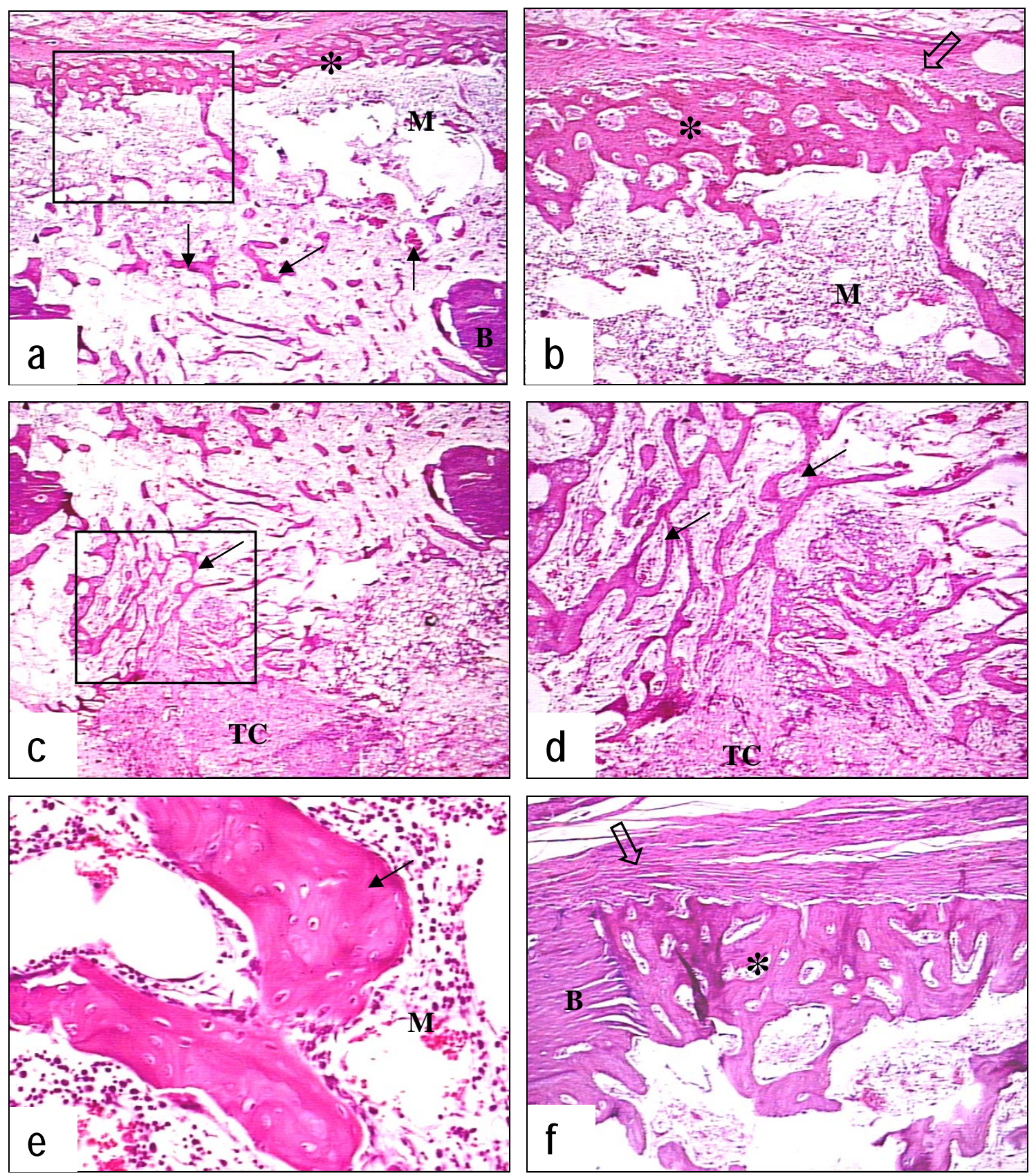

FIGURA 11 - Defeito ósseo preenchido por coágulo sangüíneo, 30 dias pós cirurgia: a) visão panorâmica do defeito exibindo formação de tecido ósseo (asterisco) e mielóide (M) na superfície periostal voltada à derme em forma de calo e pouca formação óssea (setas) na área entre as bordas (B). HE, 15X.; b) Detalhe do calo ósseo da figura anterior (área retangular) exibindo tecido ósseo primário neoformado (asterisco) e tecido mielóide $(\mathrm{M})$ entre a superfície do defeito e o periósteo (seta vazada). HE, 40X; c) visão panorâmica da parte inferior do defeito voltada para o canal medular exibindo formação de tecido ósseo de arranjo trabecular (setas) e, mais internamente de tecido conjuntivo (TC). HE, 25X; d) detalhe da figura anterior (área retangular), com as trabéculas ósseas (setas) e o tecido conjuntivo (TC). HE, 40X; e) maior aumento do osso neoformado (seta) e do tecido mielóide (M). HE, 150X; e f) defeito com fechamento por tecido ósseo primário entrelaçado (arranjo trabecular) (asterisco), de espessura próxima à da borda do defeito (B), já remodelando para tecido ósseo compacto, recoberto pelo periósteo (seta vazada). HE, 40X 

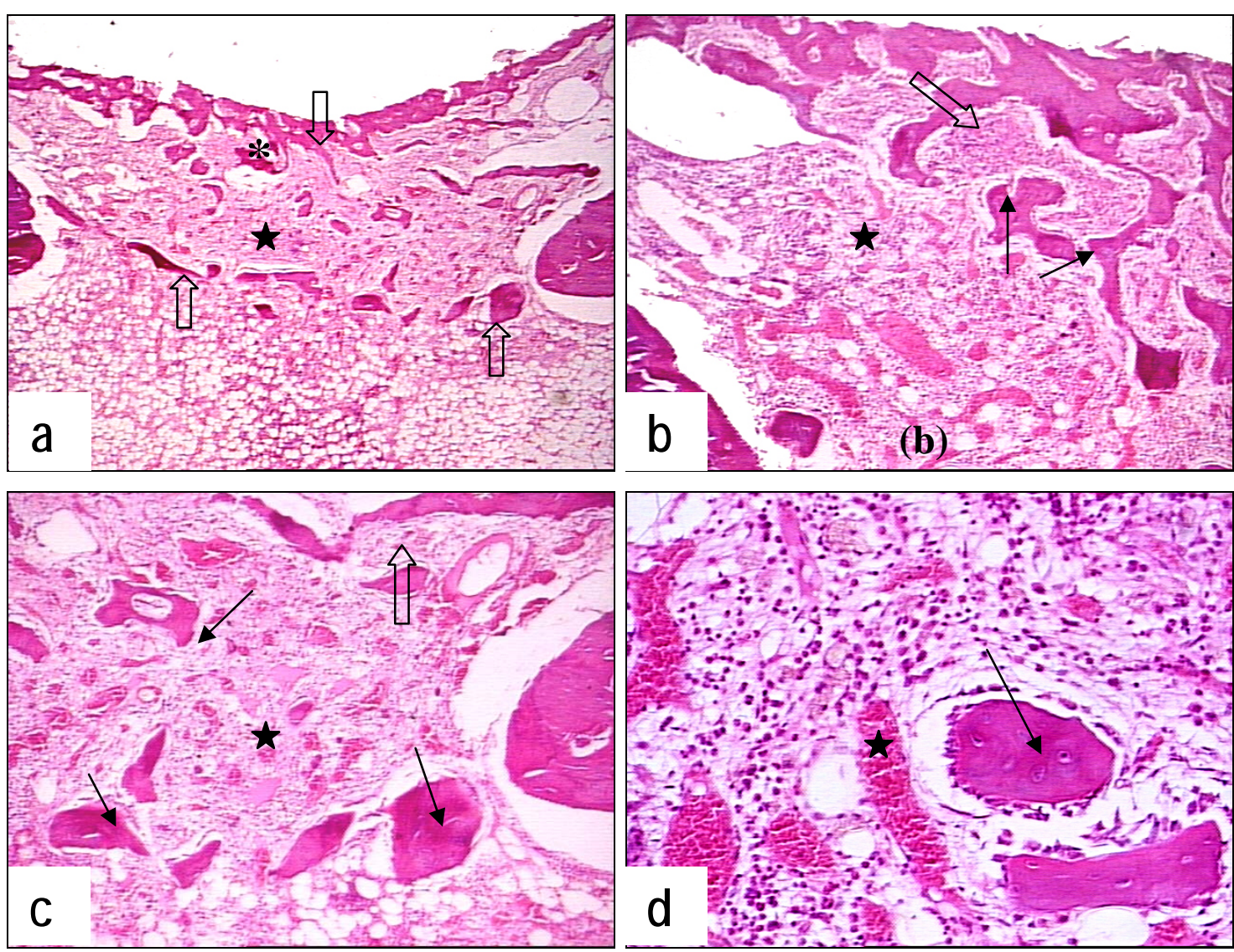

FIGURA 12 - Defeito ósseo preenchido por Surgiplaster, 30 dias pós-cirurgia: a) visão panorâmica exibindo duas finas faixas de tecido ósseo (seta vazada), sendo a externa contínua e a interna fragmentada, e, no espaço entre as duas, presença do tecido conjuntivo sendo substituído por tecido mielóide (estrela). HE, 15X; b-c) detalhes da figura anterior exibindo a borda óssea, as duas faixas de tecido ósseo neoformado (seta vazada), tecido conjuntivo e mielóide (estrela) e traves ósseas (setas). HE, 40X; d) pequenas formações ósseas (setas) envoltas por tecido rico em células e vasos sangüíneos (estrela). HE, 150X 

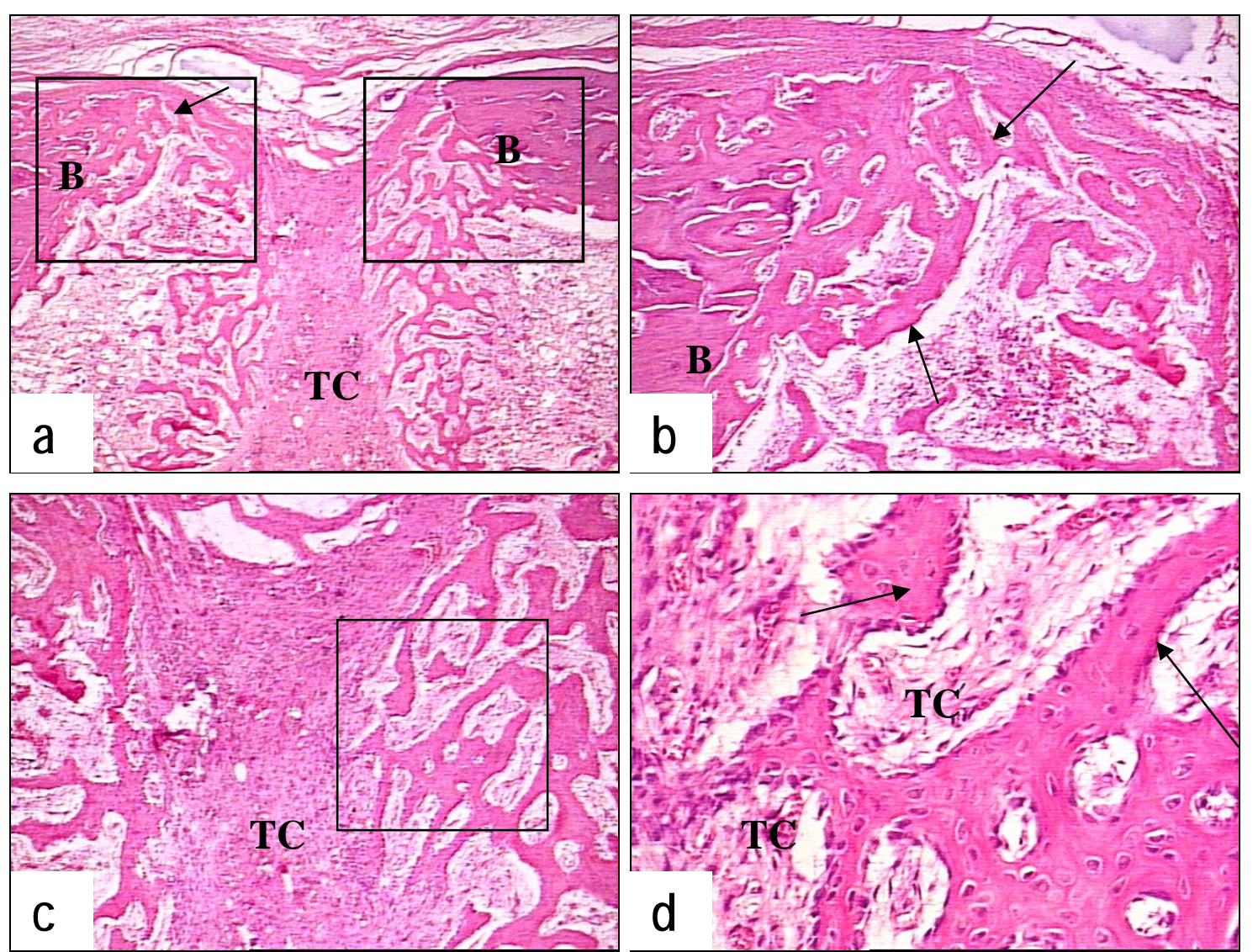

FIGURA 13 - Defeito ósseo preenchido por Capset, 30 dias pós-cirurgia mostrando a região central invadida por tecido conjuntivo: a) visão panorâmica do defeito exibindo formação de osso primário com arranjo (entrelaçado) trabeculado (setas) a partir da borda do defeito (B) em direção ao canal medular e na região central por tecido conjuntivo (TC). HE 15X; b) detalhe da figura anterior (área retangular) do tecido ósseo neoformado (seta) associado à borda óssea (B). HE, 40X; c) região central do defeito, tecido ósseo neoformado (setas) e uma área central perpendicular preenchida por tecido conjuntivo (TC). HE, 40X; e d) detalhe do tecido ósseo neoformado (setas) e do tecido conjuntivo entre as trabéculas.(TC). HE, 150X 

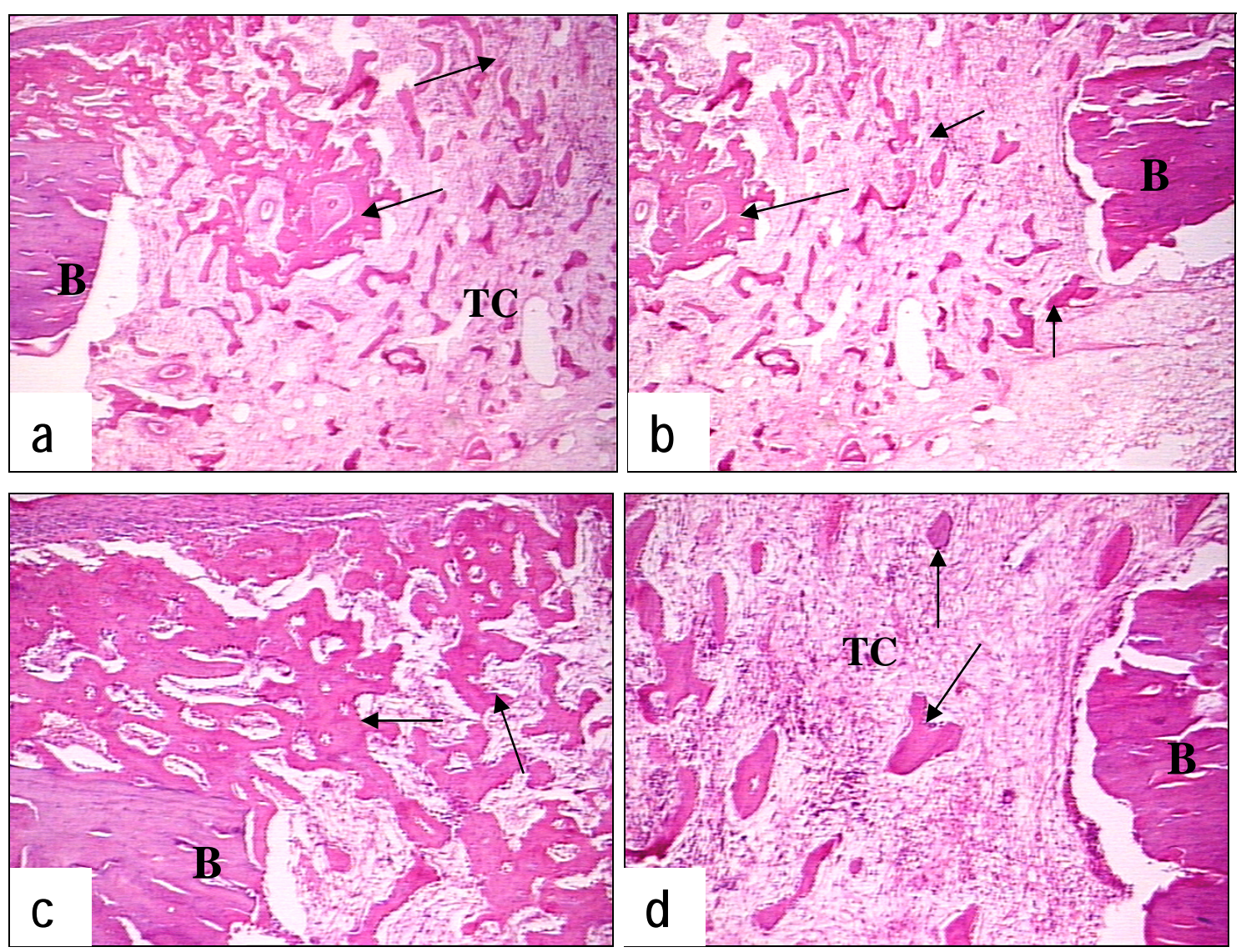

FIGURA 14 - Defeito ósseo preenchido por Capset 30 dias pós-cirurgia: a-b) defeito apresentando preenchimento por tecido ósseo (setas) com trabéculas finas e esparsas, além de abundante tecido conjuntivo (TC) nos espaços inter trabeculares. HE, 15X; $c$-d) detalhe da formação de tecido ósseo (setas), associado ou não à borda óssea (B), e tecido conjuntivo fibroso (TC). HE, 40X 

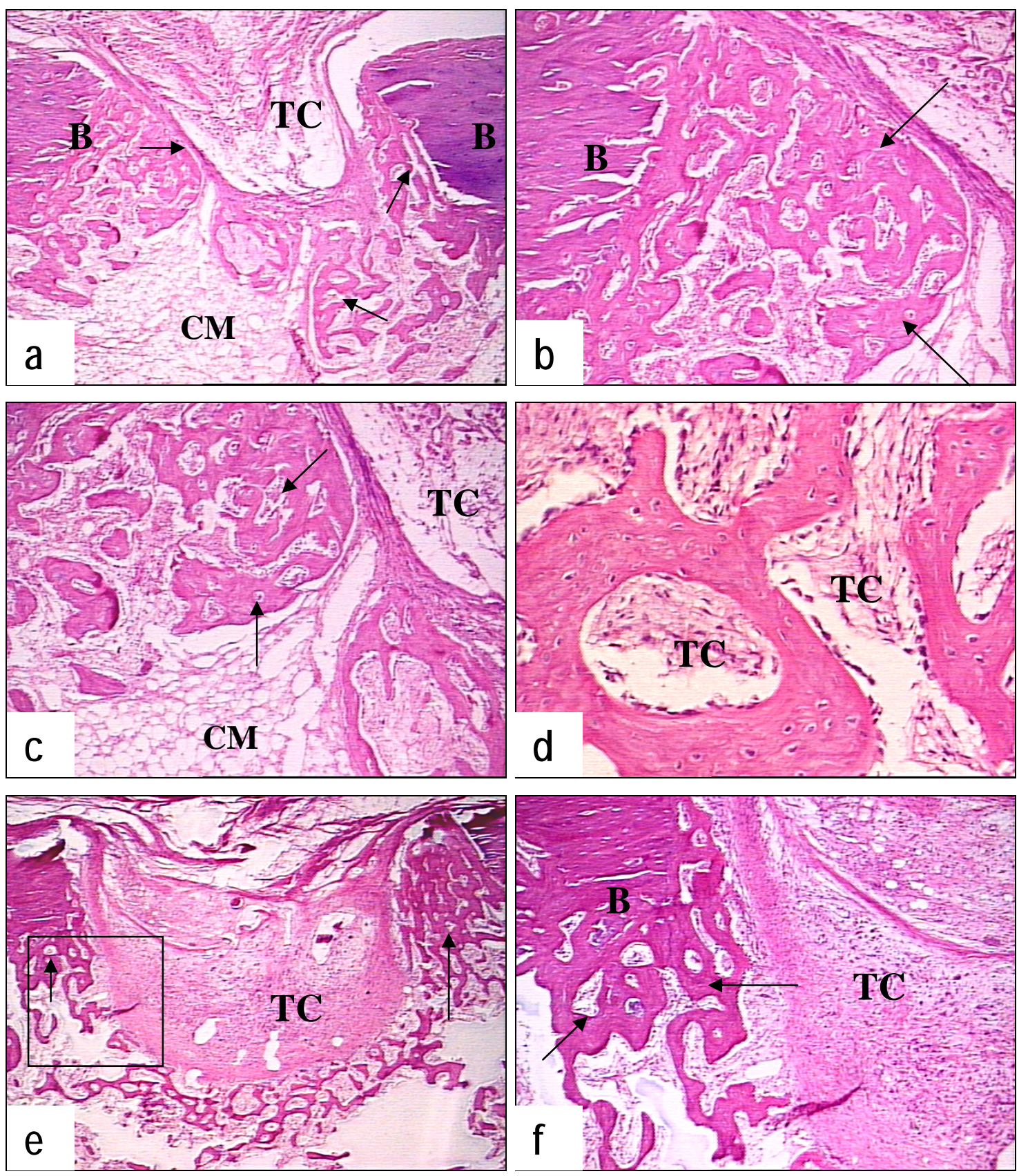

FIGURA 15 - Defeito ósseo preenchido por SC da Merck, 30 dias pós-cirurgia: a) visão panorâmica da formação óssea (seta) a partir da borda do defeito (B) em direção ao canal medular $(\mathrm{CM})$ e, na região central do defeito, de uma depressão resultante da invaginação do tecido conjuntivo fibroso (TC) de recobrimento externo. HE, 15X; b) detalhe da formação óssea (seta) associada à borda do defeito (B). HE, 40X; c) detalhe da formação óssea (seta) e da invaginação do tecido conjuntivo (TC) para o canal medular (CM). HE, 40X; d) aspecto do tecido ósseo neoformado com os espaços entre as trabéculas preenchidos por tecido conjuntivo (TC). HE, 150X; e) visão panorâmica do defeito em que ocorreu o preenchimento por tecido conjuntivo fibroso (TC), que faz saliência para o canal medular com formação de tecido ósseo primário entrelaçado (seta) acompanhando internamente os limites desse tecido. $\mathrm{HE}, 15 \mathrm{X}$; f) detalhe da figura anterior (área retangular) mostrando tecido ósseo neoformado (seta) a partir da borda óssea (B) e tecido conjuntivo fibroso (TC). HE, 40X 
b) Período de 60 dias

Nos defeitos tratados com coágulo sanguíneo ocorreu intensa formação de tecido ósseo a partir da borda com uma espessura maior em relação ao que foi observado nos grupos tratados com sulfato de cálcio. Porém, em todos os casos foi notada uma área central onde o tecido ósseo mostrava-se menos espesso e às vezes interrompido por um feixe de tecido conjuntivo fibroso (Fig. 16).

Os defeitos tratados com o Surgiplaster apresentaram em alguns casos formação a partir da borda óssea formando inúmeras traves ósseas invadindo o canal medular e delimitando espaços ocupados por tecido mielóide. Na região central permaneciam feixes de tecido conjuntivo sendo substituído por tecido ósseo (Fig. 17a-c). Em dois casos, ocorreu pequena formação óssea na borda do defeito e a região central mostrou-se ocupada por tecido mielóide recoberto por tecido conjuntivo fibroso (Fig. 17d).

O quadro histológico dos defeitos tratados com Capset (Fig. 18) e daqueles tratados com sulfato de cálcio da Merck (Fig. 19) foi semelhante, ou seja, em 3 casos houve pequena formação óssea na borda e uma grande abertura central ocupada por tecido conjuntivo (Figs. 18 e 19), e nos outros casos fechamento do defeito por tecido ósseo em remodelação, sendo o tecido de menor espessura que o original em remodelação (Fig. 19d). 

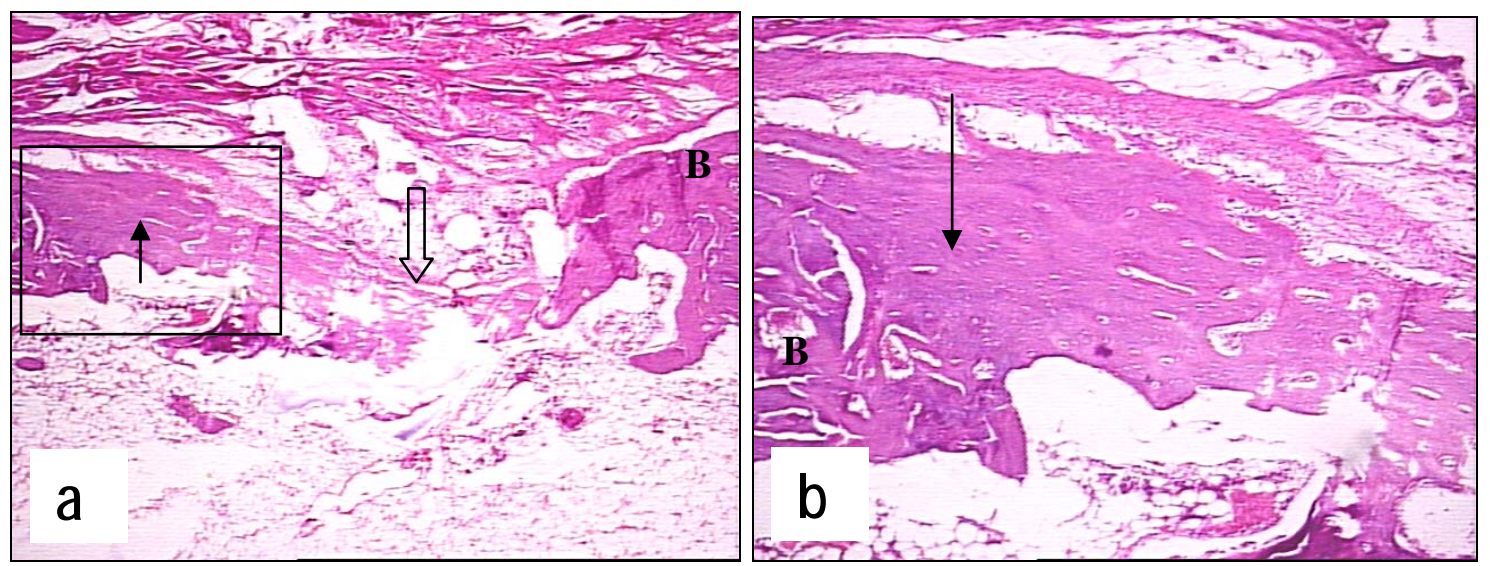

FIGURA 16 - Defeito ósseo preenchido com coágulo sangüíneo, 60 dias pós-cirurgia: a) visão panorâmica do defeito exibindo formação de tecido ósseo (seta) a partir da borda (B) com espessura menor na área central e interrompida por um feixe de tecido conjuntivo fibroso (seta larga); b) detalhe do tecido ósseo neoformado (seta) próximo à borda (B)
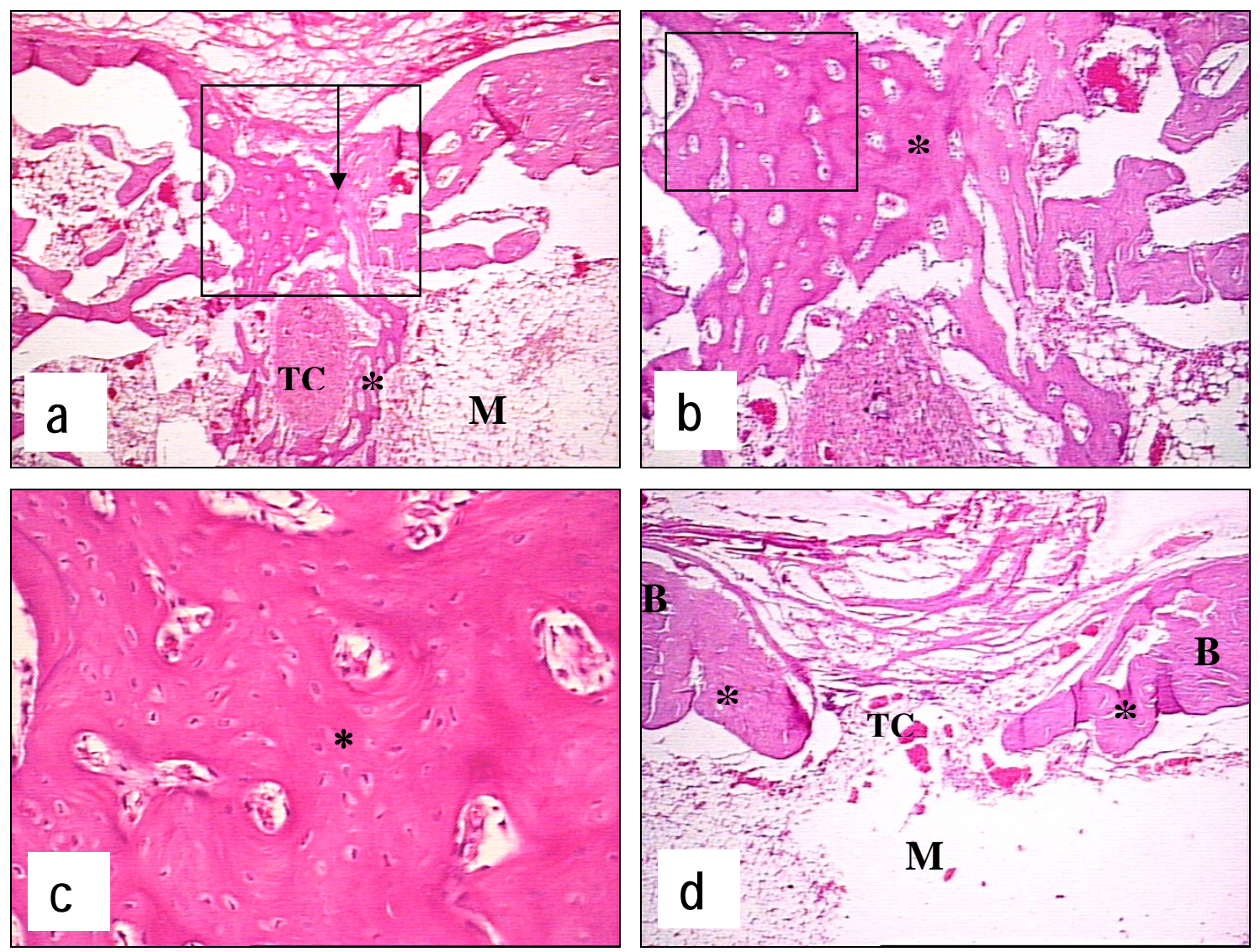

FIGURA 17 - Defeito ósseo preenchido por Surgiplaster, 60 dias pós-cirurgia: a) visão panorâmica mostrando fechamento completo do defeito por tecido ósseo (seta) de menor espessura com uma pequena depressão na área central ocupada por uma massa de tecido ósseo trabeculado (asterisco); na região central do canal medular (M) pode-se observar uma área de tecido fibroso (TC). HE, 15X; b e c) Detalhe da região de união do tecido ósseo neoformado (asterisco) em decorrência do seu crescimento pelas bordas do defeito. HE, 150X; d) defeito em que o crescimento ósseo (asterisco) ficou restrito à borda do defeito (B) sendo a região central ocupada pelo tecido fibroso (TC) e tecido mielóide (M). HE, 15X 


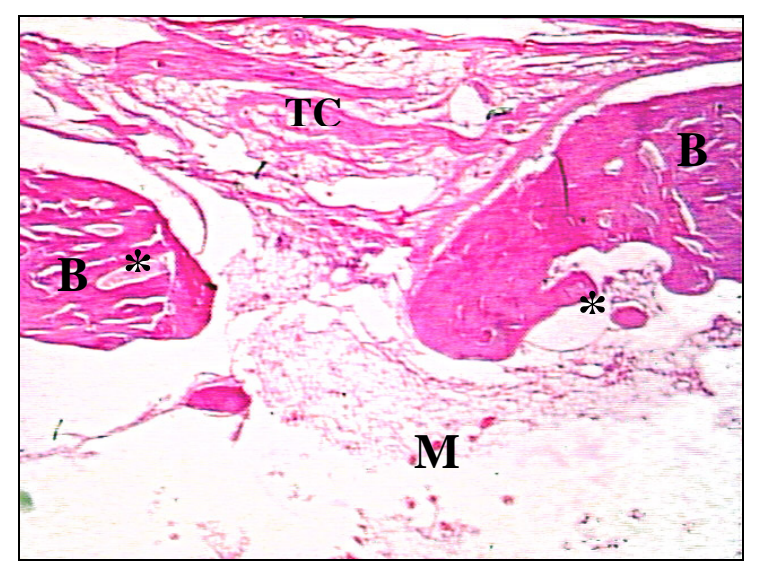

FIGURA 18 - Defeito ósseo preenchido por Capset, 60 dias pós-cirurgia. Visão panorâmica que mostra o crescimento ósseo (asterisco) restrito à borda do defeito $(B)$ sendo a região central invadida pelo tecido fibroso (TC) e tecido mielóide (M). HE,15X
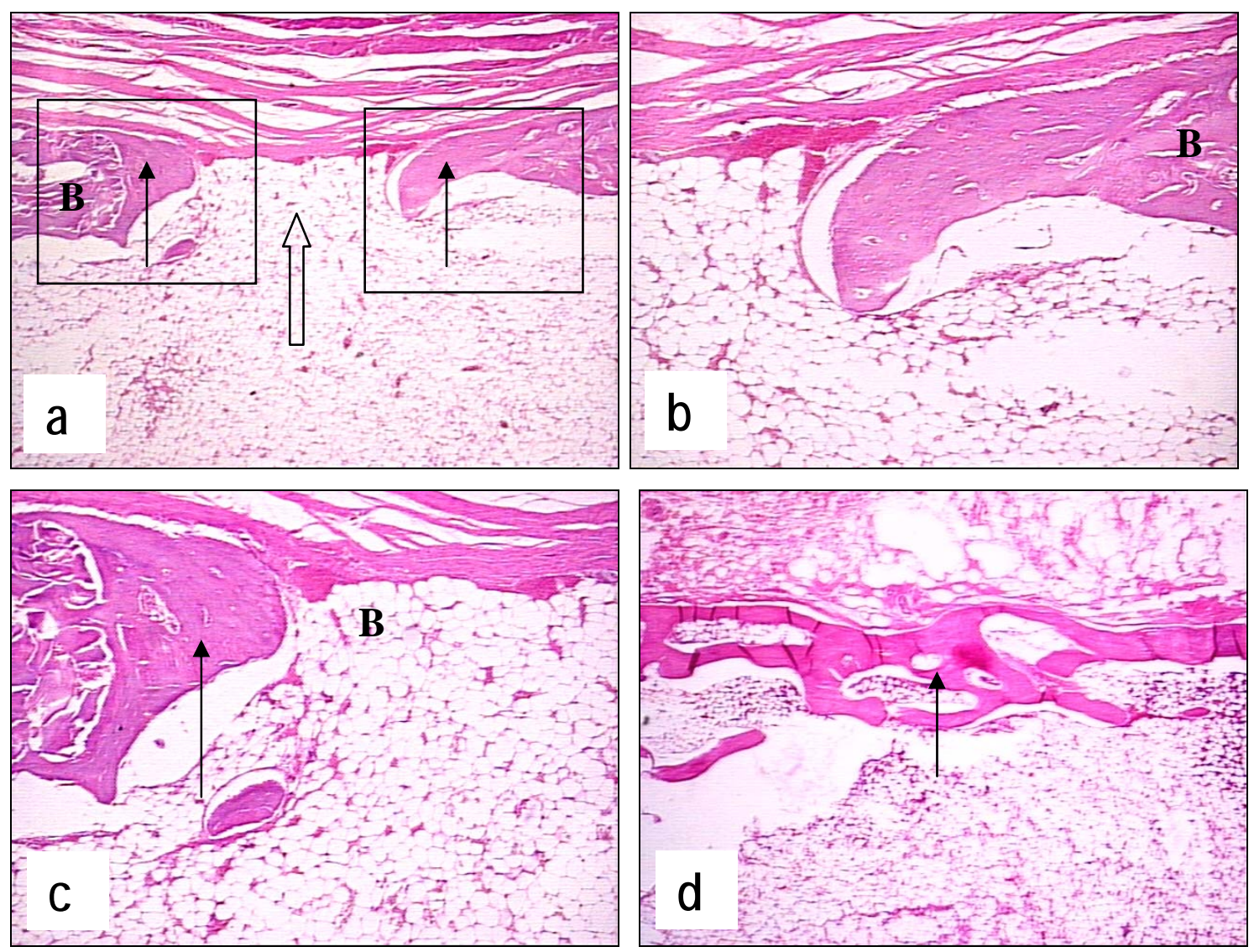

FIGURA 19 - Defeito ósseo preenchido por sulfato de cálcio da Merck, 60 dias pós-cirurgia: a) visão panorâmica do defeito exibindo pequena formação de tecido ósseo (seta) a partir da borda (B) com uma grande falha óssea (seta larga) na região central recoberta por tecido conjuntivo fibroso. HE, 15X; b e c) maior aumento das áreas assinaladas, mostrando as bordas ósseas (B). HE, 40X; d) caso em que houve completo fechamento do defeito por tecido ósseo trabeculado (seta) de menor espessura que o original. HE, 15X 
c) Período de 90 e 180 dias

Em ambos os períodos o quadro histológico mostrou-se semelhante. Nos defeitos tratados com coágulo sangüíneo (Fig. 20) ocorreu completo fechamento da área do defeito por tecido ósseo de arranjo compacto, de menor espessura que a cortical original, com uma pequena depressão central. Nos grupos tratados com Surgiplaster (Fig. 21), sulfato de cálcio da Merck (Fig. 22) e, Capset (Fig. 23), todos os defeitos mostraram-se preenchidos por duas corticais ósseas compactas de menor espessura que a da borda do defeito com uma região central ocupada por tecido mielóide.

Na figura 24 tem-se a espessura da cortical óssea padrão, para efeito de comparação.

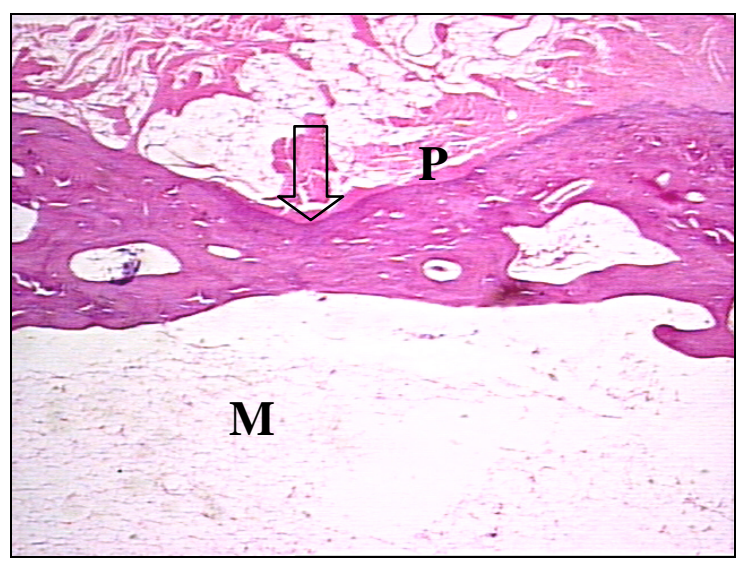

FIGURA 20 - Defeito ósseo preenchido com coágulo, 180 dias pós-cirurgia, mostrando fechamento completo por tecido ósseo de arranjo compacto, com uma pequena depressão na região central (seta larga) sem a ocorrência de comunicação entre o canal medular (M) e o periósteo $(\mathrm{P}) . \mathrm{HE}, 15 \mathrm{X}$ 


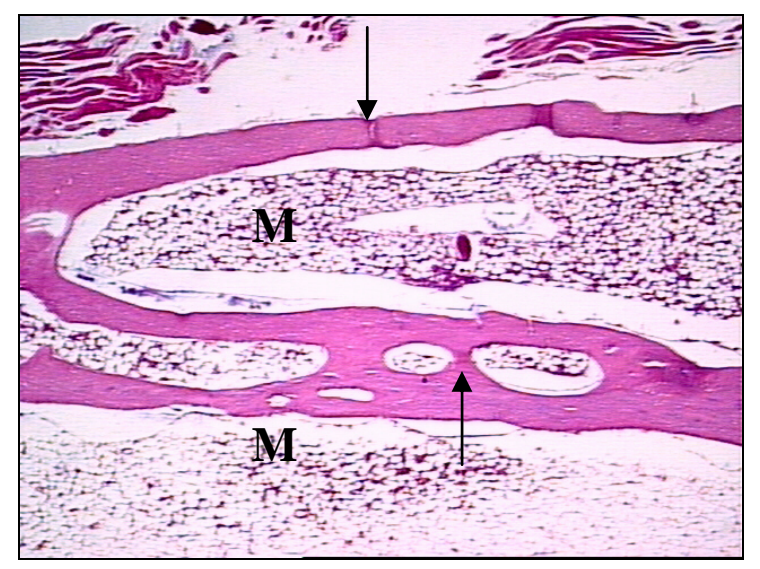

FIGURA 21 - Defeito ósseo preenchido com Surgiplaster, 180 dias, exibindo a formação de duas corticais ósseas (setas) de menor espessura a partir da borda do defeito, com uma região central ocupada por tecido mielóide (M). HE, 15X

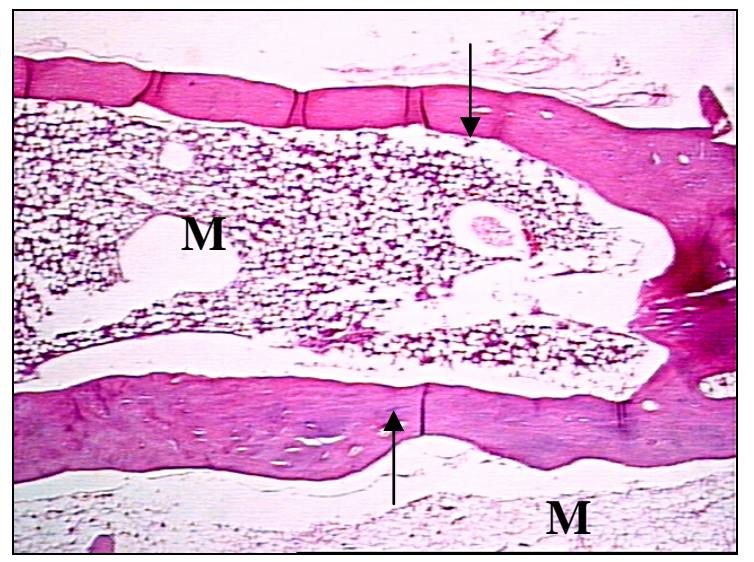

FIGURA 22 - Defeito ósseo preenchido com o sulfato de cálcio da Merck, 180 dias, exibindo a formação de duas corticais ósseas (setas) de menor espessura a partir do borda do defeito, com uma região central ocupada por tecido mielóide (M). HE, 15X 

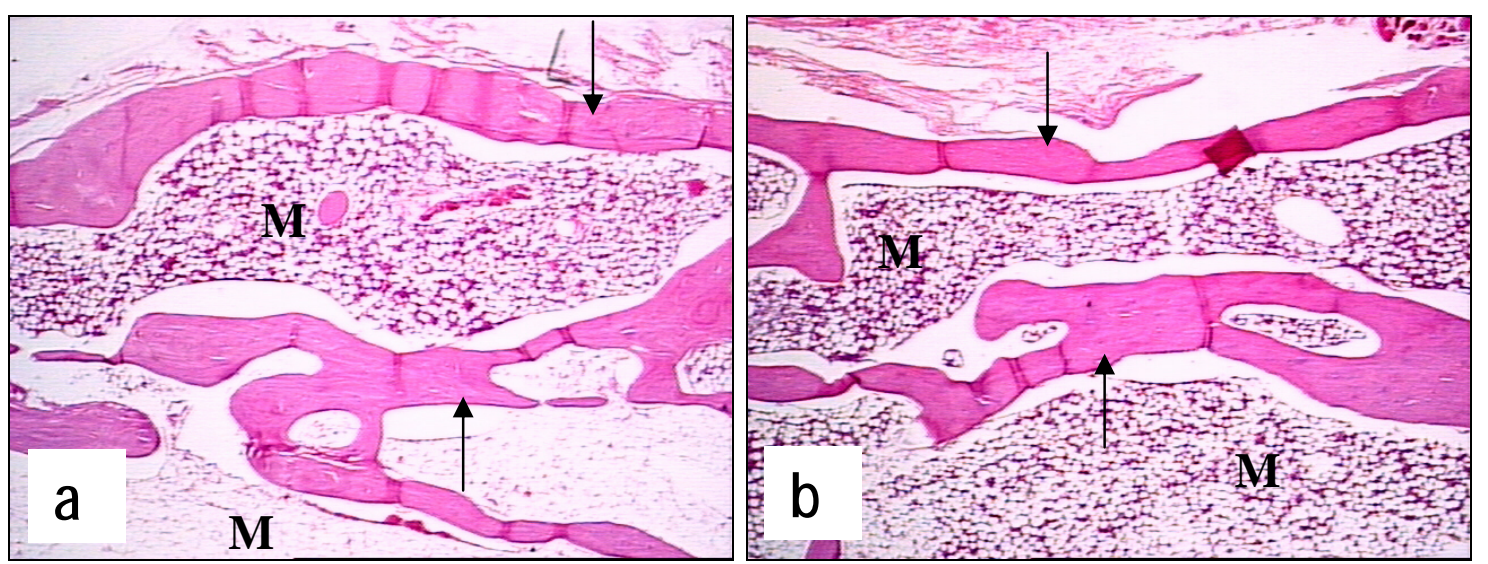

FIGURA 23 - Defeito ósseo preenchido com Capset, 180 dias. Dois casos (a e b) mostram a formação de duas corticais ósseas (setas) de menor espessura com uma região central ocupada por tecido mielóide (M). HE, 15X

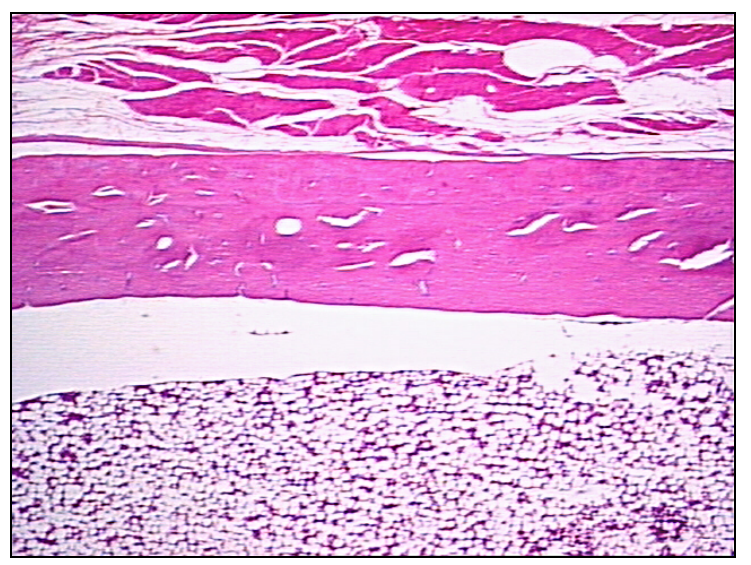

FIGURA 24 - Cortical óssea padrão da região utilizada para a confecção do defeito.HE, 15X 
6

Discussão 


\section{DISCUSSÃO}

\subsection{Da Metodologia}

Para análise experimental do reparo dos defeitos ósseos a maioria das pesquisas tem utilizado como modelos experimentais ratos, coelhos, cães e ovelhas. WALSH et al. $^{115}$, em 2003, utilizou fêmur de carneiro, CALHOUN et al. ${ }^{16}$, em 1967, mandíbula de cães, MURASHIMA et al. ${ }^{71}$, em 2002, mandíbula de cães Beagle, HANKER et al. ${ }^{42}$, em 1984, mandíbula de coelho e macaco, AL RUHAIMI ${ }^{3}$, em 2001, mandíbula de coelho, NAJJAR et al. $^{72}$, em 1991, mandíbula e tíbia de coelho, AL RUHAIMI ${ }^{1}$, em 2001, palato de coelho. CLOKIE et al. ${ }^{20}$, em 2002. Entretanto cada modelo experimental tem suas peculiaridades quando comparado ao processo de reparo ósseo em humanos. Espécies inferiores, como o rato, oferecem um alto potencial para osteogênese, tornando os resultados obtidos não confiáveis e inadequados para serem transferidos para os humanos.

O estudo do reparo ósseo, neste trabalho, recaiu sobre os coelhos, da raça New Zealand, pelo fato de que a grande maioria dos pesquisadores 0 elegeu esse animal para experimento. Do mesmo modo, a maioria opta por utilizar, o Sulfato de Cálcio associado a outros biomateriais ou isoladamente, em diferentes locais com diversos tamanhos e profundidades. (FRAME ${ }^{35}$, 1980; HANKER et al. ${ }^{43}$, 1984; NAJJAR et al. ${ }^{72}$, 1991; MACNEIL et al. ${ }^{60}$, 1999). O coelho permite uma maior padronização quanto a raça, idade, sexo e peso, além de ser mais dócil, o que permite maior facilidade de 
manutenção em cativeiro e melhor controle do seu estado de saúde. O fêmur tem sido considerado um sítio experimental adequado para p estudo de diversos biomaterais, inclusive por permitir uma padronização e ser fácil a obtenção das amostras. Foram utilizados os fêmures de ambos os lados virtude da sua espessura e de sua capacidade de receber o implante do material sem, contudo, incapacitar o animal. (CONCANNON et al. ${ }^{22}, 1997$ )

Os ossos longos são subdivididos em regiões: epífises, metáfises e diáfises. Epífise e metáfise são caracterizadas por uma camada cortical compacta que circunda o corpo de um osso esponjoso constituído por trabéculas, na forma de bastonetes ou placas. Nas diáfises, o osso cortical torna-se mais finos e as trabéculas são substituídas por uma cavidade medular coesiva (MARX; GARG ${ }^{63}, 1998$ )

Em ossos curtos (vértebras, carpo e tarso) não há diáfise, e as metáfises estão unidas. As costelas e a mandíbula são constituídas de osso esponjoso circundado por uma camada cortical. A estrutura mineralizada do osso é revestida de periósteo e de endósteo. Os canais vasculares no interior do osso compacto são continuações dos envoltórios de periósteo ou endósteo (envoltório harvesiano).Tanto o periósteo como o endósteo têm potencial osteogênico e vascularização abundante, o que permite a participação nas atividades modeladoras e remodeladoras, como também no reparo ósseo. O periósteo envolve a superfície externa dos ossos, com exceção das superfícies articulares, tendões e inserções ligamentares. Sua estrutura varia desde delicada lâmina de tecido conjuntivo frouxo até membranas fibrosas densas. As células osteoprogenitoras estão localizadas em geral nas vizinhanças dos vasos sangüíneos perto da superfície óssea. As células do endósteo pertencem ao estroma da medula óssea ou são derivadas de osteoblastos latentes, os quais também constituem a fonte principal das células basais nos canais corticais (JUNQUEIRA ; CARNEIRO ${ }^{47}$,1999). 
O tecido ósseo está composto por $65 \%$ de mineral (principalmente hidroxiapatita), $25 \%$ de matriz orgânica e $10 \%$ de água. O colágeno representa $90 \%$ da fase orgânica e os $10 \%$ restantes consistem de proteoglicanos de pequeno peso molecular e proteínas não-colágenas. Entre estas, é notável a osteocalcina, já que é específica para osso. Ela é sintetizada por osteoblastos. A osteopontina é outro componente relacionado com os osteclastos. A osteonectina, uma glicoproteína fosforilada, serve para unir a apatita ao colágeno (JUNQUEIRA ; CARNEIRO ${ }^{4}$, 1999).

No nosso trabalho foram feitas duas cavidades no tamanho de $5 \mathrm{~mm}$ de diâmetro por $8 \mathrm{~mm}$ de profundidade, realizados com broca trefina montada em motor elétrico (AL RUHAIMI ${ }^{2}, 2000$, CARNEIRO $^{18}$, 2003), uma delas próxima da epífise e a outra mais distalmente. Ë oportuno salientar que houve um caso de fratura do fêmur, pelo fato de o animal, ainda sob o efeito da anestesia, ter sido colocado de volta na gaiola para o descanso, movimentando-se muito e provocando a fratura. Esse acidente de percurso foi controlado nos experimentos posteriores, com a adoção de um tempo maior de descanso após o término do efeito da anestesia, num local diferente da gaiola, com uma superfície plana e macia. Somente depois desse período animal era recolocado na sua gaiola para alimentação e hidratação.

Para o preparo das cavidades cirúrgicas foi utilizada a trefina, que permite um procedimento menos traumático e cavidades cirúrgicas com bastante padronização. A trefina possui linhas demarcatórias que facilitam o estabelecimento do limite de penetração no fêmur do coelho (LEME et al. ${ }^{57}$, 2004), obtendo-se assim uma profundidade e calibre padronizados para todos os materiais.

Não existem na literatura específica trabalhos sobre o tamanho crítico das cavidades. Porém, quando no estudo piloto, nas cavidades preparadas com brocas esféricas em tíbias de coelhos de diâmetro e profundidade 
aproximados de $3 \mathrm{~mm}$, não foi possível diferenciar a osteogênese, pois houve um crescimento igual para todos os materiais implantados.

Segundo MACNEILL ${ }^{60}$, o tempo necessário para ocorrer a remodelação óssea é em média seis semanas (42 dias). Desse modo, foi proposto um período experimental de um, dois, três e seis meses com o objetivo de verificar uma reação do tecido ósseo a curto, médio e longo prazo, após o preenchimento dos defeitos com o sulfato de cálcio, e do coágulo, no grupo controle.

O tempo de observação é muito variável entre os autores. Assim TURNER et al. ${ }^{110}$, em 2001, trabalhando em úmero de cão realizou suas observações em 2, 6 e 13 semanas e constatou que o SC foi reabsorvido completamente em 13 semanas; WALSH et al. ${ }^{115}$, em 2003, trabalhando em fêmures de carneiro, optou por 12 semanas; MURASHIMA et al. ${ }^{71}$ em 2003, utilizando mandíbula de cão Beagle, optou por 8 e 16 semanas; JAMALI ${ }^{44}$, em 2002, fez experimentos com tíbia de coelho por 6 semanas e constatou que o SC foi reabsorvido em 42 dias e finalmente AL RUHAIMI ${ }^{2}$, em 2000, trabalhando no côndilo de fêmur de coelho, optou por 8 semanas.

A grande variabilidade no tempo do experimento em animais dificulta em parte uma análise comparativa com os dados do nosso trabalho. $O$ mesmo ocorre nas observações realizadas em pacientes: MARZOLA et al. ${ }^{64}$, em 1991, 24 meses; SETYA ; BISSADA ${ }^{99}$, em 1999, fizeram suas observações em 12 meses; DE LEONARDIS ; PECORA ${ }^{29}$, em 2000, em 9 meses; KELLY ${ }^{49}$, em 2001, em 6 e 12 meses; MARAGOS et al. ${ }^{61}$, em 2002, 12 meses.

A administração da medicação sistêmica de antiinflamatório por meio de injeção intramuscular de Banamine (Flonexin Meglumine) por 4 dias após a cirurgia teve a finalidade de minimizar a dor. O antibiótico, Flotril, foi 
utilizado para evitar uma possível infecção pós-operatória.(KANIA et al. ${ }^{48}$, 1998). Ambos os fatores, dor e infecção, poderiam interferir nos resultados.

Foi realizado a ortotanásia dos animais nos períodos experimentais por meio de uma dose letal intravenosa de barbitúricos diluídos em solução salina (injeção intraperitonial letal de tiopental sódico (Abbot), numa dosagem de $200 \mathrm{mg} / \mathrm{kg}$ ).

O processamento histológico empregado foi o convencional e utilizado pela grande maioria dos autores, em que a coloração HE permite evidenciar células do tecido conjuntivo e também do tecido ósseo.

Para a obtenção e análise das imagens foi usado um sistema de captura de imagens composto por microscópio Axioskop (Zeiss) acoplado a uma câmera Sony CCD - IRIS/RGB, no qual as imagens eram congeladas e gravadas por meio de um soft KS 300 Zeiss, o que facilitou a análise dos eventos histopatológicos.

\subsection{Dos Resultados}

Há mais de cinco décadas as pesquisas tem mostrado que o sulfato de cálcio hemi-hidratado, também chamado de gesso Paris, é seguro e efetivo para uma variedade de aplicações clínicas tanto na Medicina, principalmente na Ortopedia, como na Odontologia, em que já é amplamente usado em procedimentos para preservação da crista alveolar após exodontias, reparo de defeitos periodontais, como barreira biológica em cirurgias parendodônticas e auxiliar na Implantodontia. (CONNER ${ }^{23}$, 1996; PECORA et al. ${ }^{81}$, 1997; ALHADAINY et al. ${ }^{1}$, 1998; DE LEONARDIS ; PECORA $^{28}, 1999$; GOLDMAN et al. ${ }^{38}$, 2000; COURI et al. ${ }^{24}, 2002$; CHOGLE ; MICKEL ${ }^{19}$, 2003). 
O sulfato de cálcio como material preenchedor de tecido ósseo vem sendo utilizado em vários sítios do esqueleto ósseo:a) humanos: mandíbula (SHAFFER ; APP ${ }^{100}$, 1971; COETZEE ${ }^{21}$, 1980; MCKEE ; BAILEY ${ }^{66}$, 1984; DE LEONARDIS ; PECORA ${ }^{28}$, 1999; DE LEONARDIS ; PECORA ${ }^{29}$, 2000; AL RUHAIMI ${ }^{2}$, 2000; KIM et al. $^{52}$, 1998; PECORA ${ }^{82}$, 1998), radio distal $\left(\right.$ PELTIER $^{87}$, 1961), ossos longos ( BLAHA $^{14}$, 1998; KELLY et al. ${ }^{49}$, 2001; PELTIER ${ }^{86}$, 1959; TURNER et al. ${ }^{110}$, 1999), e lesões ósseas benignas (GITELIS et al. $^{37}$, 2001). b) animais: crânio e face (FRAME ${ }^{35}$, 1980; SNYDERS et $\mathrm{al}^{101}, 1993$ ), ossos longos ( TURNER et al. ${ }^{110}$, 1999), fusão espinal(HADJIPAVLOU et al. ${ }^{41}$, 2000) defeito osteocondral (NIEDERAUER et al. $\left.^{74}, 2000\right)$

Além disso, o sulfato de cálcio também tem sido usado como barreira biológica na regeneração tecidual guiada, impedindo fisicamente a proliferação das células do tecido conjuntivo e epitelial para dentro do defeito ósseo permitindo a regeneração óssea, pelo princípio da osteopromoção (SOTTOSANTI $^{102,104}$, 1993, 1997; ANSON $^{6}$, 1996; PECORA, et al. ${ }^{81}$, 1997; JANTARAT et al. ${ }^{45}$, 1999).

O sulfato de cálcio também é empregado como veículo para aplicação de antiinflamatório (MARZOLA et al. ${ }^{64}, 1991$ ), de antibióticos (DAHNERS ; FUNDERBURK $^{26}$, 1987; MOUSSET et al. ${ }^{70}$, 1995; BENOIT et al. ${ }^{13}$, 1997; SETYA ; BISSADA ${ }^{99}$, 1999; CANO et al. ${ }^{17}$, 1999); associado com osso xenógeno mais antibiótico (ROSEN ; REYNOLDS ${ }^{94}$, 1999) ou associado a fatores de crescimento (ROSEMBLUM et al. ${ }^{95}$, 1993; WALSH et al. ${ }^{115}, 2003$ ), a proteína óssea morfogenética (YAMASAKI et al. ${ }^{113}$, 1988; BAl et al. ${ }^{10}$ ,1996; WALSH et al. $\left.{ }^{115}, 2003\right)$, a anti-sépticos (COETZEE $\left.{ }^{21}, 1980\right)$, a plasma rico em plaquetas (KIM et al. ${ }^{53}, 2002$ ), e ainda a outros biomateriais como a hidroxiapatita (LEWIS et al. ${ }^{58}$, 1989; DAMIEN ${ }^{27}$, 1990; SATO et al. ${ }^{97}, 1998$; RAFTER et al. $\left.{ }^{93}, 2002\right)$, vidro bioativo $\left(M E L O^{68}, 2003\right)$, carbonato de cálcio (JAMALI et al. $^{44}$, 2002), DFBDA (osso bovino seco, congelado e 
desmineralizado) (MAZE et al. $\left.{ }^{65}, 1994\right)$, partículas de dentina (SU-GWAN et al. $^{108}$, 2001; KIM et al. ${ }^{50}$, 2001) e osso autógeno (ORSINI $\left.{ }^{77}, 2001\right)$.

Salientamos que o sulfato de cálcio não é osteoindutor, ou seja, não induz a osteogênese em sítios heterotópicos como tecido muscular ou o subcutâneo e não parece acelerar a formação óssea em sítios ortópicos. Entretanto, atua como uma matriz física favorecendo a deposição de novo osso em sua superfície. Parece ter as propriedades de guiar o crescimento ósseo em área onde isso não ocorreria de forma completa, ou seja, atuaria como um material osteocondutor (HADJIPAVLOU et al. ${ }^{41}, 2000 ; \mathrm{AL}$ RUHAIMI $^{2}, 2000$; PINTO SIBONI $\left.{ }^{91}, 2001\right)$

No nosso estudo foi possível detectar em que momento o material passava a ser reabsorvido. No período inicial era de 30 dias, já se notava, principalmente no grupo do sulfato de cálcio da Merck e Capset, uma invaginação do tecido conjuntivo para o interior do defeito.

No presente trabalho foi possível observar que os defeitos ósseos, tratados de modo geral, mostraram ocorrência de neoformação óssea em todos os grupos estudados, sendo indiferente a marca comercial do produto utilizado.

Assim o Surgiplaster, promoveu com 30 dias, a formação de finas trabéculas ósseas preenchidas por uma massa de tecido conjuntivo frouxo sendo substituído por tecido mielóide (Fig.12a,b,c). Esse material apresentou um quadro histológico próximo ao observado no grupo controle.

Já os defeitos tratados com o sulfato de cálcio da Merck e o Capset , em 3 e 2 casos, respectivamente, mostraram a formação de tecido conjuntivo fibroso ocupando total ou parcialmente a área central do defeito. Nesses casos, a neoformação óssea a partir da borda invaginava para o interior do canal medular acompanhando as margens desse tecido 
conjuntivo (Figs. 15a e 13a). Os demais casos desses dois tratamentos apresentaram resultados similares aos observados nos defeitos tratados com Surgiplaster.

$\mathrm{BAHN}^{9}$, em 1966, avaliou clínica e histologicamente, defeitos bilaterais criados na mandíbula de 10 coelhos, preenchendo o lado direito com uma mistura de SC mais fluída e o lado esquerdo com coágulo. Aos 4 dias observou maior reparo ósseo no grupo controle (coágulo). Porém, aos 22 dias o defeito no grupo experimental estava preenchido com tecido ósseo neoformado, enquanto no grupo controle só havia evidência da existência de fibroblastos e de atividade osteóide. Já no nosso trabalho observamos aos 60 dias um trabeculado mais espesso e mais extenso no grupo experimental tratado com o sulfato de cálcio do que no controle.

O estudo de VICTOR et al. ${ }^{112}$, em 1975, utilizando SC em alvéolos de ratos, após a exodontia, mostrou aos 30 dias que o SC era reabsorvido e bem tolerado pelo organismo, mas havia retardado a cronologia do processo de reparo por perturbar a organização do coágulo, na comparação do grupo experimental com o grupo controle, preenchido somente com coágulo.

Os estudos de PARSONS et al. ${ }^{79}$, 1988, mostraram que , o SC em duas semanas foi bastante reabsorvido, e em 4 semanas o crescimento trabecular estava completamente infiltrado no local do implante e não havia remanescente de SC.

Esse fato também foi constatado nesta pesquisa, pois, nos nossos espécimes de 30 dias não foi mais possível detectar mais a presença de sulfato de cálcio na área do defeito. É possível que uma maior velocidade de reabsorção do material tenha contribuído para a formação de tecido conjuntivo fibroso para o interior do defeito nos casos preenchidos com o sulfato de cálcio da Merck e o Capset. Como o nosso período inicial foi de 30 
dias, não foi possível saber quando isso ocorreu e se havia alguma diferença entre materiais.

Por outro lado, SATO et al. ${ }^{97}$, em 1998, em estudo histológico em defeitos ósseos em tíbias de coelhos, tratados com sulfato de cálcio hemihidratado e Hidroxiapatita, observou que o uso isolado do SC não havia promovido nenhuma formação óssea após 30 dias.

Os defeitos ósseos preenchidos por Surgiplaster, apresentaram após 60 dias, em alguns casos, formação de tecido ósseo desorganizado a partir da borda óssea com inúmeras traves ósseas que invadiam o canal medular e cujos espaços intertrabeculares estavam ocupados por tecido mielóide, havendo ainda na região central do defeito um feixe de tecido conjuntivo sendo substituído por tecido ósseo (fig.17a,b,c). Em dois casos, ocorreu pequena formação óssea na borda do defeito, estando a região central deste ocupada por tecido mielóide recoberto por tecido conjuntivo fibroso (Fig. 17d).

Já os defeitos ósseos preenchidos por SC da Merck e Capset, em 3 casos cada um, apresentaram pequena formação óssea na borda e uma grande porção central ocupada pelo tecido conjuntivo. Nos outros casos, ocorreu fechamento do defeito por tecido ósseo de menor espessura que o original, com a presença de tecido conjuntivo fibroso ocupando total ou parcialmente a área central do defeito. Nesses casos, a neoformação óssea a partir da borda do defeito invaginava para o interior do canal medular acompanhando as margens do tecido conjuntivo. Os demais casos de ambos os tratamentos apresentaram resultados similares aos observados nos defeitos tratados com Surgiplaster ou seja, formação de tecido ósseo desorganizado com inúmeras traves ósseas invadindo o canal medular.

Estudo realizado por AL RUHAIMI ${ }^{2}$ (2000) utilizando o Capset isoladamente ou associado a outros materiais de enxerto (Ostegraf, BOP) no 
tratamento de defeitos assinala que, após 8 semanas, o Capset apresentava um quadro semelhante ao da nossa pesquisa,. Entretanto, a sua associação com outros biomateriais havia potencializado o processo da osteogênese. Assim segundo o autor, não é recomendado o uso isolado do SC como preenchedor de defeito ósseo, sendo indicada a sua utilização sempre associado a outros biomateriais.

Nos dois períodos mais tardios de 90 e 180 dias, os quadros histológicos mostraram semelhantes entre si. Assim, nos grupos tratados com sulfato de cálcio, todos os defeitos mostraram-se preenchidos no local da cortical original por duas corticais ósseas compactas paralelas, ambas de menor espessura do que a da borda do defeito, delimitando com uma região central ocupada por tecido mielóide.

MURASHIMA et al. ${ }^{71}$, em 2002, utilizando Surgiplaster em defeitos ósseos preparados em mandíbulas de cães Beagles após apicetomia, não observaram em nenhum espécime a presença de Surgiplaster decorridas 8 e 16 semanas após as cirurgias. Novo osso havia preenchido o defeito de ambos os lados, tanto no grupo experimental como no controle, após 16 semanas.

Nos estudos de APAYDIN ; TORABINEJAD ${ }^{8}$, em 2002, utilizando o Capset, em cirurgia parendodôntica em cães,notaram histologicamente, após 4 meses, evidências de deposição de cemento adjacente ao material retrobturado e de regeneração nos locais da osteotomia. O cemento cicatricial formado foi de $49,94 \mathrm{~mm}^{2}$ sem o SC e de $40,71 \mathrm{~mm}^{2}$ com SC, sem diferença estatística significante entre ambos os grupos experimentais.

BEESON ${ }^{11}$, em 1981, avaliando histológica e radiograficamente, o implante de SC hemi-hidratado misturado com água estéril no seio frontal de 6 cães, observou após 4 e 6 meses, a ocorrência de regeneração óssea 
completa, concluindo que o SC na presença de osso e periósteo parece estimular a osteogênese.

DE LEONARDIS ; PECORA ${ }^{28}$, em 1999, avaliaram clínica e histologicamente os resultados do aumento do seio maxilar com emprego de Surgiplaster como material de enxerto, em 12 pacientes (15 seios maxilares), aos 6 , 9 e 12 meses após as cirurgias. Os resultados mostraram um novo tecido ósseo dentro do seio maxilar, indicando que o SC pode ser um material aceitável para a elevação do seu assoalho.

A análise dos cortes histológicos do grupo controle preenchido somente com coágulo sangüíneo mostrou que o processo de reparo foi melhor aqui do que em qualquer dos grupos experimentais, em qualquer dos períodos de avaliação. Assim, aos 30 dias, observou-se a formação de tecido ósseo primário entrelaçado e mielóide na superfície periostal, enquanto na região voltada para o canal medular ocorreu formação de finas trabéculas ósseas associadas a uma massa de tecido conjuntivo localizado próximo à borda do defeito. Aos 60 dias, os defeitos apresentavam uma intensa formação de tecido ósseo a partir da borda exibindo maior espessura em relação aos grupos tratados com o sulfato de cálcio. Mas em todos os casos, foi observada uma área central onde o tecido ósseo se mostrava menos espesso e às vezes interrompido por um feixe de tecido conjuntivo fibroso. Aos 90 e 180 dias, havia ocorrido em ambos os períodos, o completo fechamento da área do defeito por tecido ósseo de arranjo compacto, trabéculas ósseas espessas e espaços medulares normais.

Esses resultados estão de acordo com os de outros estudos em que foram utilizados fêmures de carneiro, períodos de 8 semanas,(WALSH et al. ${ }^{115}$, 2003), tíbia de coelho, período de 4 semanas(PARSONS et al. ${ }^{79}, 1988$ ), fêmures de coelho, período de 8 semanas (AL RUHAIMI ${ }^{2}$, 2000).e alvéolos dentais de cães, período de 200 dias (SANTOS ${ }^{96}, 2000$ ). 
Porém, ao contrário dos trabalhos acima citados, ELKINS ; JONES ${ }^{32}$, em 1988, observaram nos seus estudos em fêmures de cães, que no grupo controle (coágulo) o reparo foi inferior aos observados nos grupos experimentais, tratados com SC, SC+osso cortical autógeno e somente osso cortical autógeno. 
7

Conclusões 


\section{CONCLUSÕES}

De acordo com os resultados obtidos neste estudo, pode-se concluir que:

1. Os defeitos ósseos tratados com o sulfato de cálcio mostraram ocorrência de neoformação óssea em todos os grupos estudados, indiferente da marca comercial do produto utilizado.

2. No grupo controle preenchido somente com o coágulo sangüíneo a ocorrência de neoformação óssea foi mais intensa do que nos grupos experimentais, em todos períodos de avaliação. 
Referências Bibliográficas

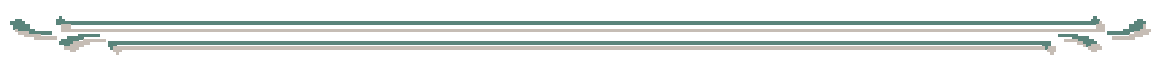




\section{REFERÊNCIAS BIBLIOGRÁFICAS *}

1. AL RUHAIMI, K.A. Closure of palatal defects without a surgical flap: An experimental study in rabbits. J Oral Maxillofac Surg, v.59, n.11, p.1319-25, Nov. 2001.

2. AL RUHAIMI, K.A. Effect of adding resorbable calcium sulfate to grafting materials on early bone regeneration in osseus defects in rabbits. Int $\mathbf{J}$ Oral Maxillofac Implants, v.15, n.6, p.859-64, 2000.

3. AL RUHAIMI, K.A. Effect of calcium sulphate on the rate of osteogenesis in distracted bone. Int J Oral Maxillofac Surg, v.30, n.3, p.228-33, June 2001.

4. ALHADAINY, H.A. Use of a hydroxylapatite-based material and calcium sulfate as artificial floors to repair furcal perforation. Oral Surg Oral Med Oral Pathol, v.86, n.6, p.723-9, Dec. 1998.

5. ALHADAINY, H.A. ; HIMEL, V.T. An in vitro evaluation of plaster of Paris barriers used under amalgam and glass ionomer to repair furcation perforation. J Endod, v.20, n.9, p.449-52, Sept. 1994.

\footnotetext{
* Normas recomendadas para uso no âmbito da Universidade de São Paulo, com base no documento "Referências Bibliográficas: exemplos", emanado no Conselho Supervisor do Sistema Integrado de Bibliotecas da USP, em reunião de 20 de setembro de 1990.
} 
6. ANSON, D. Calcium sulfate: a four year observation of its use as a resorbable barrier in guided tissue regeneration of periodontal defects. Comp Cont Ed Dent, v.17, n.8, p.895-9, Sept. 1996.

7. ANUSAVICE, K.J. Phillips Materiais dentários. 10. a ed. Rio de Janeiro, Guanabara Koogan, 1998. Cap. 9, p.111-24.

8. APAYDIN, E.S. ; TORABINEJAD, M. The effect of calcium sulfate on hard tissue healing following periradicular surgery. J Endod, v.28, n.3, p.242, March 2002.

9. BAHN, S.L. Plaster: a bone substitute. Oral Surg Oral Med Oral Pathol, v.21, n.5, p.672-81, May 1966.

10. BAI, M.H.; LIU, X.Y.; GE, B.F. An implant of a composite of bovine bone morphogenetic protein and plaster of Paris for treatment of femoral shaft non-union. Int Surg, v.4, p.390-2, 1996.

11. BEESON, W.H. Plaster of Paris as an alloplastic implant in the frontal sinus. Arch Otolaringol, v.107, p.664-9, Nov. 1981.

12. BELL, W.H. Resorption characteristics of bone and plaster of Paris. $\mathbf{J}$ Dent Res, v.39, n.4, p.727-31, 1960.

13. BENOIT, M.A. et al. Antibiotic loaded plaster of Paris implants coated with polylactide co-glycolide as a controlled release delivery system for the treatment of bone infections. Int Orthop, v.21, n.6, p.403-8, Jan. 1998

14. BLAHA, J.D. Calcium sulfate bone void filler. Orthopedics, v.9, p.10179, 1998. 
15. BOYNE, P.J. Treatment of oral bony defects in man with anorganic heterogenous bone. Oral Surg Oral Med Oral Pathol, v.11, n.3, p.322-9, Mar. 1958.

16. CALHOUN, N.R. ; NEIDERS, M.E. ; GREENE JR, G.W. Effects of plaster of Paris implant in surgical defects of mandibular alveolar process of dogs. J Oral Surg, v.25, n.2, p.122-8, Mar. 1967.

17. CANO, J.M. Sulfato de cálcio associado à gentamicina como material de substiuição óssea. Rev Bras Ortop, v.34, n.5, p.355-60, maio 1999.

18. CARNEIRO, E. Análise microscópica descritiva do efeito do tamanho das partículas da matriz de osso medular bovino desmineralizado na reparação de defeitos ósseos em fêmures de coelho. Bauru, 2003. 68p. Dissertação (Mestrado) - Faculdade de Odontologia de Bauru, Universidade de São Paulo.

19. CHOGLE, S. ; MICKEL, A.K. An in vitro evaluation of the antibacterial properties of barriers used in guided tissue regeneration. J Endod, v.29, n.1, p.1-3, Jan. 2003.

20. CLOKIE, C.M.L. et al. Closure of critical sized defects with allogenic and alloplastic bone substitutes. J Craniofac Surg, v.13, n.1, p.111-21, Jan. 2002.

21. COETZEE, A.S. Regeneration of bone in the presence of calcium sulfate. Arch. Otolaryngol, v.106, p.405-9, 1980.

22. CONCANNON,M.J. ; BOSCHERT,M.T. ; PUCKETT,C.L. Bone induction using demineralized bone in the rabbit femur: a long term study. Plast Reconstr Surg, v.99, n.7, p.1983-8, June 1997. 
23. CONNER, H.D. Bone grafting with a calcium sulfate barrier after root amputation. Comp Cont Ed Dent, v.17, n.1, p 42-8, Jan. 1996.

24. COURI, C. Medical grade calcium sulfate hemihydrate versus expanded polytetrafluorethylene in the treatment of mandibular class II furcation. J Periodontol, v.28, n.11, p.1352-9, Nov. 2002.

25. DAHLIN, C. A origem científica da regeneração óssea guiada. In: BUSER, D. ; DAHLIN, C. ; SCHENK, R.K. Regeneração óssea guiada em implantodontia. São Paulo, Quintessence, 1996. Cap.2, p.31-48.

26. DAHNERS, L.E. ; FUNDERBUK,C.H. Gentamicin loaded plaster of Paris, as a treatment of experimental osteomyelitis in rabbits. Clin Orthop, v.219, p.278-82, 1987.

27. DAMIEN, C.J. et al. Investigation of a hydroxylapatite and calcium sulfate composite supplemented with an osteocondutive factor. J Biomed Mater Res, v.24, n.6, p.639-54, Jun.1990.

28. DE LEONARDIS, D. ; PECORA, G. Augmentation of the maxillary sinus with calcium sulfate: one year clinical report from a prospective longitudinal study. Int J Oral Maxillofacial Implants, v.14, n.16, p.869-78, 1999.

29. DE LEONARDIS, D. ; PECORA, G. Prospective study on the augmentation of the maxillary sinus with calcium sulfate: histological results. J Periodontol, v.71, n.6, p.940-7, June 2000.

30. DREESMAN, H. Ueber knochenplombierung. Beitr Clin Chir, v.9, p.804-10, 1892 apud Peltier, L.F. The use of plaster of Paris to fill defects in bone. Clin Orthop, v. 21, p.1-31, 1961. 
31. EDBERG, E. Some experiences of filling osseus cavities with plaster. Acta Chir Scandinav, 1930 apud Peltier, L.F. The use of plaster of Paris to fill defects in bone. Clin Orthop, v.21, p.1-31, 1961.

32. ELKINS, A.D. ; JONES, L.P. The effects of plaster of Paris and autogenous cancellous bone on the healing of cortical defects in the femurs of dogs. Vet Surg, v.17, n.2, p.71-8, 1988.

33. FRAME, J.W. A composite of porous calcium sulphate dihydrate and cyanocrylate as a substitute for autogenous bone. J Oral Surg,v.38, p.251-6, April 1980.

34. FRAME, J.W. Porous calcium sulphate dihydrate as a biodegradable implant in bone. J Dent, v.3, p.177-87, 1975.

35. FRAME, J.W. ; BROWNE, R.M. Ridge augmentation using solid and porous hydroxylapatite particles with and without autogenous bone or plaster. J Oral Maxillofac Surg,v.45, n.9, p.771-7, 1987.

36. GITELIS, S. ; PIASECKI, P. ; TURNER, T. Use of calcium sulfate-based bone graft substitute for benign bone lesions. Orthopaedics,v.2, p.162-6, 2001.

37. GOLDMAN, R.S. et al. Tratamento cirúrgico das lesões do periápice com implantes de sulfato de cálcio. Rev Bras Cir Implant, v.7, n.25, p.55-8, 2000.

38. GRANJEIRO, J.M. et al. Hidroxiapatita para o uso clínico: caracterização físico-quiímica. Rev Gaúcha Odontol, v.40, p.130-4, 1992. 
39. GUARNIERI, R. ; BOVI, M. Maxillary sinus augmentation using prehardened calcium sulfate: a case report. Int J Period Rest Dent, v.22, n.5, p.503-8, 2004.

40. HADJIPAVLOU, A.G. ; SIMMONS, J.W. ; YANG, J. Plaster of Paris as an osteoconductive material for interbody vertebral fusion in mature sheep. Spine, v.1, p.10-5, 2000.

41. HANKER, J. et al. Plaster of Paris as a scaffold for incorporation of hydroxylapatite. J Dent Res, abst 1385, v.63, p.325, 1984.

42. HOGSET, O. ; BREDBERG, G. Plaster of Paris: thermal properties and biocompatibility. Acta Otolarungol, v.101, p.445-52, 1986.

43. JAMALI, A. et al. Hydroxyapatite/calcium carbonate(HA/CC) vs. plaster of Paris: a histomorphometric and radiografic study in a rabbit tibial defect model. Calcif Tissue Int, v.71, n.2, p.172-8, Jun. 2002.

44. JANTARAT, J. ; DASHPER, S. ; MESSER, H.H. Effect of matrix placement on furcation perforation repair. J Endod, v.25, n.3, p.192-6, Mar. 1999.

45. JENSEN, S.S. et al. Tissue reactions and material characteristics of four bone substitutes. Int J Oral Maxillofac Implants, v.11, n.1, p.55-66, Jan./Feb. 1996.

46. JUNQUEIRA, L.C. ; CARNEIRO, J. Histologia básica. 9.ed. Rio de Janeiro, Guanabara Koogan, 1999. p.111-28.

47. KANNIA, R.E. et al. Addition of sealant to ceramic promotes bone repair: long term study in rabbit femoral defect model. J Biomed Mater Res, v.43, n.1, p.38-45, 1998 
48. KELLY, C.M. et al. The use of a surgical grade calcium sulfate as a bone graft substitute: results of a Multicenter Trial. Clin Orthop Rel Res, n.382, Jan 2001.

49. KIM, S.G. ; KIM, H.K. ; LIM, S.C. Combined implantation of particulate dentine, plaster of Paris, and a bone xenograft (Bio-Oss) for bone regeneration in rats. J Craniomaxillofac Surg, v.29, n.5, p.282-8, Oct. 2001.

50. KIM, C.K. et al. Effect of a calcium sulfate implant with calcium sulfate barrier on periodontal healing in 3-wall intrabony defects in dogs. $\mathbf{J}$ Periodontol, v.69, p.982-8, 1998.

51. KIM, C.K. et al. Periodontal repair in intrabony defects treated with a calcium sulfate implant and calcium sulfate barrier. J Periodontol, v.69, p.1317-24, 1998.

52. KIM, S.G. et al. Use of particulate dentin-plaster of Paris combination with/without platelet-rich plasma in the treatment of bone defects around implants. Int J Oral Maxillofac Implants, v.17, n.1, p.86-94, Jan./Feb. 2002.

53. KOFMANN, S. Gips als Plombenmaterial. Zentralbl. Chir, v.52, p.18178, 1925 apud Peltier, L.F. The use of plaster for Paris to fill defects in bone. Clin Orthop, v.21, p.1-31, 1961.

54. KOVACEVIC, B. Ein Beitrag zum problem der hämatogenen osteomyelitis. Deutsche Ztschr Chir, v.276, p.432-43, 1953 apud Peltier, L.F. The use of plaster of Paris to fill defects in bone. Clin Orthop, v.21, p.1-31, 1961. 
55. LEBOURG, L. ; BIOU, C. The imbedding of plaster of Paris in surgical cavities of the jaws. Sem Hosp Paris, n.37, p.1195-7, 1961.

56. LEME, J.J. ; ROSSI JR, R. ; VILLA, N. Análise do potencial osteogênico do plasma rico em plaquetas no reparo de cavidades ósseas - estudo histológico em cães. Rev Paul Odont, v.26, n.3, p.17-22, maio/junho, 2004

57. LEWIS, R.D. et al. Composite hydroxuapatite/plaster implants for complex endodontic defects and lesions. Mat Res Soc Proc, v.110, p.301-10, 1989.

58. LINDLHEN, J. et al. Tratado de periodontia clínica e ilmplantologia oral. Rio de Janeiro, Guanabara Koogan, 2000.

59. MACNEILL, S.R. et al. In vivo comparison of synthetic osseus graft materials. J Clin Periodontol, v.25, n.4, p.239-45, 1999.

60. MARAGOS, P. et al. Comparison of three methods using calcium sulfate as a graft/barrier material for the treatment of class mandibular molar furcation defects. Int J Period Rest Dent, v.22, n.5, p.493-501, 2002.

61. MARX, R.E. Clinical application of bone biology to mandibular and maxilary reconstruction. Clin Plast Surg, v.21, n.3, p.377-92, July 1994.

62. MARX, R.E. ; GARG, A. K. Bone structure, metabolism and physiology: Its impact on dental implantology. Implant Dent, v.7, n.4, p.267-76, 1998. 
63. MARZOLA, C. et al. Implantes de gesso Paris modificado em cavidades cirúrgicas. Estudo clínico. Rev Odonto Ciência, v.6, n.12, p.39-61, dez. 1991.

64. MAZE, G.I. et al. Bone regeneration capacity of a combination calcium sulfate - demineralized freeze dried bone allograft. J Periodontol, v.65, n.10, p.983-9, Oct. 1994.

65. MCKEE, J.C. ; BAILEY, B.J. Calcium sulfate as a mandibular implant. Otolaryngol Head Neck Surg, v.92, p.277-86, 1984.

66. MELLONIG, J.T. Human histologic evaluation of bovine derived bone xenograft in the treatment of periodontal osseus defects. Int $\mathbf{J}$ Period Rest Dent, v.20, n.1, p.19-29, 2000.

67. MELO, L.G.N. Avaliação do processo de reparo ósseo em cavidades cirúrgicas preenchidas com partículas de vidro bioativo associadas ou não à barreira de sulfato de cálcio: estudo histomorfométrico em tíbias de rato. Araçatuba, 2003. 169p. Dissertação (Mestrado) - Faculdade de Odontologia de Araçatuba, UNESP.

68. MITTAL, M. ; CHANDRA, S. An evaluation of plaster of Paris barriers used under various materials to repair furcation perforation. In vitro study. J Endod, v.25, n.5, p.385-8, May 1999.

69. MOUSSET, B. et al. Biodegradable implants for potential use in bone infections: an in vitro study of antibiotic loaded calcium sulfate. Int Orthop, v.19, n.3, p.157-61, 1995. 
70. MURASHIMA, Y. et al. Calcium sulphate as a bone substitutes for various osseus defects in conjuntion with apicectomy. Int Endod J, v.35, p.768-74, Sept. 2002.

71. NAJJAR, T.A. ; LERDRIT, W. ; PARSONS, J.R. Enhanced osseointegration of hydroxylapatite implant material. Oral Surg Oral Med Oral Pathol, v.71, n.1, p.9-15, Jan. 1991.

72. NARY FILHO, H. ; OKAMOTO, T. Avaliação da biocompatibilidade de implantes de Hapset $^{R}$ (hidroxiapatita associada ao sulfato de cálcio) em feridas de extração dental. Estudo histológico em ratos. Rev. FOB, v.14, n.1/2, p.55-64, jan./jul. 1996.

73. NIEDERAUER, G.G. ; SLIVKA, M.A. ; LEATHERBURY, N.C. Evaluation of multiphase implants for repair of focal osteochondral defects in goats. Biomaterials, v.24, p.2561-74, 2000.

74. NIELSON, A. Filling of sterile end infected bone cavities by means of plaster of Paris. Acta Chir Scandinav, v.91, p.17-27, 1944 apud Peltier, L.F. The use of plaster of Paris to fill defects bone. Clin Orthop, v.21, p.1-31, 1961.

75. NIKULIN, A. ; LJUBOVIC, E. Der gipsstift in der experimentellen knochenregeneration. Acta Med Iugoslav, v.10, p.17-27, 1956 apud Peltier, L.F. The use of plaster of Paris to fill defects bone. Clin Orthop, v.21, p.1-31, 1961.

76 ORSINI, M. Comparison of calcium sulfate and autogenous bone graft to bioabsorbable membranes plus autogenous bone graft in the treatment of intrabony periodontal defects: a split-mouth study. J Periodontol, v.72, n.3, p.296-302, Mar. 2001. 
77. ORSINI, G. et al. Bone defect healing with calcium sulfate particles and cement: an experimental study in rabbit. J Biomed Mater Res, v.15, n.68B(2), p.199-208, Feb. 2004.

78. PARSONS, J.R. ; RICCI, J.L. ; ALEXANDER, H. Osteoconductive composite grouts for orthopedic use. Ann NY Acad Sci, v.523, p.190-207, 1988.

79. PAYNE, J.M. Migration of human gingival fibroblasts over guided tissue regeneration barrier materials. J Periodontol, v.67, n.3, p.236-44, 1996.

80. PECORA, G. Bone regeneration with a calcium sulfate barrier. Oral Surg Oral Med Oral Pathol, v.84, n.4, p.424-9, 1997.

81. PECORA, G. Short-term healing following the use of calcium sulfate as a grafting material for sinus augmentation: a clinical report. Int $\mathbf{J}$ Oral Maxillofac Implants, v.13, n.6, p. 866-73, 1998.

82. PECORA, G. The use of calcium sulphate in the surgical treatment of a "through and through" periradicular lesion. Int Endod J, v.34, n.3, p.189-197, 2001.

83. PECORA, G. et al. Barrier membrane techniques in endodontic microsurgery. Dent Clin North Am, v.41, n.3, p.585-601, July 1997.

84. PECORA, G. et al. O uso do sulfato de cálcio em endodontia. Rev Bras Odont, v.57, n.2, p.98-100, mar./abr. 2000.

85. PELTIER, L.F. The use of plaster of Paris to fill large defects in bone. Am J Surg, v.97, p.311-5, 1959. 
86. PELTIER, L.F. The use of plaster of Paris to fill defects in bone. Clin Orthop, v.21, p.1-31, 1961.

87. PELTIER, L.F. ; LILLO, R. The substitution of plaster of Paris rods for portions of the diaphysis of the radius in dogs. Surg Forum, v.6, p.556-8, 1956.

88. PELTIER, L.F. et al. The use of plaster of Paris to fill defects in bone. Ann Surg, v.146, p.61-9, 1957.

89. PETROVA, A. Gipsfüllung von knochenhöhlen beii osteomyelitis. Zentralorg. ges. Chir, v.43, p.885, 1928 apud Peltier, L.F. The use of plaster of Paris to fill defects in bone. Clin Orthop, v.21, p.1-31, 1961.

90. PINTO SIBONI, A. et al. Experiencia con el sulfato de calcio como sustituto de injertos óseos. Rev. Venez Cir Ortop Traumatol, v.33, n. 1, p.30-4, mar. 2001.

91. RADENTZ, W.R. ; COLLINGS, C.K. The implantation of plaster of Paris in the alveolar process of the dog. J Periodontol, v.36, p.357-64, 1965.

92. RAFTER, M. et al. Evaluation of healing with use of an internal matrix to repair furcation perforations. Int Endod J, v.35, n.9, p.775-83, Sep. 2002.

93. ROSEMBLUM, S.F.; FRENKEL, S.; RICCI, S.R.. Diffusion of fibroblasts growth factor from a plaster of Paris carrier. J Appl Biomater, v.p. 6772, 1993 
94. ROSEN, P.S. ; REYNOLDS, M.A. Polymer-assisted regenerative theraphy: case report of 22 consecutively trested priodontal defects with a novel combined surgical approach. J Periodontol, v.70, n.5, p.554-61, May 1999.

95. SANTOS, F.A. Implantes de biomateriais em alvéolos dentais. Estudo hisstológico em cães. Araraquara, 2000. 152p. Tese (Doutorado) - Faculdade de Odontologia de Araraquara, UNESP.

96 SATO, S. ; KOSHINO, T. ; SAITO, T. Osteogenic response of rabbit to hydroxylapatite particle-plaster of Paris mixture. Biomaterials, v.19, n.20, p.1895-1900, Oct. 1998.

97. SCHENK, R.K. Regeneração óssea: bases biológicas. In: BUSER,D. ; DAHLIN,C. ; SCHENK, R.K. Regeneração óssea guiada em Implantodontia. São Paulo, Quintessence, 1996. Cap.3, p.49-100.

98. SETYA, A.B. ; BISSADA, N.F. Clinical evaluation of the use of calcium sulfate in regenerative periodontal surgery for the treatment of class III furcation involvement. Periodont Clin Investig, v.21, n.2, p.5-14, 1999.

99. SHAFFER, C.D. ; APP, G.R. The use of plaster of Paris in treating infrabony periodontal defects in humans. J Periodontol, v.42, n.11, p.685-90, 1971.

100. SNYDERS JR, R.V. ; EPPLEY, B.L. ; KRUKOWSKI, M. Enhancement of repair in experimental calvarial bone defects using calcium sulfate and dextran beads. J Oral Maxillofac Surg, v.5, p.517-24, 1993. 
101. SOARES DOS SANTOS, I. S. Caracterização de alguns gessos do mercado nacional para aplicação na construção civil. São Paulo, 1983. 141p. Dissertação (Mestrado) - Escola Politécnica, Universidade de São Paulo.

102. SOTTOSANTI, J.S. Calcium sulfate: a valuable addition to the implant/bone regeneration complex. Dent Implantol Update, v.4, p.25-9, 1997

103. SOTTOSANTI, J.S. Calcium sulfate is a safe, resorbable barrier adjunt to implant surgical procedures. Dent Implantol Update, v.9, p.6973, 1993.

104. STACHOW, V. Versuch über knochenplombierung bei hohlenförmigen defekten des knochens. Beitr Klin Chir, v.12, p.389-408, 1894 apud Peltier, L.F. The use of plaster of Paris to fill defects bone. Clin Orthop, v.21, p.1-31, 1961.

105. STROCCHI, R. et al. Bone regeneration with calcium sulfate: evidence for increased angiogenesis in rabbits. J Oral Implant, v.28, n.6, p.273-8, 2002.

106. STEPHAN, E.B. et al. Anorganic bovine boné supports osteoblastic cell attachment and proliferation. J Periodontol, v.70, n.4, p.364-99, 1999.

107. SU-GWAN, K. ; HAK-KYUN, K. ; SUNG-CHUI, L. Combination implantation of particulate dentine, plaster of Paris, and a bone xenograft (Bio-Oss) for bone regeneration in rats. $\mathbf{J}$ Craniomaxillofac Surg, v.29, n.5, p.282-8, Oct. 2001. 
108. TURNER, T.M. ; URBAN, R.M. ; GITELIS, S. Efficacy of calcium sulfate, a synthetic bone graft material in healing a large canine medullary defect. Trans Orthop Res Soc, v.24, p.522-6, 1999.

109. TURNER, T.M. et al. Radiographic anf histologic assessment of calcium sulfate in experimental animal models and clinical use as a resorbable bone-graft substitute, a bone-graft expander, and a method for local antibiotic. J Bone Joint Surg, v.83-A, suppl 2, part 1, p.8-18, 2001.

110. VENTURINI, M.S. ; VENTURINI, M.D. ; HETESSY, L.R. Sulfato de cálcio como membrana. Rev Odontol Unicid, v.11, n.2, p.131-6, jul./dez. 1999.

111. VICTOR, J.O. et al. Implante de gesso de Paris em alvéolos dentais. Estudo histológico em ratos. Rev Fac Odont Araçatuba, v.4, n.1, p.71-5, 1975.

112. YAMASAKI, Y. et al. Response of the femoral muscle to an implant of a composite of bone morphogenetic protein and plaster of Paris. Clin Orthop Re Res, v.234, p.240-9, Sept. 1988.

113. YOSHIKAWA, G. et al. Guided bone regeneration (GBR) using membranes and calcium sulphate after apicectomy: a comparative histomorphometrical study. Int Endod J, v.35, n.3, 255-63, Mar. 2002.

114. WALSH, W.R. et al. Response of calcium sulfate bone substitute in a confined cancellous defects. Clin Orthop, v.406, p.228-36, Jan. 2003. 
115 WILKINS, R.M. ; KELLY, C.M. ; GIUSTI, D.E. Bioassayed demineralized bone matrix and calcium sulfate: use in bone-grafting procedures. Ann Chir Gynaeco, v.88, p.180-5, 1999.

116. WILLIANS, D.F. Definitions in biomaterials. New York, Elserver, 1987. In Tunes, U.R. Atualização em periodontia e implantodontia. São Paulo, Artes Médicas, 1999.

117. WIRSCHING, F. Calcium sulfate. In: Encyclopedia of industrial chemistry. $5^{\text {th }}$ ed. Fritz Ullmann, Deerfield Beach, USA, 1993. v.4A, p .555-81. 
Abstract 


\section{ABSTRACT \\ Microscopy evaluation of tissue reaction to surgicals cavities on the rabbits femurs filled with calcium sulfate}

The aim of this study was to evaluate histologically the calcium sulfate Merck (Brazil), Surgiplaster (Italy), Capset ( USA) in surgically created defects at rabbits femur. Twenty male rabbits New Zealand were used and on each femur distal epiphise, two surgical bone defects were created of 5 $\mathrm{mm}$ in diameter by $8 \mathrm{~mm}$ in depth using Dentoflex n. ${ }^{0} 3$ trefin bur. 24 defects were filled with the calcium sulfate di-hydrated (Merck) - experimental group 1, 24 defects with Capset ( Lifecor-USA) - experimental group 2, 24 defects with Surgiplaster ( Classimport Italy) - experimental group 3 and 8 defects with blood clot were used like control group. The rabbits of each group were sacrified in postoperative period of 30,60, 90 and 180 days after surgeries. Therafter, the epiphises were collected and fixed. After this, the epiphises were descalcified with Morse solution and embedded in parafin. Semi serial $6-\mu \mathrm{m}$ thick sections were obtained, stained with hematoxylin and eosin and examined on light microscope. In this present study, the microscope evaluation of defects bone treated with the calcium sulfate revealed that all experimental groups exhibit new bone formation indifferent of commercial trademark. The microscope analysis of control group that filled with blood clot showed that repair process was better than all experimental groups in whatever evaluation periods. 